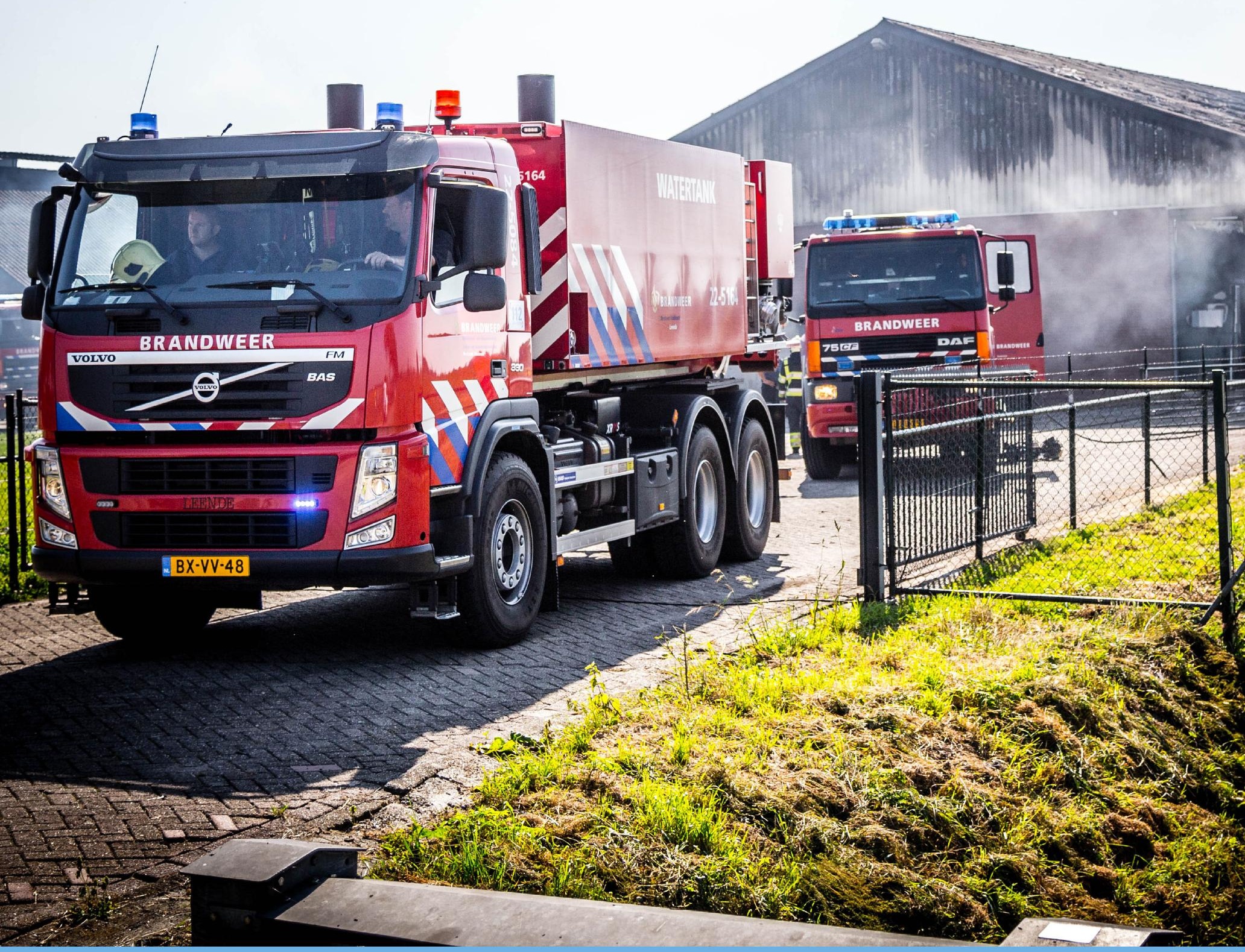

Evaluatie Actieplan Stalbranden 2012-2016

Martien Bokma-Bakker, Sjoerd Bokma, Hilko Ellen, René Hagen, Charlotte van Ruijven 



\section{Evaluatie Actieplan Stalbranden 2012-2016}

Martien Bokma-Bakker ${ }^{1}$, Sjoerd Bokma ${ }^{1}$, Hilko Ellen ${ }^{1}$, René Hagen ${ }^{2}$, Charlotte van Ruijven ${ }^{2}$

1 Wageningen Livestock Research

2 Instituut Fysieke Veiligheid

Dit onderzoek is uitgevoerd door Wageningen Livestock Research in samenwerking met Instituut Fysieke Veiligheid, in opdracht van en gefinancierd door het Ministerie van Economische Zaken, in het kader van het Beleidsondersteunend onderzoek thema 'Dierenwelzijn' (projectnummer BO-20-008-039)

Wageningen Livestock Research

Wageningen, juli 2017

Rapport 1035 
Bokma-Bakker, M.H., S. Bokma, H.H. Ellen, R.R. Hagen, C. van Ruijven, 2017. Evaluatie Actieplan Stalbranden 2012-2016. Wageningen Livestock Research, Rapport 1035.

Samenvatting NL Op verzoek van ministerie van Economische Zaken en LTO Nederland is een evaluatie uitgevoerd van het Actieplan Stalbranden 2012-2016. Er is ingeschat welk effect de binnen het Actieplan ingezette activiteiten hebben (gehad) op de brandveiligheid voor dieren in veestallen en welk vervolg op het Actieplan zinvol kan zijn.

Summary UK Commissioned by Ministry of Economic Affairs and LTO Nederland, the Dutch Action Plan on Barn Fires 2012-2016 is evaluated. The impact of the activities initiated within the action plan on fire safety for animals in barns is assessed and recommendations are given for relevant activities that fit within a continuation of the action plan.

Dit rapport is gratis te downloaden op http://dx.doi.org/10.18174/418937 of op www.wur.nl/livestock-research (onder Wageningen Livestock Research publicaties).

\section{(C) 2017 Wageningen Livestock Research}

Postbus 338, 6700 AH Wageningen, T 03174839 53, E info.livestockresearch@wur.nl, www.wur.nl/livestock-research. Wageningen Livestock Research is onderdeel van Wageningen University \& Research.

Wageningen Livestock Research aanvaardt geen aansprakelijkheid voor eventuele schade voortvloeiend uit het gebruik van de resultaten van dit onderzoek of de toepassing van de adviezen.

Alle rechten voorbehouden. Niets uit deze uitgave mag worden vermenigvuldigd en/of openbaar gemaakt worden door middel van druk, fotokopie, microfilm of op welke wijze dan ook zonder voorafgaande toestemming van de uitgever of auteur.

De certificering volgens ISO 9001 door DNV onderstreept ons kwaliteitsniveau. Op als onze onderzoeksopdrachten zijn de Algemene Voorwaarden van de Animal Sciences Group van toepassing. Deze zijn gedeponeerd bij de Arrondissementsrechtbank Zwolle. 


\section{Inhoud}

$\begin{array}{ll}\text { Woord vooraf } & 5\end{array}$

$\begin{array}{ll}\text { Managementsamenvatting } & 6\end{array}$

$\begin{array}{llr}1 & \text { Inleiding } & 11\end{array}$

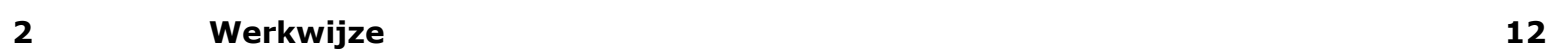

$3 \quad$ Activiteiten Actieplan samengevat $\quad 15$

$4 \quad$ Stalbranden en oorzaken $\quad 17$

4.1 Aantal stalbranden en dierlijke slachtoffers 2012-2016 17

4.2 Oorzaken van stalbranden $\quad 18$

$\begin{array}{llr}5 & \text { Resultaten interviews } & 21\end{array}$

5.1 Over het ontstaan van brand $\quad 21$

5.2 Over snelle detectie $\quad 23$

$\begin{array}{lll}5.3 & \text { Over branduitbreiding } & 24\end{array}$

$\begin{array}{lll}5.4 & \text { Over blussen } & 25\end{array}$

5.5 Over evacuatie en/of snelle euthanasie van dieren $\quad 26$

5.6 Over grote brandcompartimenten $\left(>2.500 \mathrm{~m}^{2}\right) \quad 27$

$\begin{array}{lll}5.7 & \text { Over houdingsveranderingen } & 27\end{array}$

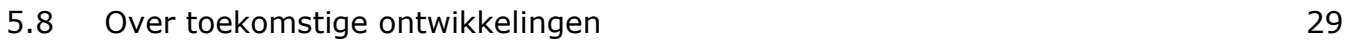

5.9 Over de rol van het Actieplan $\quad 30$

$6 \quad$ Resultaat internetenquête onder veehouders $\quad 31$

7 Ontwikkelingen binnen sectoren $\quad 36$

7.1 Verwacht vervangingsritme nieuwbouw/renovatie 36

$\begin{array}{lll}7.2 & \text { Ontwikkelingen per sector } & 37\end{array}$

$\begin{array}{lll}7.3 & \text { Ontwikkelingen in kwaliteitssystemen } & 39\end{array}$

$8 \quad$ Analyse van de bevindingen $\quad 41$

9 Conclusies $\quad 49$

$9.1 \quad$ Brandveilige bedrijfsvoering $\quad 49$

$\begin{array}{lll}9.2 & \text { Brandveilige stallen } & 50\end{array}$

9.3 Stalbranden en oorzaken $\quad 54$

10 Advies $r 55$

$\begin{array}{ll}\text { Literatuur } & \mathbf{5 8}\end{array}$

Bijlage 1 Voortgangsrapportage Actieplan Stalbranden 2012-2017 59

$\begin{array}{lll}\text { Bijlage } 2 & \text { Vragenlijst interviews } & 66\end{array}$

$\begin{array}{lll}\text { Bijlage } 3 & \text { Vragenlijst internetenquête veehouders } & 68\end{array}$

$\begin{array}{lll}\text { Bijlage } 4 & \text { Resultaten internetenquête veehouders } & \mathbf{7 0}\end{array}$

$\begin{array}{lll}\text { Bijlage } 5 & \text { Sectorspecifieke ontwikkelingen } & 73\end{array}$

$\begin{array}{lll}\text { Bijlage } 6 & \text { Interpretatie regelgeving } & 77\end{array}$

Bijlage 7 Kostenoverzicht brandveiligheidsmaatregelen (2012) 79 


\section{Woord vooraf}

Voor u ligt een evaluatie van het Actieplan Stalbranden 2012-2016. De initiatiefnemers hebben het Actieplan opgesteld vanuit de wens om dieren beter te beschermen tegen brand en het aantal stalbranden en het aantal dieren dat omkomt bij een stalbrand fors te verminderen. Aan Wageningen Livestock Research en Instituut Fysieke Veiligheid is gevraagd om in te schatten welk effect de in de periode 2012-2016 ingezette acties hebben (gehad) en welke follow up van het Actieplan zinvol en haalbaar zou kunnen zijn.

De basis voor de evaluatie wordt gevormd door kwalitatief onderzoek via interviews met stakeholders, een beknopte internetenquête onder veehouders, analyse van geregistreerde stalbranden en expertkennis over toekomstige ontwikkelingen. Graag wil het onderzoeksteam de vertegenwoordigers van gemeenten, brandweer, verzekeraars en bouwadviesbureaus danken voor hun constructieve medewerking aan de interviews en het grote aantal veehouders bedanken voor hun bijdrage aan de internetenquête.

Met het Actieplan Stalbranden 2012-2016 is onze optiek een goede stap gezet richting een grotere brandveiligheid voor dieren in veestallen. Wij hopen en verwachten dat het resultaat van deze evaluatie handvatten geeft om de brandveiligheid voor dieren in veestallen als follow up van het Actieplan verder te versterken.

Namens het onderzoeksteam,

Dr. J.M.J. Rebel

Hoofd afdelingen Dierenwelzijn en Diergezondheid

Wageningen Livestock Research 


\section{Managementsamenvatting}

Het Actieplan Stalbranden 2012-2016 is een initiatief van LTO Nederland, de Dierenbescherming, Brandweer Nederland, het Verbond van Verzekeraars en de Rijksoverheid. In 2015 hebben de Koninklijke Nederlandse Maatschappij voor Diergeneeskunde (KNMvD) en de Nederlandse Voedsel- en Warenautoriteit (NVWA) zich aangesloten bij het Actieplan. Het ministerie van Economische Zaken (EZ) en LTO Nederland heeft Wageningen Livestock Research (WLR) gevraagd om in samenwerking met het Instituut Fysieke Veiligheid (IFV) een evaluatie van het Actieplan uit te voeren.

In deze evaluatie zijn de volgende vragen beantwoord:

1. Wat is het effect van de ontwikkelde activiteiten geweest op:

a. brandveilige bedrijfsvoering;

b. brandveilige stallen (effecten nu en in de toekomst)?

2. Is door activiteiten binnen het Actieplan het inzicht in stalbranden en de oorzaken ervan toegenomen?

3. Welke activiteiten zijn zinvol als vervolg op het Actieplan en welke indicatie van kosten hoort daarbij?

Het onderzoek is uitgevoerd o.a. op basis van informatie die is aangeleverd door de werkgroep Actieplan Stalbranden over ingezette activiteiten in de periode 2012-2016 en de stand van zaken eind 2016, en over het aantal stalbranden en oorzaken daarvan in de genoemde periode. Er zijn interviews gehouden met gemeenten, brandweer, bouwadviesbureaus en verzekeraars over veranderingen in brandveiligheid in de afgelopen jaren, actuele knelpunten en oplossingsrichtingen, en er is een internetenquête uitgezet onder veehouders naar attitude en brandveilig handelen. (Toekomstige) ontwikkelingen binnen sectoren in relatie met brandveiligheid zijn via expertview in kaart gebracht.

\section{Conclusies in relatie met brandveilige bedrijfsvoering}

* Het bewustzijn van bepaalde typen veehouders, en vooral van schaalvergroters, met betrekking tot brandveiligheid lijkt te zijn toegenomen in de looptijd van het Actieplan (interviews, internetenquête).

* Activiteiten op het gebied van voorlichting over brandveiligheid van veestallen en de dieren daarin verdienen continue voortzetting. Brandveiligheid van stallen zal sterk onder druk blijven staan door de relatief geringe kans op stalbrand (ondanks de grote impact), de kostprijsgedreven afwegingen en de regeldruk op o.a. milieugebied, en dient mede om die reden regelmatig onder de aandacht te worden gebracht.

* Werkzaamheden zijn nog steeds belangrijke oorzaken van stalbrand. Voorlichting over brandveilig werken dient zich niet alleen te richten op veehouders, maar ook op professionele bedrijven die (brandgevaarlijke) werkzaamheden in en aan stallen uitvoeren (installateurs, dakdekkers, ...).

* Praktijknetwerken in de varkens-, pluimvee- en rundveehouderij hebben binnen het Actieplan Stalbranden een aantal praktische en waardevolle oplossingen aangedragen voor o.a. brandveiliger werken en kunnen, evenals studieclubs, ook in een vervolg een relevante rol spelen.

* Realisatie van opname van brandveiligheid voor dieren in veestallen in het reguliere agrarische onderwijs is belangrijk om toekomstige veehouders en dierverzorgers bewust te maken van het belang ervan en te voorzien van de benodigde kennis en tools.

\section{Conclusies in relatie met brandveilige stallen}

* De overall kans op brand met dierlijke slachtoffers bij nieuwbouw na 1-4-2014 is in gunstige zin veranderd. Dit hangt samen met de nieuwe voorschriften in het Bouwbesluit over compartimentering van technische ruimten en de hogere brandklasse van constructie/- 
isolatiematerialen. Het hangt ook samen met keuringseisen die verzekeraars en/of gemeenten stellen aan elektrische apparaten bij oplevering van de nieuwbouw en de eisen van verzekeraars voor periodieke keuring na ingebruikname ervan. Er wordt bij nieuwbouw enige toename gezien in branddetectie in de technische ruimte en men lijkt alerter te zijn op de aanwezigheid van handblusmiddelen.

* Voor bestaande stallen in de verschillende sectoren is de brandveiligheid in de afgelopen jaren in geringe mate verbeterd. Dat hangt vooral samen met de gunstige ontwikkeling die op gang is gekomen in periodieke keuring van elektrische apparaten in de verschillende sectoren, m.n. vanwege eisen in het kader van de brandverzekering.

* Er zijn verschillen waargenomen in interpretatie van bestaande wet- en regelgeving over brandveiligheid tussen gemeenten en tussen veiligheidsregio's; dit betreft toepassing van gelijkwaardigheid en uitbreiding van bestaande stallen. Gemeenten hebben sterk behoefte aan landelijke handvatten voor beoordeling van gelijkwaardigheid, en hopen en verwachten dat de in ontwikkeling zijnde bijlagen voor veestallen bij de NEN-normen 6060 en 6079 in de toekomst een goed beoordelingskader zullen bieden. De inhoud ervan is op dit moment nog te kort openbaar en daarmee niet in alle facetten te beoordelen in deze evaluatie.

* Gemeenten handhaven wisselend op de realisatie van brandveiligheidsaspecten bij nieuwbouw conform het vergunde bouwplan. Private toets en toezicht op de bouw door de bouwspecialisten zelf (wordt per 2018 gerealiseerd via de Wet Kwaliteitsborging voor het Bouwen) kan volgens de rijksoverheid kwaliteitsvoordelen hebben. Voorwaarden hierbij zijn dat het toezicht op toezicht (door een onafhankelijke toezichthouder) en verantwoordelijkheden en aansprakelijkheden van de private kwaliteitsborgers goed zijn geregeld.

* Milieu-inspecties door Omgevingsdiensten (frequentie 1 keer per 5-10 jaar, grote bedrijven het meest frequent) bieden in potentie een zinvolle gelegenheid om ondernemers, naast de formele milieu-inspectie, te attenderen op risico's met betrekking tot brandveiligheid.

* Koppeling van brandveiligheidsmaatregelen aan private kwaliteitssystemen zoals MDV en Beter Leven is en blijft een belangrijke ingang voor versterking van brandveiligheid, bij nieuwbouw en voor bestaande stallen. Opname van een periodieke elektrakeuring binnen de sectorbrede IKB-systemen biedt een belangrijke extra mogelijkheid om de kans op ontstaan van brand in alle stallen op korte termijn te reduceren of beperkt te houden. Voor stimuleren van brandveiligheid van alle stallen spelen naast private (sectorbrede) kwaliteitssystemen ook verzekeraars (voorwaarden in brandverzekering) een belangrijke rol.

* Het perspectief van inzet van dodingsmethoden zoals $\mathrm{CO}_{2}$-gas als -schuim (op waterbasis) voor koppelgewijze euthanasie van o.a. pluimvee in stalbrandsituaties is gering (o.a. door paniek naar verwachting veel fladderende/onrustige dieren en daarbij hoge temperaturen, waardoor het schuim minder werkzaam zal zijn). KNMvD en Brandweer Nederland hebben gezamenlijk een handreiking 'Dierenarts bij stalbrand' opgesteld, waarin een stappenplan voor de dierenarts met o.a. instructie over afstemming met de hulpdiensten is opgenomen.

* De beperkingen die aan de omvang van bouwblokken worden gesteld, zorgen er in combinatie met de toenemende schaalvergroting bij nieuwbouw voor dat nieuwe stallen aan bestaande stallen worden gebouwd of er dicht bij worden geplaatst. Restricties aan totaal bebouwd oppervlak verdient uit oogpunt van o.a. brandveiligheid de voorkeur boven restricties aan de maximale omvang van het bouwblok.

* Toekomstige ontwikkelingen binnen de verschillende_sectoren worden gekenmerkt door een afname van het aantal bedrijven en een voortzetting van de schaalvergroting. In alle sectoren is in toenemende mate sprake van automatisering in de stal. Die laat zich soms lastig concentreren in technische ruimtes. Een extra focus op brandveiligheid van technische installaties in dierverblijven is van belang.

* De voortgaande schaalvergroting pleit voor het stellen van een bovengrens aan de omvang van brandcompartimenten waarin dieren verblijven, onderbouwd via een zo objectief mogelijk inschatting van risico $=$ kans $x$ effect. Beoordeling van gelijkwaardigheid van grotere brandcompartimenten ( $>2.500 \mathrm{~m}^{2}$ ) op basis van kans op ontstaan en uitbreiding van stalbrand doet slechts ten dele recht aan het gelijk houden van de brandveiligheid voor de dieren: de kans op brand kan gelijkwaardig zijn, de impact van brand (dierlijke slachtoffers) beduidend hoger bij grote brandcompartimenten. De concept-bijlage van de NEN-norm 6060 kent een bovengrens voor de compartimentsgrootte van veestallen (afhankelijk van 
voorzieningen en diersoort). De concept-bijlage van de NEN 6079 die de maximale compartimentsgrootte van veestallen bepaalt op basis van een risicobenadering, houdt rekening met dierenleed, maar kent geen bovengrens. De inhoud van de bijlagen is op het moment van afronden van dit rapport nog pas kort openbaar en daarmee niet in alle facetten te beoordelen in deze evaluatie.

* De snelheid waarmee bestaande stallen binnen de veehouderijsectoren brandveiliger kunnen worden is (mede) afhankelijk van de vervangingsstermijnen voor ruwbouw, stalinrichtingen en installaties. Het in $\mathrm{H} 7$ aangegeven vervangingsritme laat zien dat, naast communicatie en onderwijs over brandveiligheid en brandveilig werken, investeringen in een verbeterde brandveiligheid van technische installaties (afschrijvingstermijn ca. 10 jaar) het snelst tot effect zullen leiden. Technische installaties zijn op dit moment in de meeste sectoren de belangrijkste oorzaak van het ontstaan van stalbranden.

* In de toekomst zal de beschikbaarheid van brandkranen die zijn aangesloten op het drinkwaternet, daar waar alternatieven voorhanden zijn, geleidelijk gaan verminderen. Om in die gevallen voldoende bluswatercapaciteit nabij grote veestallen beschikbaar te houden, zullen naast tankwagens van de brandweer extra voorzieningen zoals open water, bassins (bv. infiltratievijvers i.k.v. de watertoets) of grondwaterputten wenselijk zijn.

* Innovaties in brandveiliger technische installaties en stalinrichtingselementen kunnen een impuls geven aan versterking van de brandveiligheid binnen de dierlijke sectoren. De kans op praktijktoepassing wordt (aanzienlijk) vergroot als innovaties in brandveiligheid gelijker tijd operationele doelen binnen de bedrijfsvoering dienen. Het Actieplan kan dergelijke innovaties in brandveiligheid faciliteren.

\section{Conclusies m.b.t. inzicht in stalbranden en oorzaken}

Tabel A Aantal stalbranden en omgekomen dieren in de periode 2012-2016 en de kansen op stalbrand (bron: Brandweer Nederland i.s.m. Verbond van Verzekeraars en CBS Landbouwtelling)

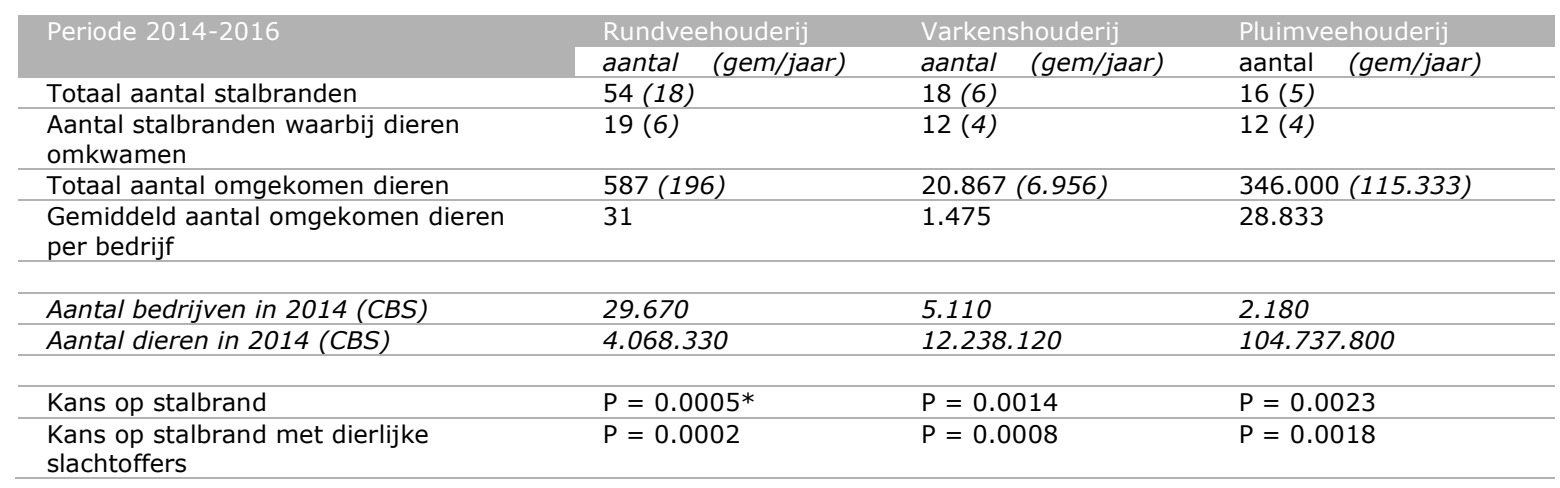

* d.i. frequentie van 5 op de 10.000 bedrijven

* Het aantal stalbranden in de periode 2014-2016 en de daarbij omgekomen dieren zijn samengevat in tabel A. De kans op stalbrand is ook in de jaren 2014-2016 relatief klein, de impact (het effect) is nog steeds groot gezien de aantallen dieren die erbij omkomen.

* Het registreren van iedere stalbrand door Brandweer Nederland (i.s.m. Bond van Verzekeraars) en onderzoek naar de oorzaak is een duidelijke verbetering ten opzichte van de situatie van voor het Actieplan. Het inzicht in het werkelijke aantal stalbranden (waar de brandweer bij is geweest) en het werkelijke aantal dierlijke slachtoffers is hierdoor verbeterd.

* Hetzelfde geldt voor het inzicht in de oorzaken van stalbranden (zie tabel B), met de kanttekening dat nog relatief veel brandoorzaken onbekend blijven (bij ruim $55 \%$ van de stalbranden). Voor zover oorzaken bekend zijn, vallen nog steeds de meeste dierlijke slachtoffers door stalbranden met een technische oorzaak (kortsluiting, oververhitting, zelfontbranding werktuigen). Daarnaast zijn in 2016 veel varkens omgekomen als gevolg van brand door menselijk handelen. Wat opvalt ten opzichte van eerdere jaren is het aantal stalbranden en dierlijke slachtoffers door blikseminslag. De verwachting is dat dit in de toekomst niet minder zal worden onder invloed van klimaatverandering, en is daarmee een (nieuw) aandachtspunt uit oogpunt van brandveiligheid. 
Tabel B Aantal omgekomen dieren naar oorzaak van stalbrand in de periode 2014-2016

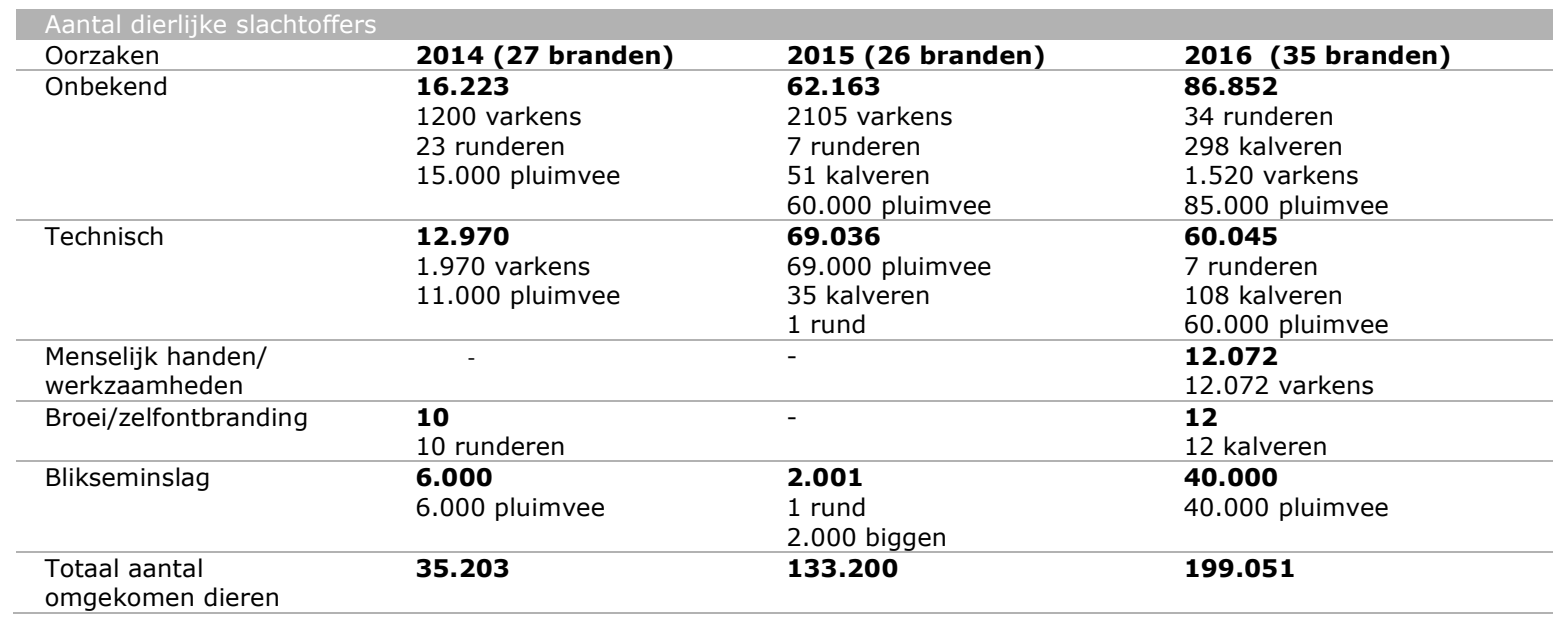

\section{Advies}

Uit de evaluatie komt naar voren dat het nuttig is om een follow up te geven aan het Actieplan Stalbranden 2012-2016. Geadviseerd wordt om de belangrijkste focus voor een follow up in de komende jaren te leggen bij de onderstaande activiteiten. Daar is de belangrijkste slag te maken in versterken van brandveiligheid voor dieren in bestaande stallen (en tevens bij nieuwbouw).

\section{Focusgebieden:}

$>$ Bevorderen van brandveiligheid van technische installaties (voer-/drinkwaterinstallatie, ventilatiesysteem, verwarmingssysteem, regelcomputer, luchtwassers, melk- en koelapparatuur, aandrijving mest-/eierbanden, aandrijving mestschuiven/-robotjes e.d.).

$>$ Bevorderen van brandveilig werken (door veehouders/dierverzorgers en professionele bedrijven zoals installateurs en dakdekkers) via voorlichting, communicatie, praktijknetwerken/ studieclubs en onderwijs

$>$ Bevorderen van alternatieve bluswatervoorzieningen op of nabij veehouderijbedrijven, daar waar de aanwezigheid van brandkranen op het drinkwaternet in de toekomst vermindert.

$>$ Onderzoeken van een redelijke bovengrens aan grote brandcompartimenten (via een zo objectief mogelijke inschatting van risico = kans $x$ effect (d.i. potentieel aantal dierlijke slachtoffers) en bevorderen van opname ervan in wet- en regelgeving. De concept-bijlagen van de NEN normen 6060 en 6079 die handelen over veestallen, zouden beide dan rekening moeten houden met dierenleed en een maximale compartimentsgrootte moeten vastleggen.

$>$ De brandveiligheid van veestallen voor mens en dier inbrengen als relevante factor voor het ruimtelijke ordeningsbeleid van provincies en gemeenten. Restricties aan totaal bebouwd oppervlak verdienen uit oogpunt van o.a. brandveiligheid de voorkeur boven restricties aan de maximale omvang van het bouwblok.

> Voortzetten en verder uitbouwen van de registratie van stalbranden en oorzaken ervan door Brandweer Nederland in samenwerking met verzekeraars. Overweeg opzet van een digitaal registratiesysteem voor stalbranden met dierlijke slachtoffers conform de werkwijze in geval van humane slachtoffers bij woningbranden.

Concrete deeladviezen met betrekking tot brandveilig werken, brandveilige stallen en inzicht in stalbranden en oorzaken binnen deze focusgebieden zijn gegeven in hoofdstuk 10 (inclusief een kostenindicatie). 


\section{$1 \quad$ Inleiding}

Het Actieplan Stalbranden 2012-2016 is een initiatief van LTO Nederland, de Dierenbescherming, Brandweer Nederland, het Verbond van Verzekeraars en de Rijksoverheid. In 2015 hebben de KNMvD en NVWA zich aangesloten bij het Actieplan. De initiatiefnemers zijn van mening dat dieren beter beschermd moeten worden tegen brand en dat het aantal stalbranden en het aantal dieren dat omkomt bij een stalbrand fors moet worden verminderd. De initiatiefnemers willen dit realiseren aan de hand van diverse activiteiten die in het Actieplan zijn opgenomen.

De looptijd van het Actieplan beslaat de periode 2012-2016. Nu de looptijd is geëindigd, hebben ministerie van Economische Zaken (EZ) en LTO Nederland namens de initiatiefnemers aan Wageningen Livestock Research (WLR) gevraagd om, in samenwerking met Instituut Fysieke Veiligheid (IFV), een evaluatie van het Actieplan uit te voeren, in te schatten welk effect ingezette acties hebben gehad en aan te geven welke follow up zinvol en haalbaar (kosteneffectief) zou kunnen zijn.

In dit rapport worden de resultaten van de evaluatie en het advies over een zinvolle follow up beschreven. Het project is uitgevoerd in de periode januari-juni 2017.

\section{Onderzoeksvragen}

Uit Actieplan Stalbranden 2012-2016 is de volgende doelstelling af te leiden:

'Dieren beter beschermen tegen de gevolgen van brand in een stal en het aantal stalbranden en het aantal dieren dat omkomt bij een stalbrand fors verminderen'

Om dit doel te bereiken zijn in het actieplan (gaandeweg) vier realisatiesporen onderscheiden:
A. Een brandveilige bedrijfsvoering
B. Brandveilige stallen voor mens en dier
C. Stimuleren van brandveilige stallen
D. Verbeterd inzicht in oorzaken van stalbranden en betere beheersbaarheid

Binnen elk realisatiespoor zijn verschillende activiteiten ingezet (zie hoofdstuk 3 ).

In het onderzoek worden de volgende vragen beantwoord:

1. Welke activiteiten hebben plaatsgevonden binnen het Actieplan Stalbranden (inventarisatie)

2. Wat is het effect van de ontwikkelde activiteiten geweest op (inschatting effect):

a. brandveilige bedrijfsvoering

b. brandveilige stallen (effecten nu en in de toekomst)

3. Is door activiteiten binnen het Actieplan het inzicht in stalbranden en de oorzaken ervan toegenomen

4. Welke activiteiten zijn zinvol als voortzetting van het Actieplan en welke indicatie van kosten hoort daarbij (advies + kostenindicatie)

\section{Leeswijzer}

Hoofdstuk 2 beschrijft de aanpak van het onderzoek. Hoofdstuk 3 geeft een samenvatting van ingezette activiteiten binnen het Actieplan. Hoofdstuk 4 geeft een overzicht van stalbranden in de periode 2012-2016 en de (bekende) oorzaken ervan. In hoofdstuk 5 staat een samenvatting van de resultaten van de interviews met gemeenten/brandweer, bouwadviesbureaus en verzekeraars over ontwikkelingen in brandveiligheid. Hoofdstuk 6 geeft de resultaten van een internetenquête onder veehouders naar attitude en handelen ten aanzien van brandgevaarlijke werkzaamheden. In hoofdstuk 7 zijn ontwikkelingen binnen de sectoren geschetst die een relatie kunnen hebben met brandveiligheid. In hoofdstuk 8 worden de bevindingen bediscussieerd. In hoofdstuk 9 geven we conclusies over het effect van ingezette activiteiten binnen het Actieplan en mogelijke vervolgactiviteiten. In hoofdstuk 10 adviseren we over follow up en/of aanvulling van activiteiten binnen het Actieplan, inclusief een beknopte kostenindicatie. 


\section{Werkwijze}

\section{Inventarisatie van activiteiten binnen het Actieplan}

De werkgroep Actieplan Stalbranden heeft een overzicht aangeleverd bij het onderzoeksteam van de activiteiten die binnen de looptijd van het Actieplan zijn uitgevoerd of in gang gezet (bijlage 1). Deze activiteiten zijn deels beschreven in de tussentijdse voortgangsrapportages die zijn opgesteld door de werkgroep Actieplan. Aanvullend heeft de werkgroep Actieplan een tabel aangeleverd met activiteiten die in 2016 zijn uitgevoerd. De opsomming is door het onderzoeksteam niet geverifieerd op compleetheid of inhoud, maar als vaststaand gegeven beschouwd. Het te evalueren effect van het Actieplan (huidig en toekomstig effect) wordt gezien als een resultante van deze activiteiten.

De werkgroep Actieplan heeft tevens aangegeven welke concrete maatregelen zijn of op korte termijn worden opgenomen in de private kwaliteitssystemen Beter Leven en Maatlat Duurzame Veehouderij (MDV).

\section{Inzicht in stalbranden en hun oorzaken}

De werkgroep Actieplan Stalbranden heeft informatie over het aantal stalbranden in 2012 en 2013 (in voortgangsrapportages) en 2014, 2015 en 2016 (in een apart bestand) aangeleverd. Sinds 2014 registreert Brandweer Nederland in samenwerking met het Verbond van Verzekeraars iedere stalbrand. Voor de jaren 2012 en 2013 is dit uitgevoerd door alleen de verzekeraars. Volgens de werkgroep Actieplan Stalbranden zijn de cijfers voor 2014, 2015 en 2016 nauwkeuriger dan in voorgaande jaren. De gegevens over stalbranden en dierlijke slachtoffers in de periode 2012-2016 zijn gerelateerd aan de CBS-gegevens over aantallen bedrijven en dieren binnen de verschillende sectoren in 2014.

\section{Inschatting effect Actieplan (beoordelingskader)}

Inschatting van het effect van de ingezette acties op brandveiligheid voor dieren in veestallen kan op twee manieren: direct-kwantitatief of indirect-kwalitatief.

Een directe kwantitatieve effectmeting van de activiteiten van het actieplan op brandveiligheid voor dieren in veestallen is nog niet op zinvolle wijze uitvoerbaar. Een directe effectmeting zou zich baseren op het aantal stalbranden en het aantal dieren dat bij stalbranden is omgekomen na de start van het actieplan ten opzichte van een referentieperiode (bv. 2005-2009). Argument tegen directe effectmeting is de relatief korte looptijd waarin maatregelen die genomen zijn tot een effect hebben kunnen leiden. Dit geldt in het bijzonder voor maatregelen zoals wijzigingen in het Bouwbesluit (van kracht per 1-4-2014), die alleen bij nieuwbouw en ingrijpende renovatie (en daarmee gefaseerd) tot realisatie komen. Een enkel stalbrandincident kan het gemiddelde in een jaar sterk beïnvloeden. Stalbrandincidenten dienen volgens het onderzoeksteam om die reden over een periode van meerdere jaren te worden uitgemiddeld. In par. 9.2 geven we een inschatting van het tijdpad waarin ingezette activiteiten op verschillende onderdelen van brandveiligheid tot een effect kunnen komen.

Een indirecte kwalitatieve effectmeting is wel mogelijk. Daarbij richt de evaluatie van het effect van activiteiten binnen het Actieplan zich op een kwalitatieve inschatting van de risicoreductie door de ingezette activiteiten. Risico = kans $x$ 'effect'. Het 'effect' wordt in dit geval gedefinieerd als het aantal dieren dat door stalbrand omkomt (afgeleid uit doelstelling Actieplan Stalbranden). Bij een gegeven omvang van een dierverblijf-brandcompartiment zit er op beïnvloeding van het 'effect' binnen de intensieve veehouderij doorgaans geen of weinig handelingsperspectief: de dieren zijn in de regel niet te evacueren en moeten bij een (uitgebreide) stalbrand als verloren worden beschouwd. In de melkveehouderij ligt dit anders. Het 'effect' is wel beïnvloedbaar door beperkingen te stellen aan de omvang van brandcompartimenten waarin dieren verblijven.

De evaluatie van het effect van het Actieplan op risicoreductie richt zich vooral op inschatting van de mate waarin de overall kans op brand met dierlijke slachtoffers als gevolg van de ingezette activiteiten is beïnvloed, nu en naar de toekomst toe. Deze overall kans is op te splitsen in subthema's met 
deelkansen (fig. 2.1). Dit vormt gelijker tijd het beoordelingskader voor de evaluatie van het effect van ingezette activiteiten.

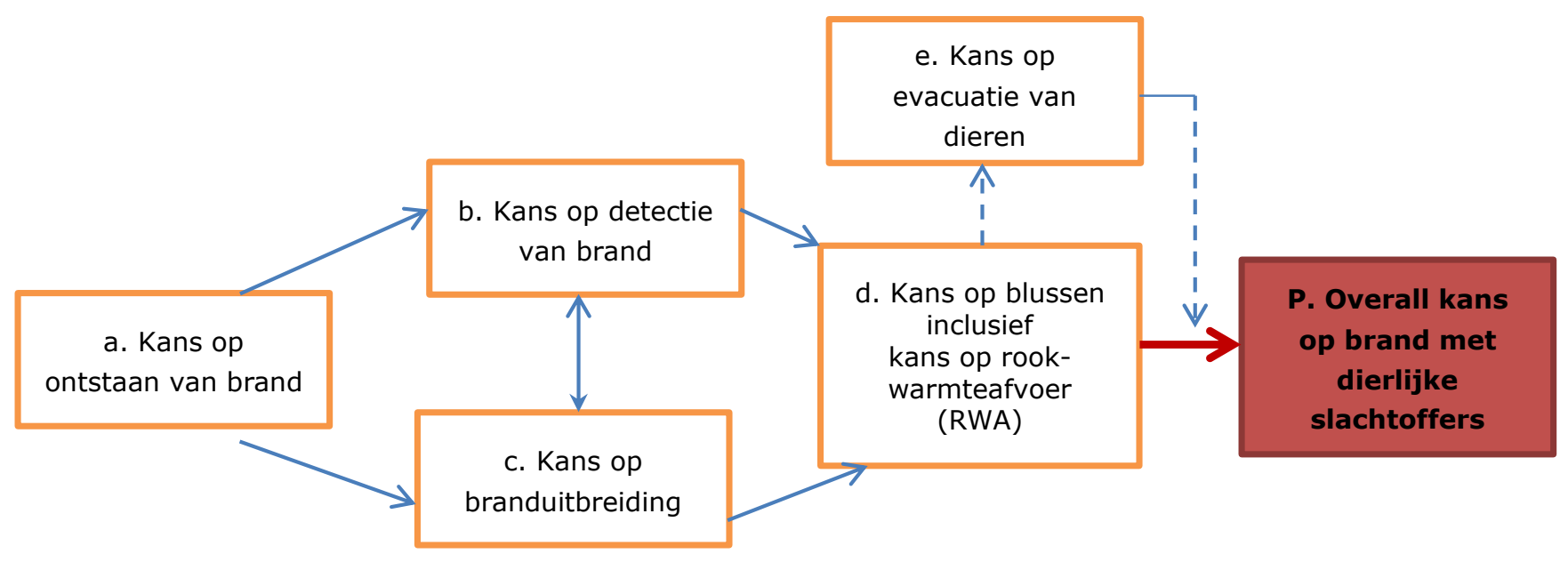

Figuur 2.1 Invloedsdiagram-beoordelingskader: opdeling overall kans op brand met dierlijke slachtoffers in deelkansen die met elkaar samenhangen (o.b.v. rapport Brandweeracademie, 2014 ${ }^{1}$ )

Conform het beoordelingskader in figuur 1 heeft het onderzoek naar inschatting van effect van ingezette activiteiten zich gericht op een kwalitatieve inschatting van:

a. Veranderingen in de kans op het ontstaan van brand, o.a. in relatie met:

i. Elektriciteit/kortsluiting (bedrading, apparatuur, ..)

ii. Werkzaamheden (lassen, slijpen, afvalverbranding, dakdekken, ..))

iii. Zelfontbranding/oververhitting (apparatuur, machines zoals trekkers, ..)

iv. Anders, nl..

b. Veranderingen in de kans op snelle detectie

i. Automatische detectiesystemen; detectie door personen; ..

c. Veranderingen in de kans op snelle branduitbreiding

i. Beperking snelheid brandvoortplanting door brandklasse van materialen in stal (hokinrichting/aankleding/isolatie; vlottende materialen zoals strooisel; ..)

ii. Beperking branduitbreiding via compartimentering;

d. Veranderingen in de kans op blussen van (lokale) brand

i. Automatische blussystemen; handmatige blusvoorzieningen; ..

Veranderingen in de toepassing van (automatische) rook-warmteafvoer (RWA)

i. RWA in combinatie met dagelijks ventilatiesysteem; of apart RWA-systeem; altijd i.c.m. temperatuurdetectiesysteem. Niet relevant voor melkvee.

e. Veranderingen in de kans op evacuatie van dieren bij stalbrand

Om deze effecten en de huidige situatie van brandveiligheid te kunnen inschatten zijn de onderstaande activiteiten uitgevoerd.

\section{Interviews met stakeholders}

Er zijn 3 gemeenten samen met hun brandweer, 3 bouwadviesbureaus en 2 verzekeraars geïnterviewd. De organisaties zijn door twee onderzoekers (van WUR en van IFV) geïnterviewd. Het gesprek is gevoerd aan de hand van een vragenlijst (bijlage 2). Deze vragenlijst is ter voorbereiding vooraf toegestuurd aan de te interviewen personen. Van elk interview is een verslag gemaakt waarin de antwoorden op de vragen zijn samengevat. Dit verslag was uitsluitend voor eigen gebruik door het onderzoeksteam.

In de interviews is geëvalueerd welke ontwikkelingen er in de afgelopen 4-5 jaren zijn geweest in de kans op brand in veestallen met dierlijke slachtoffers. Ontwikkelingen zijn ingeschat voor elk van de deelthema's in het beoordelingskader van fig. 2.1, voor respectievelijk nieuwbouw en voor bestaande stallen. Elk van de geïnterviewde organisaties was ook in 2012 binnen het WUR/IFV-onderzoek naar

\footnotetext{
${ }^{1}$ Brandweeracademie, 2014. Risicovergelijking brandveiligheid van stallen groter dan $2500 \mathrm{~m}^{2}$ met stallen tot $2500 \mathrm{~m}^{2}$. Brandweeracademie is onderdeel van Instituut Fysieke Veiligheid.
} 
brandveiligheid voor dieren in veestallen geïnterviewd (WLR-rapport 641). De conclusies uit 2012 kunnen daarom als een soort nulmeting worden beschouwd en zijn gebruikt als referentie bij de beschrijving van veranderingen in de periode 2012-2016. Bij elk van de deelthema's is tevens geïnventariseerd welke mogelijkheden men ziet om de brandveiligheid op de deelgebieden verder te verbeteren. Ook is gevraagd naar de mening over de rol die het Actieplan heeft gespeeld in de waargenomen veranderingen.

\section{Internetenquête onder veehouders}

Veranderingen in houding ten aanzien van brandveiligheid van veestallen en brandveilig handelen zijn deels via de eerdergenoemde interviews inzichtelijk gemaakt. Aanvullend is, verspreid via de kanalen van LTO, een beknopte internetenquête uitgezet onder veehouders, waarin vragen over brandveilig handelen zijn opgenomen. De enquête is door 217 veehouders ingevuld, waarvan 24 pluimveehouders, 63 varkenshouders, 122 melkveehouders en 8 vleeskalverhouders. Hiervan hebben 202 veehouders alle vragen beantwoord. De vragen van de internetenquête zijn in bijlage 3 weergegeven.

\section{Toekomstige ontwikkelingen}

Er is een inschatting gemaakt van de (snelheid van implementatie van) ontwikkelingen in de brandveiligheid van stallen als gevolg van maatregelen die in gang zijn gezet via wijzigingen van het Bouwbesluit en stimuleringsmaatregelen zoals de brandveiligheidsmodule binnen de Maatlat Duurzame Veehouderij. Via expertkennis is een inschatting gemaakt van de mogelijke invloed van autonome en marktontwikkelingen in de verschillende sectoren op de toekomstige brandveiligheid van dieren in veestallen. Aspecten zoals schaalvergroting, technische innovaties en marktconcepten op gebied van dierenwelzijn zijn hierbij belicht.

Er is opgevraagd hoeveel stallen in de periode 2014-2016 met MDV (Maatlat Duurzame Veehouderij)certificaat zijn gebouwd en hoeveel punten zijn behaald op de MDV-module brandveiligheid (aantal bedrijven met minimaal verplicht aantal punten en aantal bedrijven met substantieel meer punten voor module brandveiligheid). Er is een inschatting gemaakt van het investeringsritme in stalbouw, inrichting en technische installaties in de verschillende veehouderijsectoren, mede op basis van geldende afschrijvingstermijnen.

\section{Discussie en conclusies}

De resultaten van de voorgaande stappen zijn door het onderzoeksteam geanalyseerd. Daarbij zijn conclusies getrokken over de belangrijkste ontwikkelingen in brandveiligheid van stallen in de periode 2012-2016, actuele aandachtspunten en mogelijke oplossingsrichtingen. Er is een beoordeling gemaakt van het huidige inzicht in stalbranden en hun oorzaken, alsmede verbetermogelijkheden daarbij. Conclusies zijn gestructureerd aan de hand van de sporen van het actieplan.

\section{Advies voortzetting activiteiten + kostenindicatie}

Op basis van de bevindingen en rekening houdend met vervangingsritmes van stallen, stalinrichting en technische installaties is, met de belangrijkste focus op bestaande stallen, aangegeven welke voortzetting van activiteiten of aanvullingen daarop kunnen helpen om de brandveiligheid voor dieren in veestallen verder te verhogen. In het advies is bij mogelijke aanvullende maatregelen op stalniveau een kostenindicatie gegeven. 


\section{Activiteiten Actieplan samengevat}

De activiteiten binnen Actieplan Stalbranden 2012-2016 en de stand van zaken ervan zijn door de werkgroep Actieplan beschreven in de voortgangsrapportage van 2016 (bijlage 1), en in de onderstaande tabel samengevat. De opsomming en aangegeven stand van zaken is door het onderzoeksteam niet geverifieerd op compleetheid of inhoud, maar als vaststaand gegeven beschouwd. Het te evalueren effect van het actieplan wordt gezien als een resultante van deze activiteiten.

Tabel 3.1 Samenvatting van de activiteiten binnen Actieplan stalbranden 2012-2016 en aangegeven stand van zaken (bron: initiatiefnemers Actieplan Stalbranden)

A. Brandveilige bedrijfsvoering

\begin{tabular}{l} 
Voorgenomen activiteit \\
Opschalen praktijknetwerken \\
Doel: praktische oplossingen vinden voor vergroten \\
brandveiligheid nieuwe en bestaande stallen \\
5-10 Themabijeenkomsten per jaar \\
Doel: bewustzijn brandveiligheid veehouders en \\
erfbetreders vergroten \\
\hline 3-5 Nieuwsbrieven per jaar \\
Doel: bewustzijn veehouders over brandveiligheid \\
vergroten en handelingsperspectieven bieden \\
Ontwikkeling onderwijsmodule brandveiligheid \\
Doel: brandveiligheid opgenomen krijgen in reguliere \\
onderwijsmodules van agrarisch onderwijs
\end{tabular}

B. Brandveilige stallen voor mens en dier Voorgenomen activiteit

Verbetering samenwerking dierenarts-brandweer Doel: zorgen voor snelle diergeneeskundige hulp bij brand in geval van vaste dierenarts op afstand Kennisniveau bij stallenbouwer, gemeente en veehouder over wet- en regelgeving vergroten Doel: Kennisniveaus vergroten

Onderzoek Europees recht naar mogelijkheid om open verwarmingssystemen te verbieden Doel: Risico gebruik open-vuur heaters verminderen Gelijkwaardigheid van brandveiligheid bij grotere brandcompartiment $>2.500 \mathrm{~m}^{2}$ Doel: Handvatten voor beoordeling gelijkwaardigheid

\section{Stand van zaken}

Praktijknetwerk varkens is opgeschaald naar rundvee en pluimvee. Begeleiding door DLV.

50 bijeenkomsten gehouden ( 20 algemeen, 17 rundveesector, 4 varkenssector, 4 pluimveesector, 1 konijnensector, 2 paardensector, 2 specifieke bijeenkomsten voor erfbetreders). Betrokkenheid verschillende partijen bij lezingen (LTO, brandweer, verzekeraars, STIGAS)

Via reguliere informatiekanalen voor veehouders en erfbetreders in groot aantal artikelen gecommuniceerd over Actieplan, aanpassingen Bouwbesluit, risico's, tips en tools. Folders en cartoonachtige tekeningen zijn ontwikkeld.

Dit lukt nog niet goed, onderwijsprogramma's zitten vol.
C. Stimuleren van brandveilige stallen

\section{Voorgenomen activiteit}

Aparte categorie brandveiligheid in Maatlat Duurzame

Veehouderij

Doel: Via fiscale voordelen investering in

bovenwettelijke maatregelen op gebied van brandveiligheid stimuleren

Periodieke elektrakeuringen regelen via kwaliteitssystemen Doel: Risico van kortsluiting/zelfontbranding door elektra verminderen

Brandveiligheid onderdeel maken van integrale

handhavingsstrategie

Doel: Handhaven op brandveiligheid

Stimuleren van innovatie van detectiesystemen Doel: Praktijkrijpe detectiesystemen in stal krijgen

Eenduidiger beleid bij gemeenten Doel: Verschillen in beoordeling gelijkwaardigheid grote brandcompartimenten wegnemen

Aanpassen en implementeren regelgeving Doel: Brandveiligheid veestallen versterken

\section{Stand van zaken}

Handreiking van KNMvD/brandweer voor snel dierenarts ter plaatse en wat partijen van elkaar verwachten in geval van bv. euthanasie is nagenoeg afgerond

Communicatie over regelgeving via LTO-

ledenbijeenkomsten, artikelen in vakbladen en via helpdesk ministerie BZK.

Verbod is in strijd met EU-regelgeving. Gekozen voor voorlichting over risico's aan veehouders via vakbladen. Wordt nog gerealiseerd.

Rapport IFV 'Risicovergelijking van stallen $>2.500 \mathrm{~m}^{2}$. Grotere brandcompartimenten mogelijk bij toepassen gelijkwaardigheid NEN voor veestallen (in ontwikkeling).

\section{Stand van zaken}

Gerealiseerd sinds 1-1-2014. MDV-certificaat wordt tevens beloond in Brabantse Zorgvuldigheidsscore Veehouderij, en daarmee keuzemaatregelen brandveiligheid.

Periodieke keuring opgenomen in Beter Leven-keurmerk Dierenbescherming. Opname in IKB's staat nog als actiepunt.

Niet mogelijk. Omgevingsdiensten gevraagd om bij handhaven ook te letten op brandveiligheid. Hiervoor wordt leaflet ontwikkeld.

Werkgroep Actieplan is aanspreekpunt voor bedrijven met innovaties.

Al minder verschillen in beleid door vorming brandweer Nederland en 25 veiligheidsregio's. Bij realisatie landelijke NEN-norm is probleem opgelost.

Aanpassing Bouwbesluit per 1-4-2014 met dierverblijven als aparte subcategorie, technische ruimte $60 \mathrm{~min}$ brandwerend en isolatie-/aankledingsmateriaal minimaal brandklasse B. Via IFV naleving in bouwpraktijk onderzocht. 
D. Verbeterd inzicht in oorzaken van stalbranden en betere beheersbaarheid

\begin{tabular}{|c|c|}
\hline Voorgenomen activiteit & Stand van zaken \\
\hline $\begin{array}{l}\text { Betere registratie van stalbranden } \\
\text { Doel: Beter inzicht in incidentie van stalbranden per } \\
\text { sector }\end{array}$ & $\begin{array}{l}\text { Brandweer Nederland registreert sinds } 2014 \text { iedere } \\
\text { stalbrand. }\end{array}$ \\
\hline $\begin{array}{l}\text { Onderzoek naar oorzaken van stalbranden } \\
\text { Doel: Meer kennis over oorzaken van stalbranden }\end{array}$ & $\begin{array}{l}\text { Vanaf } 2014 \text { wordt bij alle stalbranden de oorzaak van de } \\
\text { brand onderzocht. In } 2014 / 2015 \text { zelfde beeld van } \\
\text { brandoorzaken als bij begin actieplan. }\end{array}$ \\
\hline
\end{tabular}

Tevens is binnen het kader van het Actieplan een literatuurstudie uitgevoerd naar de mogelijkheden om niet te redden dieren zo snel mogelijk te euthanaseren (Kluivers en Hindle, 2015).

In hoofdstuk 9 worden conclusies getrokken over het effect van ingezette activiteiten en zinvolle vervolgactiviteiten.

Het volgende hoofdstuk beschrijft het aantal stalbranden en dierlijke slachtoffers in de looptijd van het Actieplan en de oorzaken ervan. 


\section{$4 \quad$ Stalbranden en oorzaken}

\subsection{Aantal stalbranden en dierlijke slachtoffers 2012-2016}

Tabel 4.1 geeft een overzicht van de stalbranden die hebben plaatsgevonden in de periode 2012-2016 en het aantal dieren dat hierbij is omgekomen. Het overzicht heeft betrekking op varkens, pluimvee, kalveren en overig rundvee (m.n. melkvee). Sinds 2014 registreert Brandweer Nederland in samenwerking met het Verbond van Verzekeraars iedere stalbrand, als activiteit voortvloeiend uit het Actieplan. De informatie over de jaren 2014-2016 is afkomstig uit deze registratie. De informatie over de jaren 2012 en 2013 is afkomstig van verzekeraars. Volgens de werkgroep Actieplan Stalbranden zijn de cijfers voor 2014, 2015 en 2016 nauwkeuriger dan in voorgaande jaren.

Tabel 4.1 Overzicht van totaal aantal stalbranden per sector in 2012-2016 en aantal dierlijke slachtoffers

\begin{tabular}{|c|c|c|c|c|c|c|}
\hline & & \multicolumn{2}{|c|}{ Rundveehouderij } & \multirow[t]{2}{*}{ Varkenshouderij } & \multirow[t]{2}{*}{ Pluimveehouderij } & \multirow[t]{2}{*}{ Totaal } \\
\hline & & Kalveren & $\begin{array}{l}\text { Overig } \\
\text { rundvee }\end{array}$ & & & \\
\hline \multirow[t]{2}{*}{2012} & Aantal stallen & 1 & 4 & 6 & 4 & 15 \\
\hline & Aantal dieren & 3 & 1 & 4.600 & 86.030 & 90.634 \\
\hline \multirow[t]{2}{*}{2013} & Aantal stallen & 4 & 5 & 9 & 5 & 23 \\
\hline & Aantal dieren & 515 & 4 & 7.781 & 17.000 & 25.300 \\
\hline \multirow[t]{2}{*}{2014} & Aantal stallen & 3 & 14 & 6 & 5 & 28 \\
\hline & Aantal dieren & 0 & 33 & 5.770 & 32.000 & 37.803 \\
\hline \multirow{2}{*}{2015} & Aantal stallen & 7 & 11 & 5 & 3 & 26 \\
\hline & Aantal dieren & 86 & 9 & 4.105 & 129.000 & 133.200 \\
\hline \multirow[t]{2}{*}{2016} & Aantal stallen & 10 & 9 & 8 & 8 & 35 \\
\hline & Aantal dieren & 418 & 41 & 13.592 & 185.000 & 199.051 \\
\hline \multirow{2}{*}{$\begin{array}{l}\text { Totaal } \\
2012- \\
2016\end{array}$} & $\begin{array}{l}\text { Aantal } \\
\text { stallen }\end{array}$ & 25 & 43 & 34 & 25 & 127 \\
\hline & $\begin{array}{l}\text { Aantal } \\
\text { dieren }\end{array}$ & 1022 & 88 & 35.848 & 449.030 & 485.988 \\
\hline
\end{tabular}

In tabel 4.2 zijn de beschikbare cijfers over het aantal stalbranden in de periode 2012-2016 en het aantal dieren dat daarbij is omgekomen afgezet tegen dezelfde kengetallen in de referentieperiode 2005-2009 (bron: WUR/IFV-rapport 2012). In het tweede deel van de tabel zijn ook de totale aantallen bedrijven en aantallen dieren in 2007 (als gemiddelde voor de periode 2005-2009) en 2014 (als gemiddelde voor de periode 2012-2106) weergegeven. Het hieruit afgeleide gemiddeld aantal dieren per bedrijf per sector geeft een indicatie van de omvang van de schaalvergroting in de loop der jaren.

Tabel 4.2 Aantal stalbranden en omgekomen dieren in de periode 2005-2009 (Bron: Rapport Brand in veestallen) en periode 2012-2016 (bron: Brandweer Nederland en CBS Landbouwtelling)

\begin{tabular}{|c|c|c|c|c|c|c|}
\hline & \multicolumn{2}{|c|}{ Rundveehouderij } & \multicolumn{2}{|c|}{ Varkenshouderij } & \multicolumn{2}{|c|}{ Pluimveehouderij } \\
\hline & $\begin{array}{r}\text { '05-'09 } \\
(\text { gem/jaar) }\end{array}$ & $\begin{array}{r}' 12-' 16 \\
(\mathrm{gem} / \mathrm{jaar})\end{array}$ & $\begin{array}{r}\text { '05-'09 } \\
\text { (gem/jaar) }\end{array}$ & $\begin{array}{r}' 12-' 16 \\
(\text { gem/jaar) }\end{array}$ & $\begin{array}{r}\text { '05-'09 } \\
\text { (gem/jaar) }\end{array}$ & $\begin{array}{r}\text { '12-'16 } \\
\text { (gem/jaar) }\end{array}$ \\
\hline $\begin{array}{l}\text { Totaal aantal } \\
\text { stalbranden }\end{array}$ & $410(82)$ & $68(14)$ & $242(48)$ & $34(7)$ & $111(22)$ & $25(5)$ \\
\hline $\begin{array}{l}\text { Aantal stalbranden } \\
\text { waarbij dieren } \\
\text { omkwamen }\end{array}$ & $57(11)$ & $\begin{array}{r}(' 14-' 16) \\
19(6)\end{array}$ & $64(13)$ & $\begin{array}{r}(\mathbf{1 4 -}-16) \\
13(4)\end{array}$ & $30(6)$ & $\begin{array}{r}\left(\mathbf{1}^{14-16)}\right. \\
12(4)\end{array}$ \\
\hline $\begin{array}{l}\text { Totaal aantal } \\
\text { omgekomen dieren }\end{array}$ & $1.422(284)$ & $1.110(222)$ & $\begin{array}{l}23.724 \\
(4.745)\end{array}$ & $\begin{array}{l}35.848 \\
(7.168)\end{array}$ & $\begin{array}{r}711.934 \\
(142.387)\end{array}$ & $\begin{array}{l}449.030 \\
(89.806)\end{array}$ \\
\hline $\begin{array}{l}\text { Gemiddeld aantal } \\
\text { omgekomen dieren } \\
\text { per bedrijf }\end{array}$ & 25 & $\begin{array}{r}(' 14-16) \\
31\end{array}$ & 365 & $\begin{array}{r}(\mathbf{1 4 -} \mathbf{1 6}) \\
1.805\end{array}$ & 23.731 & $\begin{array}{r}\text { ('14-'16) } \\
28.833\end{array}$ \\
\hline & 2007: & 2014: & 2007: & 2014: & 2007: & 2014: \\
\hline $\begin{array}{l}\text { Aantal bedrijven in } \\
\text { referentiejaar }\end{array}$ & 35.258 & 29.670 & 8.692 & 5.110 & 2.662 & 2.180 \\
\hline $\begin{array}{l}\text { Aantal dieren in } \\
\text { referentiejaar }\end{array}$ & 3.763 .000 & 4.068 .330 & 11.663 .000 & 12.238 .120 & 92.763 .000 & $\begin{array}{r}104.737 .80 \\
0\end{array}$ \\
\hline $\begin{array}{l}\text { Gemiddeld aantal } \\
\text { dieren per bedrijf in } \\
\text { referentiejaar }\end{array}$ & 107 & 137 & 1.342 & 2.395 & 34.847 & 48.045 \\
\hline
\end{tabular}


De kans op het ontstaan van brand op een veebedrijf is relatief gezien klein. Uit tabel 4.2 leiden we de volgende kansen op het ontstaan van brand voor de verschillende type veebedrijven af [Let op: de periode 2005-2009 betreft alle gevallen met brandschade die bij de verzekering zijn gemeld; de periode 2012-2016 betreft stalbranden waar de brandweer bij is geweest]:

$\begin{array}{lll} & \underline{2005-2009} & \underline{2012-2016} \\ \text { - } \begin{array}{l}\text { bundveebedrijf: } \\ \text { bedrijven) }\end{array} & \mathrm{p}=0.002(=2 \text { op de } 1000 \text { bedr. }) & \mathrm{p}=0.0005(=5 \text { per } 10.000 \\ \text { - } \begin{array}{l}\text { varkensbedrijf: } \\ \text { pluimveebedrijf: }\end{array} \quad \mathrm{p}=0.006 & \mathrm{p}=0.008 & \mathrm{p}=0.0014 \\ & & 0.0023\end{array}$

Ter vergelijk: in Nederland komt er per 1000 woningen gemiddeld 1 brand per jaar voor. De kans op brand op een veebedrijf waar de brandweer aan te pas komt, ligt in de periode 2012-2106 op rundveebedrijven een factor 2 (rundvee) lager, op varkensbedrijven een factor 1,4 hoger en op pluimveebedrijven een factor 2,3 hoger dan bij woningbranden.

De kans dat er dieren op een bedrijf omkomen door stalbrand is (nog) kleiner:

\begin{tabular}{|c|c|c|}
\hline & $2005-2009$ & 2012-2016 \\
\hline - rundve & $p=0.0003$ (= 3 op de 10.000 bedrijven $)$ & $p=0.0002$ \\
\hline var & $p=0.0015$ & $p=0.0008$ \\
\hline pluimve & $p=0.0023$ & $p=0.0018$ \\
\hline
\end{tabular}

De kans op het ontstaan van stalbrand is relatief gezien gering; het effect, de impact van een stalbrand is doorgaans aanzienlijk, afgemeten aan de absolute aantallen dieren die omkomen. [Andere impacts dan dierveiligheid, zoals in financieel (incl. bedrijfscontinuïteit) en/of psychologisch opzicht, buiten beschouwing gelaten] Gemiddeld kwamen in de periode 2012-2016 per jaar circa 220 runderen, 7.170 varkens en 90.000 kippen om bij stalbranden. [Dit betreft respectievelijk $0.006 \%$ van het totale aantal runderen, $0.059 \%$ van het totale aantal varkens en $0.086 \%$ van het totale aantal stuks pluimvee in referentiejaar 2014.] Het gemiddeld aantal runderen en kippen dat jaarlijks is omgekomen is daarmee lager, het gemiddeld aantal omgekomen varkens per jaar is (beduidend) hoger dan in de periode 2005-2009.

De cijfers dienen met voorzichtigheid te worden geïnterpreteerd. Door de systematische registratie van stalbrandincidenten sinds 2014 door Brandweer Nederland in samenwerking met het Verbond van Verzekeraars geven de cijfers over de periode 2014-2016 naar verwachting een betrouwbaarder beeld van de werkelijkheid dan de cijfers over de periode 2005-2009 en 2012-2013, die alleen door verzekeraars zijn aangedragen. Hier zitten bijvoorbeeld ook schademeldingen bij voor branden waar geen brandweer bij betrokken is geweest. Harde uitspraken over verschillen in aantallen incidenten tussen beide 5 -jaars perioden kunnen om die reden niet worden gedaan.

\subsection{Oorzaken van stalbranden}

Sinds 2014 doet Brandweer Nederland in samenwerking met het Verbond van Verzekeraars systematisch onderzoek naar de oorzaken van stalbranden en registreert de (vermoedelijke) oorzaak bij ieder incident. Niet altijd kan een oorzaak worden achterhaald. Dat heeft in sommige gevallen te maken met het vrijkomen van asbest, waardoor het terrein van het incident niet altijd (direct) toegankelijk is voor nader onderzoek.

In tabel 4.3 zijn de meest voorkomende oorzaken van stalbranden bij de verschillende sectoren in 2005-2009 en 2014-2016 samengevat. Alle incidenten in 2014, 2015 en 2016 betreft veestallen die dateren van vóór 1-4-2014, het moment waarop nieuwe brandveiligheidsvoorschriften voor nieuw te vergunnen stallen in Bouwbesluit 2012 zijn opgenomen.

Uit de registratie van oorzaken blijkt dat elektriciteit/kortsluiting nog steeds de belangrijkste oorzaak van stalbrand is in de periode 2014-2016, met werkzaamheden eveneens nog steeds op de tweede plaats. Wat opvalt, is dat blikseminslag op de derde plaats staat. In de jaren 2014 en 2015 verschijnt blikseminslag ineens als relatief frequente veroorzaker van stalbrand. Van ruim $55 \%$ van de 
stalbranden in 2014, 2015 en 2016 is de oorzaak onbekend. In de periode 2005-2009 werd bij circa $30 \%$ van de stalbranden de oorzaak onbekend gegeven.

Tabel 4.3 Meest voorkomende brandoorzaken bij pluimvee, varkens en rundvee in 2005-2009 en 2014-2016

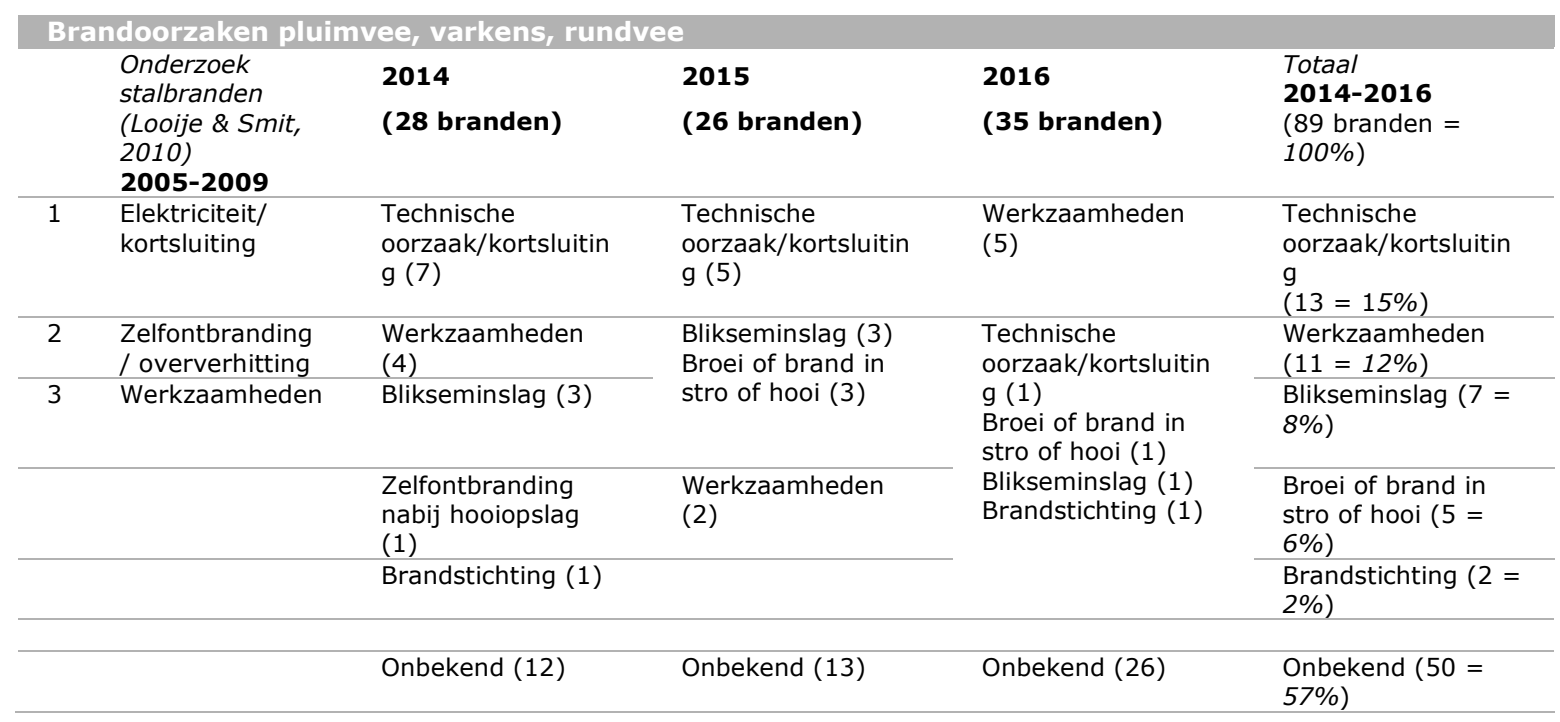

In de tabellen $4.4 \mathrm{t} / \mathrm{m} 4.7$ zijn de oorzaken van stalbranden per veehouderijsector weergegeven.

Tabel 4.4 Oorzaken van stalbranden bij pluimvee in 2014, 2015 en 2016 (bron: Cijfers Actieplan Stalbranden)

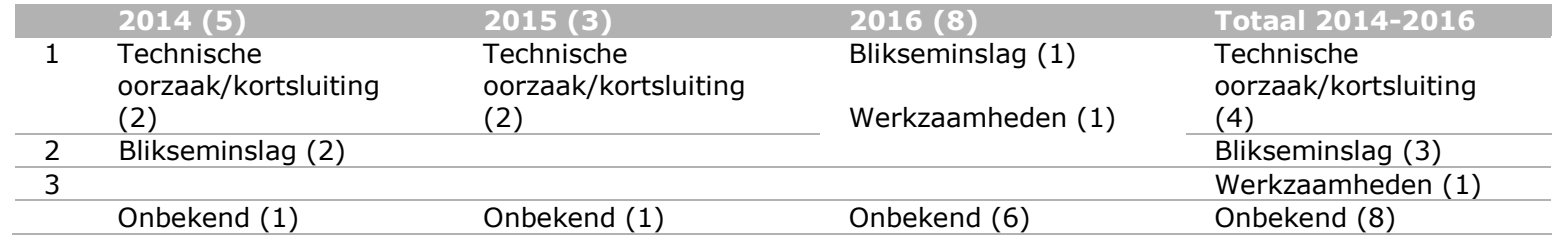

Tabel 4.5 Oorzaken van stalbranden bij varkens in 2014, 2015 en 2016 (bron: Cijfers Actieplan Stalbranden)

\begin{tabular}{|c|c|c|c|c|}
\hline & $2014(6)$ & $2015(5)$ & $2016(8)$ & Totaal 2014-2016 \\
\hline 1 & $\begin{array}{l}\text { Technische } \\
\text { oorzaak/kortsluiting } \\
\text { (3) }\end{array}$ & $\begin{array}{l}\text { Technische } \\
\text { oorzaak/kortsluiting } \\
\text { (1) }\end{array}$ & Werkzaamheden (2) & $\begin{array}{l}\text { Technische } \\
\text { oorzaak/kortsluiting } \\
\text { (4) }\end{array}$ \\
\hline 2 & & Blikseminslag (1) & Brandstichting (1) & Werkzaamheden (2) \\
\hline 3 & & & & $\begin{array}{l}\text { Blikseminslag (1) } \\
\text { Brandstichting (1) }\end{array}$ \\
\hline
\end{tabular}

Tabel 4.6 Oorzaken van stalbranden bij kalveren in 2014, 2015 en 2016 (bron: Cijfers Actieplan Stalbranden)

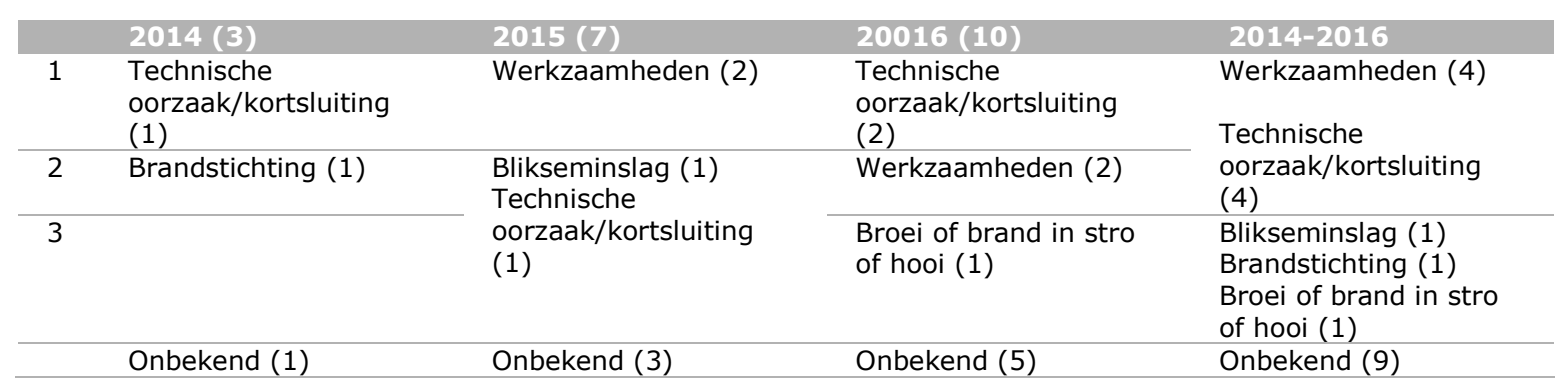


Tabel 4.7 Oorzaken van stalbranden bij overig rundvee in 2014, 2015 en 2016 (bron: Cijfers Actieplan Stalbranden)

\begin{tabular}{|c|c|c|c|c|}
\hline & $2014(14)$ & $2015(11)$ & $2016(9)$ & 2014-2016 \\
\hline 1 & Werkzaamheden (4) & $\begin{array}{l}\text { Broei of brand in stro } \\
\text { of hooi (3) }\end{array}$ & Werkzaamheden (3) & Werkzaamheden (7) \\
\hline 2 & \multirow{4}{*}{$\begin{array}{l}\text { Technische } \\
\text { oorzaak/kortsluiting } \\
\text { (1) } \\
\text { Blikseminslag (1) } \\
\text { Zelfontbranding nabij } \\
\text { hooiopslag (1) }\end{array}$} & \multirow{4}{*}{$\begin{array}{l}\text { Blikseminslag (1) } \\
\text { Technische } \\
\text { oorzaak/kortsluiting } \\
\text { (1) }\end{array}$} & $\begin{array}{l}\text { Broei of brand in stro } \\
\text { of hooi ( } 3 \text { ) }\end{array}$ & $\begin{array}{l}\text { Broei of brand in stro } \\
\text { of hooi ( } 6)\end{array}$ \\
\hline 3 & & & $\begin{array}{l}\text { Technische } \\
\text { oorzaak/kortsluiting } \\
\text { (2) }\end{array}$ & $\begin{array}{l}\text { Technische } \\
\text { oorzaak/kortsluiting } \\
\text { (4) }\end{array}$ \\
\hline & & & & Blikseminslag (2) \\
\hline & & & & Zelfontbranding (1) \\
\hline & Onbekend (7) & Onbekend (6) & Onbekend (1) & Onbekend (14) \\
\hline
\end{tabular}

Hieruit komt het volgende naar voren:

- Belangrijkste oorzaken bij de intensieve sectoren: in de periode 2014-2016 komen elektriciteit/kortsluiting, met bij kalveren aanvullend ook werkzaamheden, het meest frequent voor als veroorzakers van stalbranden.

- Belangrijkste oorzaken bij overig rundvee (m.n. melkveehouderij): in de periode 2014-2016 komen hooi/strobrand (al dan niet in combinatie met zelfontbranding van werktuigen) en werkzaamheden het meest frequent voor als veroorzakers van stalbrand, gevolgd door elektriciteit/kortsluiting.

\section{Relatie oorzaken van stalbrand en dierlijke slachtoffers}

Tabel 4.8 geeft een overzicht van de relatie tussen het aantal dierlijke slachtoffers van een bepaalde diersoort en de oorzaak van de brand

Tabel 4.8 Aantal omgekomen dieren per oorzaak van brand

\begin{tabular}{|c|c|c|c|}
\hline \multicolumn{4}{|c|}{ Aantal dierlijke slachtoffers } \\
\hline Oorzaken & 2014 ( 27 branden) & 2015 ( 26 branden) & 2016 (35 branden) \\
\hline Onbekend & $\begin{array}{l}\mathbf{1 6 . 2 2 3} \\
3.800 \text { varkens } \\
23 \text { runderen } \\
15.000 \text { pluimvee }\end{array}$ & $\begin{array}{l}\mathbf{6 2 . 1 6 3} \\
2.105 \text { varkens } \\
7 \text { runderen } \\
51 \text { kalveren } \\
60.000 \text { pluimvee }\end{array}$ & $\begin{array}{l}\mathbf{8 6 . 8 5 2} \\
34 \text { runderen } \\
298 \text { kalveren } \\
1.520 \text { varkens } \\
85.000 \text { pluimvee }\end{array}$ \\
\hline Technisch & $\begin{array}{l}\mathbf{1 2 . 9 7 0} \\
1.970 \text { varkens } \\
11.000 \text { pluimvee }\end{array}$ & $\begin{array}{l}\mathbf{6 9 . 0 3 6} \\
69.000 \text { pluimvee } \\
35 \text { kalveren } \\
1 \text { rund }\end{array}$ & $\begin{array}{l}\mathbf{6 0 . 0 4 5} \\
7 \text { runderen } \\
108 \text { kalveren } \\
60.000 \text { pluimvee }\end{array}$ \\
\hline Broei/zelfontbranding & $\begin{array}{l}10 \\
10 \text { runderen }\end{array}$ & - & $\begin{array}{l}\mathbf{1 2} \\
12 \text { kalveren }\end{array}$ \\
\hline $\begin{array}{l}\text { Menselijk handen/ } \\
\text { werkzaamheden }\end{array}$ & - & - & $\begin{array}{l}\mathbf{1 2 . 0 7 2} \\
12.072 \text { varkens }\end{array}$ \\
\hline Bliksem & $\begin{array}{l}\mathbf{6 . 0 0 0} \\
6.000 \text { pluimvee }\end{array}$ & $\begin{array}{l}\mathbf{2 . 0 0 1} \\
1 \text { rund } \\
2.000 \text { biggen }\end{array}$ & $\begin{array}{l}\mathbf{4 0 . 0 0 0} \\
40.000 \text { pluimvee }\end{array}$ \\
\hline Totaal & 37.803 & 133.200 & 199.051 \\
\hline
\end{tabular}

Brandoorzaken blijken lastig te achterhalen (groot aandeel onbekend). Brand door broei of zelfontbranding heeft in 2014 t/m 2016 alleen dierlijke slachtoffers gemaakt in de rundveehouderij. Het aantal omgekomen dieren daarbij is gering. Mogelijk door een goede ruimtelijke scheiding tussen hooiopslag en dierverblijven, of omdat tijdige evacuatie mogelijk was. Van de bekende oorzaken van stalbranden maken branden met een technische oorzaak (kortsluiting, oververhitting) de meeste dierlijke slachtoffers. Maar ook bij brand door blikseminslag zijn in de periode 2014-2016 veel dieren omgekomen.

Het volgende hoofdstuk geeft een samenvatting van de resultaten van de interviews met gemeenten en brandweer, bouwadviesbureaus en verzekeraars. 


\section{$5 \quad$ Resultaten interviews}

In de interviews met gemeenten/brandweer, bouwadviesbureaus en verzekeraars is gevraagd welke ontwikkelingen/veranderingen er volgens hen in de afgelopen 4-5 jaren zijn geweest in de kans op brand in veestallen met dierlijke slachtoffers. De verschillende deelthema's in het beoordelingskader van fig. 1 hebben hierbij als leidraad gediend. Het gaat om het verkrijgen van een beeld van veranderingen in de kans op het ontstaan van brand (5.1), op snelle detectie (5.2), branduitbreiding (5.3), blussen (5.4), evacuatie en/of snelle euthanasie (5.5). De veranderingen die men ziet met betrekking tot grote brandcompartimenten zijn in 5.6 beschreven. Bij elk van de deelthema's is ook geïnventariseerd welke mogelijkheden men ziet om de brandveiligheid op het betreffende deelthema verder te verbeteren. In 5.7 is samengevat welke veranderingen de geïnterviewden zien in houding ten opzichte van brandveiligheid. Paragraaf 5.8 geeft een samenvatting van de visies van de geïnterviewden op toekomstige ontwikkelingen binnen de veehouderijsectoren in relatie met brandveiligheid. Tot slot is gevraagd welke rol men vindt dat het Actieplan heeft gespeeld in de waargenomen veranderingen (5.9). De bevraagde partijen zijn ook in 2012 in het onderzoek naar brandveiligheid voor dieren in veestallen (WUR/IFV) geïnterviewd. De conclusies uit 2012 dienden als referentie bij de beschrijving van de ontwikkelingen in de periode 2012-2016.

Dit hoofdstuk geeft een weergave van meningen van geïnterviewden over ontwikkelingen in brandveiligheid en verbetermogelijkheden.

\section{$5.1 \quad$ Over het ontstaan van brand}

Referentie [WUR/IFV-rapport 2012] Conclusies in 2012:

De belangrijkste veroorzakers van stalbrand waren:

* Elektriciteit;

- Kortsluiting in het elektrische circuit (mogelijk de nummer 1 oorzaak van stalbrand); Dit betreft het zelf installeren van 'onveilige' apparatuur of uitbreidingen met als gevolg overbelasting/oververhitting van kabels en groepen en dergelijke. Ook bij nieuwbouw blijkt er in $25 \%$ van de gevallen een of meerdere fouten in de aanleg van elektriciteit en installaties te zitten.

- Zelfontbranding/oververhitting van installaties (zoals mestverwerkers) en machines (zoals zelfontbranding van tractors in de stal).

* Verwarming met open systemen (m.n. gasheaters/heteluchtkanonnen bij vleeskuikens);

* Brandgevaarlijke werkzaamheden;

- Lassen, slijpen en dergelijke, al dan niet in combinatie met 'open' mestopslag (diepe mestputten) onder de roostervloeren in de dierverblijven of aanwezigheid van snel ontbrandbare materialen (bv hooi, stro) in de nabijheid.

Door geïnterviewden genoemde ontwikkelingen in de afgelopen jaren:

* De grote verzekeraars en sommige gemeenten eisen bij oplevering van een nieuwe stal een opleverings-elektrakeuring ((AgroElektrakeuring of NEN1010). Installatiefouten bij oplevering moeten worden hersteld voordat de stal in gebruik wordt genomen.

* Voor bestaande stallen is er vanuit de grote verzekeraars een ontwikkeling in gang gezet om een periodieke elektrakeuring als voorwaarde in de polis op te nemen (AgroElektrakeuring of NEN3140). Een verzekeraar heeft bij alle aangesloten varkens- en pluimveehouderijen in de afgelopen jaren een initiële elektrakeuring laten uitvoeren; melkveebedrijven komen de komende jaren aan de beurt. Deze verzekeraar wil periodieke elektrakeuring graag overhevelen naar de sectoren (private kwaliteitssystemen). Een andere verzekeraar laat periodiek een elektrakeuring conform NEN3140 uitvoeren bij haar grootschalige veehouderijen, met een frequentie afhankelijk van de betreffende sector.

* Compartimentering van de technische ruimte met een bepaalde brandwerendheid via het nieuwe Bouwbesluit wordt door de geïnterviewden gezien als een goede ontwikkeling. Men benadrukt wel dat niet alle risico's ermee uit de stal worden gehaald: de apparatuur voor dagelijkse bedrijfsprocessen, zoals motoren voor mest- en eiertransportbanden, melkrobots en ventilatoren, zitten nog steeds verspreid door de stal, is niet apart te compartimenteren.

* Onderhoud van apparatuur en testen op het blijven voldoen aan alle (veiligheids-)eisen krijgt vaak (te) weinig aandacht volgens enkele ondervraagden (bouwadviesbureaus, gemeente). 
'Bijvoorbeeld in het geval van chemische luchtwassers die een corrosief effect hebben op de omgeving en op de installatie zelf'.

* Zelf installeren van 'onveilige' apparatuur of uitbreidingen met als gevolg overbelasting van kabels/groepen vinden meerdere ondervraagden met name op kleine bestaande bedrijven nog steeds een risicofactor. Aangegeven is dat de gemiddelde ondernemer dergelijke installaties vaak zelf uitvoert. Voorbeelden: lampen die direct op sandwichpanelen worden gemonteerd, een oude koelkast die wordt bijgeplaatst in de technische ruimte. Men geeft aan dat grote ondernemers (de schaalvergroters) vaak professionele bedrijven in schakelen; bij grotere bedrijven bepaalt vaak de verzekeraar wie onderhoud, keuringen en reparaties mag uitvoeren.

* Er is geen verandering geconstateerd in de plaats van de stalling van werktuigen zoals tractoren en het risico op zelfontbranding ervan. Stalling gebeurt nog regelmatig in dezelfde ruimte als waar bijvoorbeeld stro is opgeslagen.

* Heaters worden volgens een bouwadviesbureau nog vaak toegepast in pluimveestallen. 'Een paar jaar terug nam centrale verwarming toe, maar dat is duurder en er zijn erkende goedkopere heaters, die daardoor ook nog vaak worden toegepast'.

* Brandgevaarlijke werkzaamheden zijn volgens de ondervraagden nog steeds belangrijke veroorzakers van stalbrand. De gemiddelde ondernemer voert volgens hen werkzaamheden zoals lassen en slijpen zelf uit. 'Het zit soms in kleine dingen (bijvoorbeeld een bouwlamp bij werkzaamheden die direct op brandbaar materiaal zoals isolatie wordt gezet)'. Maar ook bij uitvoering door professionele bedrijven gaat het soms mis. De grote verzekeraars nemen bij grootschalige projecten/nieuwbouwprojecten voorwaarden voor brandgevaarlijke werkzaamheden mee in de polis.

Door geïnterviewden genoemde verbetermogelijkheden:

- Alle stallen verplicht een elektrakeuring iedere 3-5 jaar

- In de varkenshouderij 1 luchtwasser per brandcompartiment of 1 luchtwasser tussen twee compartimenten $\rightarrow$ bouwadviseurs/stallenbouwers zouden moeten nadenken over hoe dit is te realiseren

- Bij centraal ventilatiekanaal voor meerdere afdelingen in de varkenshouderij $\rightarrow$ compartimentering van luchtkanalen

- Elektromotoren voor mest-/eierbanden buiten dierverblijven houden $\rightarrow$ in ontwerpfase van een stal meenemen

- Risicoapparatuur in de voorruimte van een pluimveestal plaatsen met sensoren en sprinklers [hoeft niet per se een brandcompartiment te zijn]

- Meer aandacht voor kwaliteit en ontwerp van apparatuur, wijze van aanleg, onderhoud en regelmatig toetsen of het nog steeds voldoet.

- Afgesloten schakelkasten voorzien van $\left(\mathrm{CO}_{2}\right)$-bluspatronen

- Gescheiden opslag stro/hooi van dierverblijf

- Gescheiden opslag stro/hooi en stalling van werktuigen (incl. grasmaaiers)

- $\quad$ Plak-dakbedekking (bv. EPDM) op platte daken (dan hoeft niet te worden gebrand)

- Elektromagnetische luiken die bij brand automatisch openen $\rightarrow$ natuurlijke luchtstroom creëren, te combineren met daglichtramen [is in UK verplicht wanneer er geen noodstroomvoorzieningen aanwezig is; mogelijk nadeel: koudebrug; en het vuur kan erdoor worden aangewakkerd]

- Milieu-inspecteur tijdens bedrijfsbezoek ook brandveiligheid laten checken als eyeopener voor de veehouder [bezoekfrequentie nu 1 keer per 5-10) jaar, dat wordt 1 keer per 3 jaar voor grote bedrijven]

- Nader onderzoek naar wat de echte brandrisico's zijn op bedrijven, bijvoorbeeld aan de hand van een risico-inventarisatie op een steekproef van 100 bedrijven. 


\subsection{Over snelle detectie}

Referentie [WUR/IFV-rapport 2012] Conclusie in 2012:

$\mathrm{Bij}$ brand in de huidige veestallen is het aantal dierlijke slachtoffers doorgaans groot. Dit hangt o.a. samen met:

- een relatief late detectie van brand. Het personele toezicht (de fysieke aanwezigheid) in stallen is beperkt en dit wordt als gevolg van de voortschrijdende procesautomatisering verder teruggedrongen. Betrouwbare reguliere branddetectiesystemen zijn in veestallen niet functioneel (de huidige apparatuur geeft veel vals-meldingen en er treedt aantasting van de apparatuur op als gevolg van stof en concentraties aan stalgassen zoals $\mathrm{NH}_{3}$ );

Door geïnterviewden genoemde ontwikkelingen in de afgelopen jaren:

* Er wordt door een verzekeraar enige toename gezien in de toepassing van branddetectie in de technische ruimte.

* Er zijn nog steeds geen goed functionerende branddetectiesystemen (rookmelders e.a.) voor in dierverblijven. Onder andere bouwbureaus en brandweer geven aan dat branddetectie in dierverblijven functioneert als het net nieuw is, maar dat de betrouwbaarheid snel in het geding komt door veroudering, slijtage en vervuiling/aantasting door stof, vocht en ammoniak.

* Temperatuurdetectie vinden o.a. verzekeraars zinvol, maar dat heeft dan vooral te maken met detectie van uitval van ventilatie en niet zozeer met brandveiligheid. Aan de meeste klimaatinstallaties kan volgens ondervraagden een brandalarm worden gekoppeld. Bouwadviesbureaus geven aan dat luchttemperatuursensoren te traag zijn om voor vroege branddetectie te gebruiken. De plek waar de klimaatsensoren zijn bevestigd (o.a. op dierniveau) is niet dezelfde plek is als waar de branddetectie zou moeten hangen.

* Diverse ondervraagden geven aan dat ook bij grootschalige bedrijven in de regel geen rookof branddetectie wordt toegepast. In het kader van gelijkwaardigheid wordt volgens een brandweer en een gemeente op papier nog wel eens met rookdetectie gewerkt, bijvoorbeeld in combinatie met een brandwerend rolluik tussen twee brandcompartimenten, dat sluit bij aanslaan van rookmelders; in de praktijk zijn die rookmelders volgens hen na enkele weken door ammoniakuitstoot of stof onwerkbaar geworden en de vraag is of ze dan vervangen worden.

* Steeds meer stallen zoals bij vleesvarkens zijn onbemenst ${ }^{2}$. Een bouwadviesbureau geeft aan dat eker eigenaren van onbemenste stallen op zoek zijn naar andere branddetectiesystemen dan rookmelders, die tijdig kunnen waarschuwen.

* De meeste ondervraagden zien weinig toegevoegde waarde in meer aandacht voor snelle detectie. men geeft aan dat gecontroleerd laten uitbranden en het voorkómen van overslag naar belendingen voor de brandweer vaak de enige optie is, de dieren zijn als gevolg van rookontwikkeling en giftige dampen al snel niet meer te redden. 'Richt je op voorkómen (installaties, werkzaamheden). Voordat de rook bovenin zo'n grote stal is, ben je al te laat'.

\section{Door geïnterviewden genoemde verbetermogelijkheden:}

- Detectie in combinatie met een sprinklersysteem [de meningen over het nut van sprinklers zijn verdeeld, ook vanwege de hoge kosten; men denkt dat het in elk geval nuttig kan zijn in de technische ruimte]

- Innovaties in branddetectie bevorderen, die eenvoudig te onderhouden zijn [wordt nog belangrijker bij onbemenste stallen]. Bij onbemenste stallen neemt de ontwikkeling van camerasystemen toe. Deze zijn mogelijk te koppelen met softwarematige toevoeging van een branddetectiesysteem.

\footnotetext{
${ }^{2}$ Hiermee bedoelen we stallen waar niet de hele dag een persoon aanwezig is en/of stallen waar de ondernemer zelf niet naast woont.
} 


\subsection{Over branduitbreiding}

Referentie [WUR/IFV-rapport 2012] Conclusie in 2012:

$\mathrm{Bij}$ brand in de huidige veestallen is het aantal dierlijke slachtoffers doorgaans groot. Dit hangt o.a. samen met: - de gebruikte materialen voor dak- en plafondisolatie en voor hokinrichting (inclusief mest- en eiertransportbanden). Door deze materialen kan een brand zich zeer snel door de stal uitbreiden, hetgeen vaak gepaard gaat met veel en/of giftige rook en gassen en veel energieontwikkeling. Door deze snelheid kan de brandweer bij aankomst in veel gevallen weinig meer doen om dierenleed te verminderen;

- de afsluiting van ventilatiekanalen of afsluiting c.q. uitvallen van de stroom, waardoor bij toepassing van mechanische ventilatie of systemen met centrale luchtafzuiging over meerdere brandcompartimenten ook dieren in naastgelegen compartimenten verstikken.

- en in enkele gevallen de onderlinge situering van stallen en de positie van luchtinlaten, die er toe kunnen leiden dat ook dieren in belendende stallen het slachtoffer worden (via inademen van rook, hete lucht).

Door geïnterviewden genoemde ontwikkelingen in de afgelopen jaren:

* De gewijzigde eisen die met ingang van 1-4-2014 in het Bouwbesluit zijn gesteld aan bij nieuwbouw te gebruiken materialen (brandklasse B constructiematerialen) worden door alle geïnterviewden als een belangrijke vooruitgang gezien. Er wordt wel een kanttekening geplaatst: er zijn op dit moment nog maar weinig stallen volgens het gewijzigde Bouwbesluit (1-4-2014) gebouwd. Tevens geeft men aan dat de wijze van monteren de brandklasse van het gebruikte materiaal teniet kan doen. En dat soms ook andere materialen worden toegepast dan in de vergunningaanvraag is opgenomen. 'Geen aannemer bouwt $100 \%$ zoals het was aangegeven'. de wens tot kostenbesparing kan daar een rol in spelen. De gemeenten geven aan hier wisselend op te controleren. Bij oplevering is niet altijd meer zichtbaar welke materialen zijn gebruikt, gemeenten geven aan alleen verder kijken als er ernstige vermoedens van onrechtmatigheden zijn.

* Vanuit risicogericht denken valt er volgens meerdere ondervraagden geen winst te behalen op het verbieden van houten gordingen in dakconstructies, zoals nu formeel het geval is op grond van het nieuwe Bouwbesluit. In de praktijk worden vaak houten gordingen toegepast en door de gemeenten toegestaan binnen de $5 \%$ afwijkingsregel. Het belang vindt men zitten in de brandklasse van het isolatiemateriaal; de gording doet er feitelijk niet toe.

* De hokinrichting valt buiten de eis van brandklasse B in het nieuwe Bouwbesluit. Bouwadviesbureaus en gemeenten/brandweer geven aan dat op varkensbedrijven veel gebruik wordt gemaakt van kunststoffen scheidingswanden. Dit betreft vooral niet-dragende scheidingsmuren tussen afdelingen.

* De beperkingen aan de omvang van het bouwblok, en daarmee de situering en onderlinge afstand van stallen ten opzichte van elkaar, plaatsing van luchtwassers, opslag van mest en materialen en stalling van werktuigen e.d. vormen volgens enkele ondervraagden in toenemende mate een knelpunt uit oogpunt van brandveiligheid. Men geeft aan dat in de intensieve veehouderij oude stallen vaak worden gesloopt en nieuw gebouwd. In de melkveehouderij wordt vaak, als de situatie het toelaat, bijgebouwd in de lengterichting van een bestaande stal of ernaast, tegen de bestaande stal aan. In de lengterichting aanbouwen komt ook voor in de varkenshouderij, niet in de pluimveehouderij. Door beperkingen aan het bouwblok worden stallen bij nieuwbouw dichter bij elkaar geplaatst, brandoverslag door hittestraling wordt zo een groter risico, ook indien sprake is van aparte brandcompartimenten. Verzekeraars vragen in dat geval om een brandwerende scheiding tussen compartimenten. Het komt regelmatig voor dat verschillende stallen of nieuwe aanbouw samen met de bestaande stal als één brandcompartiment worden opgevoerd.

* In de varkenshouderij plaatst men uit kostenoverwegingen vaak één grote centrale luchtwasser tussen verschillende naast of aan elkaar gelegen stallen of brandcompartimenten. Dit is volgens de bouwadviesbureaus bij brand een kwetsbaar systeem voor dieren in de aangrenzende dierverblijven.

* Men geeft aan dat het in de praktijk van de pluimveehouderij lastig is om voer-, mest- en eierbanden mee te nemen in de compartimentering. Wel geeft een brandweer aan in de praktijk steeds meer minder brandbare mest(dwarsafvoer)- en eierbanden te zien. Deze worden ook steeds vaker toegepast in bestaande stallen.

* In het beperken van branduitbreiding in bestaande stallen met oude isolatie is volgens de ondervraagden niets veranderd. Een verzekeraar geeft aan dat asbestsanering alleen gebeurt als het moet (uiterlijk 2024), en dan wordt isolatie niet meegepakt. Veel bedrijven hebben geen geld voor sanering, laat staan voor aanpassen van isolatie. Bij 10-15 jaar oude stallen werd in het verleden alles aan elkaar vast gebouwd, één groot brandcompartiment, daar is nu 
niets meer aan te doen, en daar gaat de asbestsanering ook niet bij helpen. Beperken van risico op ontstaan van brand is hier de enige mogelijkheid zolang deze stallen worden gebruikt.

Door geïnterviewden genoemde verbetermogelijkheden:

- Houten gordingen toestaan

- Ook eisen stellen aan brandklasse van materialen die gebruikt worden voor hokinrichting. Bij varkens wordt veel kunststof gebruikt. Bij eisen aan hokinrichting aandacht besteden aan verschillen in risico's tussen sectoren

- Minder brandbare mest-/eierbanden

- Branddetectie en sprinklers aan weerskanten van doorgangen waar mest-/eierbanden brandwerende muren doorsnijden

- Voor de varkenshouderij: ieder brandcompartiment zou een aparte luchtwasser moeten hebben. Of anders een goede scheiding realiseren, ook in de luchtkanalen

- Handvatten geven voor interpretatie van de eisen van het Bouwbesluit aan tussenwanden in de varkenshouderij [wanden die bedoeld zijn om klimaatgescheiden ruimtes te creëren, geen dragende constructies]

- Grotere bouwblokken in de toekomst? Bijvoorbeeld flexibele bouwblokken met een limitering van het te bebouwen oppervlak

\subsection{Over blussen}

Referentie [WUR/IFV-rapport 2012] Conclusie in 2012:

De bepaling over aanwezigheid van een door de ondernemer zelf aan te leggen bluswatervoorziening bij ontbreken van een openbare voorziening wordt naar verwachting niet altijd nageleefd. Diverse geïnterviewden geven aan dat de aanwezigheid van bluswater op het platteland vaak een knelpunt vormt. Dit wil niet wil zeggen dat dit het verloop van een stalbrand voor de betrokken dieren in negatieve zin heeft beïnvloed. In veel gevallen kan de brandweer bij aankomst de betreffende stal nog slechts uitbreiding en overslag naar andere gebouwen voorkomen. Beschikbaarheid van voldoende bluswater speelt hierbij wel een belangrijke rol.

Door geïnterviewden genoemde ontwikkelingen in de afgelopen jaren:

* Een gemeente geeft aan dat er bij nieuwbouw steeds meer aandacht is voor de aanwezigheid van kleine blusmiddelen. Ook bij bepaalde bestaande stallen vanwege milieuregelgeving (Activiteitenbesluit/Omgevingsvergunning). Meerdere ondervraagden benadrukken dat handblussers vooral bedoeld zijn voor het blussen van kleine, lokale brandjes, bij grotere branden of uitbraak hoog in de stal (bijvoorbeeld bij de ventilatoren) ben je altijd te laat. En handblusmiddelen zijn alleen effectief als er mensen aanwezig zijn; de kans op blussen van een nog lokale brand buiten werktijd in een grotendeels onbemenste stal vindt men nihil. De bouwadviesbureaus benadrukken de praktische nadelen van brandslanghaspels in stallen/dierverblijven: ze zijn vorst- en corrosiegevoelig.

* De verzekeraars uiten hun zorg over de beschikbaarheid van bluswater . Waterpunten vanuit het openbare waternet nemen af in het buitengebied. Verzekeraars worden zelf kritischer op de noodzakelijke aanwezigheid van een bluswatervoorziening op het erf. Een gemeente geeft aan dat het onderwerp secundaire bluswatervoorzieningen al enkele jaren op de agenda staat: vanwege het kostenaspect is het niet overal op orde. Er wordt door de brandweer enige investering gedaan in tankwagens. De brandweer probeert steeds meer mee te denken (via de adviseurs, steeds minder rechtstreeks met de ondernemer) over de aanwezigheid van bluswater bij grote stallen: handige locatie voor put of (infiltratie)vijver. En geeft aan dat voorzieningen zoals waterpunten wel dagelijks gebruikt moeten worden, anders is de kans groot dat het mis gaat op het moment dat bluswater nodig is.

* Door reorganisatie van de brandweer is het werkgebied groter geworden, waardoor door ondervraagden de zorg wordt geuit dat ook de aanrijtijden toenemen.

* Er zijn geen ontwikkelingen op het gebied van automatische blusinstallaties geweest. Er wordt wisselend gedacht over het nut van sprinklers. De een noemt het een toekomstideaal, de ander ziet er weinig nut in. Allen noemen de hoge kosten als bezwaar. Sommigen zien enig heil in mistsystemen, die zijn in Duitsland en Scandinavië vaak te zien. Ook mistsystemen werken alleen bij een goede detectie, maar worden vaak toegepast in combinatie met klimaatbeheersing voor koeling voor vee en andere doeleinden zoals inweken en 
schoonmaken van stallen. Combinatie van automatische blussystemen met systemen die dagelijks gebruikt worden, vergroot volgens ondervraagden de acceptatie en daardoor de toepassing.

* Blussystemen worden een enkele keer specifiek gekoppeld aan bepaalde apparaten of techniek. Zo ziet een verzekeraar soms schakelkasten met rookdetectie en $\mathrm{CO}_{2}$-bluspatronen.

* Een brandweer ziet bij onbemenste stallen de ontwikkeling van camerasystemen toenemen en denkt dat dit (in de toekomst) mogelijkheden kan bieden voor (vroege) branddetectie.

Door geïnterviewden genoemde verbetermogelijkheden:

- Schakelkasten voorzien van bluspatronen

- Eisen aan brandslanghaspels nuanceren: niet zinvol in corrosieve of niet-vorstvrije omgeving. Corrosiebestendig maken van haspels kan wel zinvol zijn

- Toepassing sprinkler-/mistsystemen met meerdere doelen bevorderen: inweken, vernevelen

- Watergordijn tussen stallen die dicht bij elkaar staan [wel forse pomp en fors waterbassin nodig]

- Infiltratievijver (in kader van verplichte watertoets voor grote ontwikkelende bedrijven) benutten als voorraadbassin voor aanwezigheid van bluswater

- Grotere bouwblokken met goede routing/ruimte voor blusvoertuigen

- Objectinformatiekaart ten behoeve van de brandweer

\subsection{Over evacuatie en/of snelle euthanasie van dieren}

Referentie [WUR/IFV-rapport 2012] Conclusie in 2012:

Productiedieren in veehouderijsystemen zijn niet zelfredzaam en in geval van stalbrand ( $m$. $n$. in intensieve

veehouderijsystemen) doorgaans niet te redden. Dit is een belangrijk verschil met humane instellingen waar nietzelfredzame personen verblijven. De niet-zelfredzaamheid van dieren en de geringe evacuatiemogelijkheden moeten uitgangspunt zijn voor het doorvoeren van verbetermaatregelen voor brandveiligheid in veestallen.

Om dierenleed te beperken, dienen niet meer te redden dieren tijdens een stalbrand zo snel mogelijk te worden gedood. Diervriendelijke, koppelgewijze dodingsmethoden zijn niet voorhanden of onvoldoende bekend. Massale euthanasie tijdens stalbrand kan op maatschappelijke weerstand stuiten.

Door geïnterviewden genoemde ontwikkelingen in de afgelopen jaren:

* Er zijn volgens de ondervraagden geen (positieve) veranderingen geweest in de afgelopen jaren in de mogelijkheden voor evacuatie van dieren bij stalbrand. Men benadrukt dat dieren in intensieve houderijsystemen doorgaans niet zijn te redden. En als ze al gered worden, is het zeer de vraag of ze in de periode erna de stress, klimaatwisseling en eventueel rookschade overleven. Melkgeiten en koeien en andere dieren die weidegang gewend zijn, zijn mogelijk wel te evacueren. Men vindt het in de intensieve veehouderij vooral belangrijk om aandacht geven aan preventie van vuuroverslag naar een ander brandcompartiment en zorgen dat de dieren daar in leven blijven.

* Een verzekeraar geeft aan dat de tendens om bij nieuwbouw bestaande melkveestallen te verlengen, de evacuatiemogelijkheden van deze dieren bij brand vermindert.

* Er worden geen ontwikkelingen in de praktijk gezien op het gebied van rookwarmteafvoer (RWA).

* Ook op het gebied van diervriendelijke, koppelgewijze dodingsmethoden voor niet te redden dieren in een stalbrand zien de geïnterviewden geen ontwikkelingen in de praktijk. Koppelgewijs doden van pluimvee met $\mathrm{CO}_{2}$, zoals wel gebeurt bij dierziektencalamiteiten, zou volgens een ondervraagde misschien mogelijkheden kunnen bieden, omdat men gelijker tijd de brand ermee blust.

* Een brandweer geeft aan dat vrijkomen van asbest een snelle euthanasie door dierenartsen van niet te redden dieren soms kan belemmeren.

Door geïnterviewden genoemde verbetermogelijkheden:

- Zelfopenende deuren/luiken? Deze zouden echter ook kunnen zorgen voor zuurstofaanvoer en op die manier de brand aanwakkeren. Systemen zijn niet praktijkrijp.

- En: er zijn geen echte oplossingsrichtingen voor evacuatie van dieren in intensieve systemen 


\subsection{Over grote brandcompartimenten $\left(>2.500 \mathrm{~m}^{2}\right)$}

Referentie [WUR/IFV-rapport 2012] Conclusie in 2012:

De Leidraad Beheersbaarheid van Brand, binnen het Bouwbesluit 2012 alleen nog door sommige gemeenten toegepast voor aantonen van 'gelijkwaardigheid' voor stallen $>2.500 \mathrm{~m}^{2}$, heeft geen toegevoegde waarde voor de veiligheid van dieren in veestallen. De vuurlastgrenzen (hoeveelheid verbrandingsenergie) binnen de Leidraad zijn zodanig ruim dat ook veestallen met zeer grote brandcompartimenten er relatief eenvoudig aan kunnen voldoen. Het ontbreken van eenduidige specifieke regelgeving voor brandveiligheid van veestallen (rijksoverheid) dan wel overeengekomen richtlijnen (VNG) bevordert, door de interpretatieruimte die gemeenten en brandweer nemen, een zekere rechtsongelijkheid tussen veehouders die in een verschillende gemeente hun bedrijf voeren.

Door geïnterviewden genoemde ontwikkelingen in de afgelopen jaren:

* De gemeenten geven aan dat er nog steeds landelijke handvatten ontbreken voor het aantonen van gelijkwaardigheid van grotere brandcompartimenten ontbreken. De in ontwikkeling zijnde bijlage voor veestallen bij de bestaande NEN-normen moet hier verandering in brengen. Gemeenten geven nog steeds uiteenlopend invulling aan de eisen voor gelijkwaardigheid. Sommige gemeenten accepteren vanwege het ontbreken van handvatten voor gelijkwaardigheid op dit moment helemaal geen bouwaanvragen voor stallen $>2.500 \mathrm{~m}^{2}$.

* In de betrokkenheid van verzekeraars is weinig veranderd ten opzichte van 4-5 jaren geleden. Een geïnterviewde verzekeraar is nog steeds betrokken bij de ontwerpfase van grote projecten, er wordt gekeken naar elektra, regels voor brandveiligheid en omvang. De andere verzekeraar komt bij oplevering in beeld. Beiden benadrukken dat het bij de (grote) bouwprojecten niet gaat om aantal dieren of dierenleed, maar om het economisch belang: de bedrijfscontinuïteit en de financiële borging. Maximale bedrijfsomvang is voor verzekeraars niet het maximale aantal dieren of vierkante meters, maar afgestemd op de maximale kosten van herbouw, inrichting en ingebruikname na brand. Men vindt het aan de politiek om aan te geven hoeveel dierlijke slachtoffers per stalbrand maximaal toelaatbaar zijn.

* Een gemeente en brandweer geven aan dat gelijkwaardigheid op papier vaak mooi wordt beschreven door bouwadviseurs namens ondernemers. In de praktijk is het lastig inschatten wat beschreven organisatorische maatregelen zoals stofvrij houden van stallen of de toezegging van brandveilig werken daadwerkelijk bijdragen.

* Vee wordt niet meegenomen in vuurlastberekening van grote stallen (gelijkwaardigheid). Een grote verzekeraar geeft aan dat dit wel gewenst is.

* De geïnterviewden hebben geen ontwikkelingen in het bouwen van stallen met meerdere verdiepingen waargenomen in de afgelopen jaren. De meeste bestemmingsplannen staan dat tegenwoordig volgens hen ook niet meer toe.

Door geïnterviewden genoemde verbetermogelijkheden:

- Een grote verzekeraar geeft aan na te denken over inzetten van brandklasse A bij hele grote brandcompartimenten in de toekomst.

- Compartimentering passend bij de werkelijke vuurlast zou volgens een verzekeraar beter zijn dan de huidige aanpak: het gaat dan niet over kansreductie, maar over effect beperken.

\subsection{Over houdingsveranderingen}

Referentie [WUR/IFV-rapport 2012] Conclusie in 2012:

Het bewustzijn en de kennis van veehouders ten aanzien van brandveiligheid kan in het algemeen hoger/beter. Voor veel veehouders en hun erfbetreders, financiers en andere actoren lijkt brandveiligheid van veestallen geen issue. De kans op brand wordt laag ingeschat en vooral verbonden aan brandgevaarlijke werkzaamheden. Het vertrouwen in de veiligheid van de technische installaties en de bestrijdingsmogelijkheden van de brandweer is groot. Door toenemende druk vanuit verzekeraars neemt de bewustwording wel toe.

Door geïnterviewden genoemde ontwikkelingen in de afgelopen jaren:

* Bewustzijn van brandveiligheid is bij bepaalde ondernemers in de afgelopen jaren volgens de ondervraagden toegenomen. Verzekeraars zien een houdingsverandering rondom de elektrakeuringen. Verbinden van elektrakeuring aan verlengen van de brandverzekering is een goedwerkende incentive voor het uitvoeren van deze keuringen. Meerdere ondervraagden geven aan dat het belangrijk is om alert te blijven, want kostenbesparing beïnvloedt vaak de keuze. De hoeveelheid regels waaraan veehouders moeten voldoen en de slechte verdiensten 
in de afgelopen jaren beperken de aandacht voor brandveiligheid. Soms is men er ook niet mee bezig uit onwetendheid. De zorg voor de veiligheid van de dieren moet volgens diverse ondervraagden nog meer landen.

* Bewustzijn van brandveiligheid is sterk gekoppeld aan het type ondernemer. In de interviews worden in relatie met de attitude ten aanzien van brandveiligheid min of meer de volgende typen ondernemers onderscheiden:

- De ondernemer zonder toekomstperspectief, met verouderde stallen. Niet gericht op brandveiligheid, alleen aanspreekbaar als veranderingen worden afgedwongen, zoals periodieke elektrakeuring door verzekeraar. Brandveiligheid voor dieren is op zichzelf geen kwestie [red.: dit zouden we de uitfaseerder kunnen noemen]

- De bewust kleinschalig producerende ondernemer, vaak biologisch, met uitloopsystemen, multifunctionele landbouw, zorgboerderij e.d. Aandacht voor mens en dier past van nature al iets meer bij deze ondernemer [red.: dit zouden we de verbreder kunnen noemen] Vooral de verbreders hebben volgens enkele ondervraagden veel ogen die meekijken: GGD, Arbodienst.

- De (relatief jonge) grootschalige ondernemer, bezig met bedrijfsontwikkeling en in toenemende mate manager van meerdere vestigingen. Brandveiligheid voor dieren is op zichzelf geen kwestie. Wel meer bewust van het belang van brandveilige stallen en brandveilig werken, vanwege de economische belangen, continuïteit waarborgen in geval van stalbrand. Daar lift de brandveiligheid voor dieren op mee [red.: dit zouden we de schaalvergroter kunnen noemen]

* Verzekeraars geven aan dat de gemiddelde veehouder zich doorgaans niet erg bewust is van het risico van gevolgschade, een afgebrande stal bouw je niet zo maar terug. De gevolgschade is vaak groter dan de directe schade. Ondernemers die zelf met brand zijn geconfronteerd, zijn daarna volgens meerdere ondervraagden bewuster bezig met brandveiligheid.

* Veehouders die met bedrijfsontwikkeling bezig zijn en bouwers weten volgens een bouwadviesbureau door de verschillende rapporten over brandveiligheid nu heel goed wat de crux is en wat belangrijk is voor brandveiligheid. 'Als een opdrachtgever uit kostenbesparing toch af wil wijken van het plan, dan kan dat altijd, maar dat is dan het risico dat hij zelf wil lopen'.

* Een bouwadviesbureau noemt dat veehouders zich hebben gebogen over wat er nu al gedaan kan worden aan brandveiligheid zonder dat het geld kost. Daar kwamen oplossingen uit zoals lassen in de ruimte naast de dierverblijven, kabelgoten stofvrij en schoon houden, met een infraroodcamera de stroomkabels en elektromotoren checken op risicoplekken. Veehouders hebben door studiebijeenkomsten over brandveiligheid, o.a. van LTO, er een beter gevoel bij.

* De ondervraagden zien geen veranderingen in de attitude van aannemers: aannemers houden zich aan de regels van brandveiligheid als er voldoende toezicht is op naleving van de regels. Soms wordt uit praktische of financiële overwegingen gaandeweg de bouw van het plan afgeweken.

* Enkele ondervraagden geven aan dat er ook geen houdingsverandering is gezien bij de consument ten aanzien van brandveiligheid: er is nog geen duidelijke vraag vanuit de markt.

* Gemeenten geven aan dat het lastig is om politici mee te krijgen in een houdingsverandering. Milieu leeft op regionaal niveau meer dan dierenwelzijn. Genoemd wordt dat milieuregelgeving mogelijk een sterkere kapstok is voor toezicht op brandveiligheid dan het Bouwbesluit. Daar zitten diverse raakvlakken met brandveiligheid (bv. elektromotoren in stallen, opslag (brand)gevaarlijke stoffen).

Door geïnterviewden genoemde verbetermogelijkheden:

- Milieu-inspecteur inzetten voor toets van en advies over brandveiligheid tijdens milieuinspecties op bedrijven

- Brandveiligheid koppelen aan ketenconcepten, en via die weg een sterke incentive realiseren

- Aandacht voor brandveiligheid in het agrarisch onderwijs om toekomstige veehouders bewust te maken en van kennis te voorzien

- Regelmatig berichten over veehouders die goed presteren op gebied van brandveiligheid in vakbladen Boerderij, V-Focus etc. plaatsen, als vorm van publieke pluim van de brandweer 
In figuur 5.1 zijn kenmerken en attitudes samengevat van de actoren die op een of andere wijze betrokken zijn bij de brandveiligheid van (dieren in) veestallen. Het schema geeft een samenvatting van kenmerken en attitudes van actoren die zijn afgeleid uit de resultaten van de interviews.

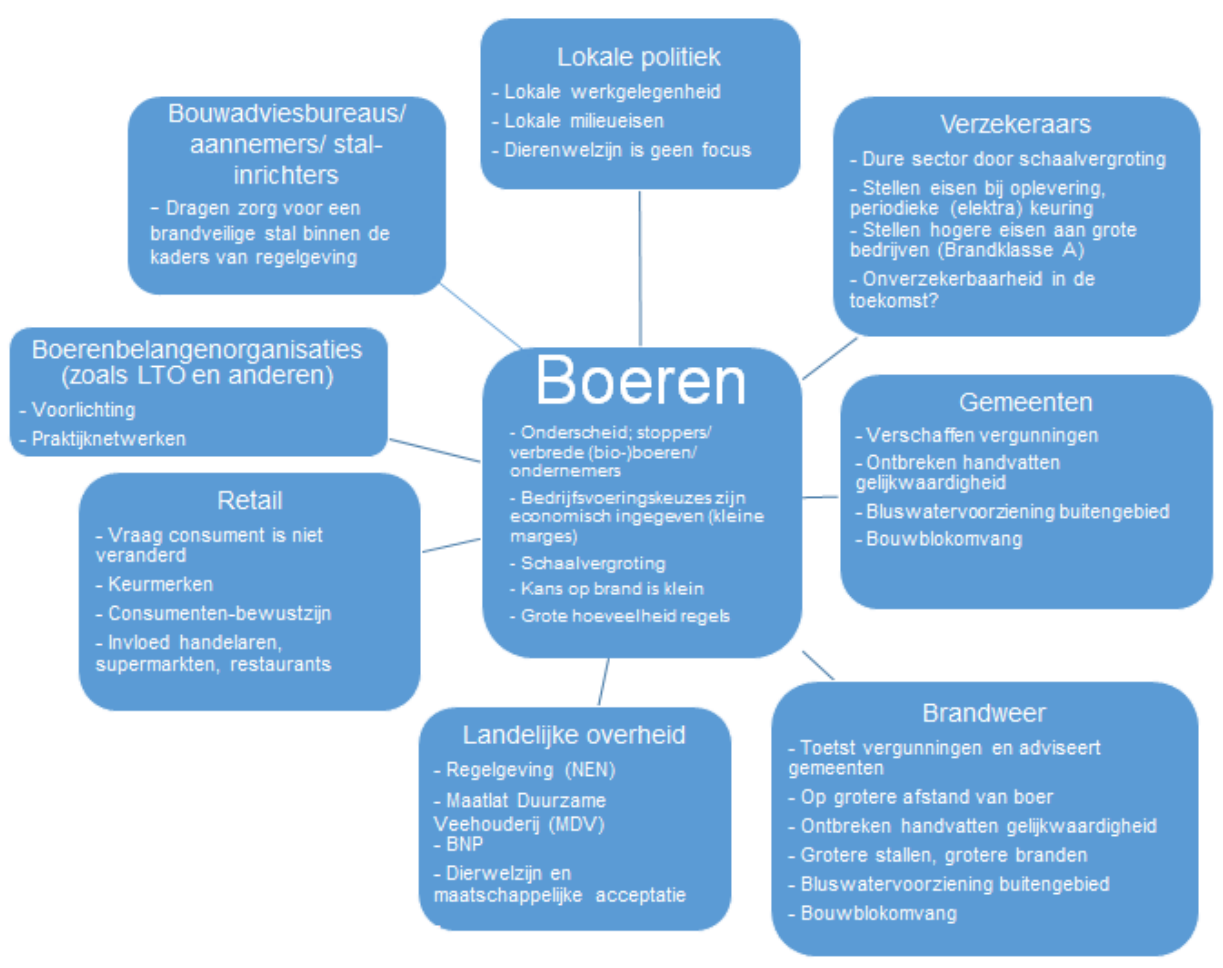

Figuur 5.1 Kenmerken en attitudes van actoren ten opzichte van brandveiligheid samengevat

Verzekeraars met hun eisenpakket rondom brandverzekeringen en private kwaliteitssystemen lijken belangrijke instrumenten te bieden om verbeteringen in een brandveilige bedrijfsvoering en brandveilige stallen af te dwingen, zowel voor bestaande stallen als bij en na nieuwbouw.

\subsection{Over toekomstige ontwikkelingen}

Referentie [WUR/IFV-rapport 2012] Conclusie in 2012:

Schaalvergroting binnen de veehouderij werkt zowel een toename in aantal dieren per locatie als een verdergaande automatisering van bedrijfsprocessen in de hand, waardoor niet alleen de impact, maar ook het aantal potentiële veroorzakers van stalbrand kan toenemen. Dit versterkt de noodzaak om de mogelijke oorzaken van ontstaan en uitbreiding van stalbrand aan te pakken en zodoende de risico's voor de dieren te verminderen.

Door geïnterviewden voorziene ontwikkelingen:

* Schaalvergroting gaat onverminderd door in de veehouderij. Hierdoor neemt volgens de ondervraagden enerzijds het aantal potentiele veroorzakers van stalbranden toe (meer techniek in de stal) en kunnen per incident meer dieren omkomen, anderzijds verdwijnen brandonveilige, verouderde stallen (o.a. brandbare isolatie). Daarnaast blijven kleinschalige, meer regionaal producerende bedrijven bestaan, die bewuster kijken naar veiligheid mens en dier.

* Een bouwadviesbureau ziet in de toekomst een behoefte aan grotere brandcompartimenten: de lijn naar steeds grotere eenheden zet door.

* Vanwege schaalvergroting worden ondernemers volgens meerdere ondervraagden steeds professioneler, met meer aandacht voor brandveiligheid, er worden minder concessies gedaan ['uit economische overwegingen, niet direct vanwege dierenwelzijn, maar dierenwelzijn lift wel mee']. 
* Vanwege welzijnsconcepten komen er meer overdekte uitlopen (pluimvee) bij bestaande stallen. Hiervoor wordt volgens meerdere ondervraagden de tussenruimte tussen stallen volgebouwd, met meer risico op overslag bij brand en minder goede bereikbaarheid in geval van blussen.

Men verwacht een toename van vlees- en eierconcepten die meer ruimte per dier, strooisel en buitenuitloop vragen. Tot nu is in innovatieve systemen weinig of geen aandacht geweest voor brandveiligheid. Voorbeeld Patiostal met 6 lagen, Rondeel met veel kunststof.

* Controles en vergunningverlening worden meer aan de markt overgelaten (geprivatiseerd). Daar hebben een gemeente en brandweer zorgen over en zetten er vraagtekens bij.

* De bouwblokgrootte wordt in bestemmingsplannen steeds meer begrensd. In combinatie met de voortgaande trend van schaalvergroting, leidt dit tot grotere stallen en minder ruimte tussen afzonderlijke stallen. Door meerdere ondervraagden wordt dit als een zorgpunt genoemd in verband met het risico op brandverspreiding en -overslag.

* Verzekeraars geven aan dat de verzekerbaarheid van grootschalige projecten in de toekomst onder druk kan komen te staan. Verzekeraars gaan volgens een bouwadviesbureau in de toekomst de looptijd van hun brandverzekeringen bekorten.

* Robotisering van werkzaamheden op de bedrijven zal verder toenemen (denk aan automatische melksystemen, voersystemen, mestrobotjes, voeraanschuifsystemen, melkverstrekkings-automaten). Dit vraagt extra aandacht voor brandveiligheid.

* Ook ontwikkelingen met betrekking tot warmtewinning, chemische luchtzuivering, fijnstofreductie, mestvergisting e.d. brengen volgens meerdere ondervraagden nieuwe risico's met zich mee.

* Er zullen steeds vaker zonnepanelen op staldaken worden geplaatst. Volgens een bouwadviesbureau is het onduidelijk of dit extra risico's voor brandveiligheid met zich meebrengt.

\subsection{Over de rol van het Actieplan}

In de interviews is gevraagd welke rol het Actieplan Stalbranden 2012-2016 heeft gespeeld in ontwikkelingen in brandveiligheid voor dieren in veestallen.

Het Actieplan is van invloed geweest, maar concreet aangeven welke invloed direct aan het Actieplan kan worden toegeschreven vindt men lastig. Toch zit er een duidelijke rode lijn in de antwoorden. En dat is dat het Actieplan zeker heeft bijgedragen aan de bewustwording van brandveiligheid en aan toedeling van verantwoordelijkheden (sectoren, verzekeraars, brandweer, overheden). De aandacht vanuit de sectoren zelf voor brandveiligheid van dieren in veestallen wordt als positief gezien. Ontwikkelende ondernemers zijn zeker bewuster geworden van het belang van brandveiligheid, o.a. vanwege de mogelijke economische gevolgen van brand. De verzekeraars spelen daar ook een stimulerende rol in. Bouwadviesbureaus zijn er in het opstellen van adviezen bewust mee bezig. Over het effect van het Actieplan op ondernemers met niet-ontwikkelende stallen zet men vraagtekens: die zijn doorgaans niet bewuster geworden, tenzij ze zelf met brand zijn geconfronteerd. Binnen het Actieplan hebben ondernemers in praktijknetwerken gewerkt aan praktische oplossingen voor vermindering van het risico op brand in bestaande stallen. Dat vinden enkele geïnterviewden een positieve ontwikkeling. Naast vergroten van het bewustzijn zijn de wijzigingen in het Bouwbesluit (heel) belangrijk geweest. Bij nieuwbouw is met voorschriften op gebied van technische ruimten en isolatiematerialen volgens ieder een flinke stap gezet. Veel aannemers zijn nog onvoldoende bereikt, nog onbewust en/of onwetend van het belang van brandveiligheid, waardoor de realisatie van nieuwbouw nog wel eens afwijkt van het plan. Het Actieplan mag van ondervraagden nog meer publiciteit krijgen in media en vakbladen.

In het volgende hoofdstuk is het resultaat weergegeven van de internetenquête onder veehouders naar attitude ten aanzien van brandveiligheid en de wijze uitvoering van brandgevaarlijke werkzaamheden. 


\section{Resultaat internetenquête onder veehouders}

Via de kanalen van LTO is er een internetenquête naar brandveilig werken uitgezet onder veehouders. De resultaten zijn hierna samengevat (zie ook bijlage 4 met overige responses in figuren uitgezet). In totaal zijn er 217 respondenten gestart met het invullen van de enquête: 24 pluimveehouders, 63 varkenshouders, 122 melkveehouders en 8 vleeskalverhouders. Het percentage respondenten per sector komt goed overeen met de landelijke verdeling van sectoren binnen de veehouderij (zie fig. 6.1). Van de 217 respondenten hebben 202 veehouders alle vragen ingevuld.
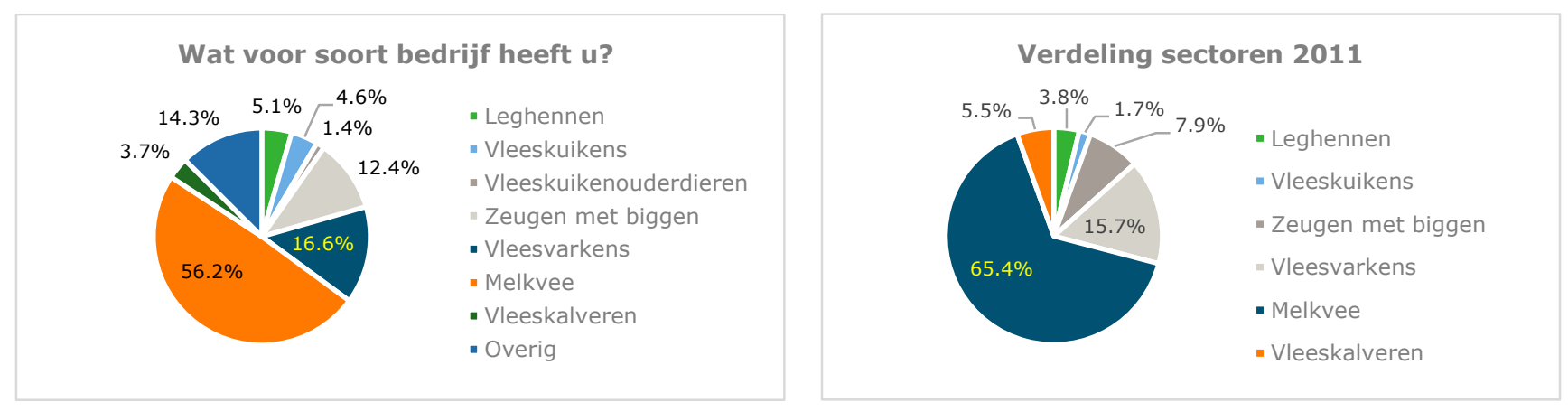

Figuur 6.1 Verdeling respondenten over de sectoren en landelijke verdeling sectoren in 2011 (bron: Landbouwtelling 2011)

De gemiddelde bedrijfsomvang van de respondenten per sector is een redelijke doorsnede van de landelijke gemiddelde bedrijfsgrootten (tabel 6.1).

Tabel 6.1 Bedrijfsomvang respondenten

\begin{tabular}{lll}
$\begin{array}{l}\text { Bedrijfsomvang } \\
\text { respondenten }\end{array}$ & N dieren & \\
& Gem. & Range \\
\hline Leghennen & 44.901 & $6-100.000$ \\
\hline Vleeskuikens & 47.000 & $21.000-100.000$ \\
\hline Vleeskuikenouderdieren & 30.750 & $23.000-40.000$ \\
\hline Zeugen met biggen & 1086 & $55-8000$ \\
\hline Vleesvarkens & 3055 & $125-7000$ \\
\hline Vleeskalveren & 957 & $40-3200$ \\
\hline Melkvee & 174 & $44-900$ \\
\hline Overig & 156 & $2-1500$ \\
\hline & &
\end{tabular}

Heeft $u$ in de afgelopen 5 jaar geïnvesteerd in stallen of bent $\mathrm{u}$ van plan dat in de komende jaren te doen?

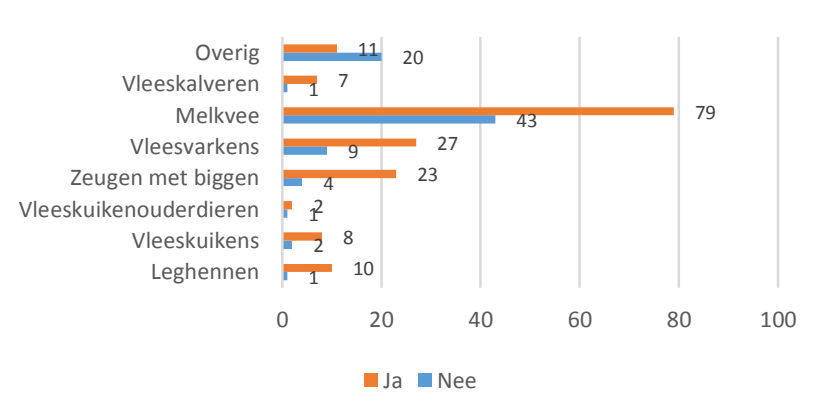

Figuur 6.3 Recente investering in eigen veestal

Meer dan de helft van de respondenten heeft in de afgelopen vijf jaar geïnvesteerd in het bedrijf of is van plan dat in de komende vijf jaar te doen. Circa $9 \%$ van de respondenten (van de 202) heeft in het verleden ervaring heeft gehad met brand in hun veestal(len) (waaronder 4 pluimvee-, 6 varkens- en 11 melkveebedrijven en 1 vleeskalverbedrijf). De oudste stalbrand van een respondent vond plaats in de jaren 70. Ervaring met stalbrand is mogelijk een extra stimulans geweest voor veehouders om de enquête in te vullen. 


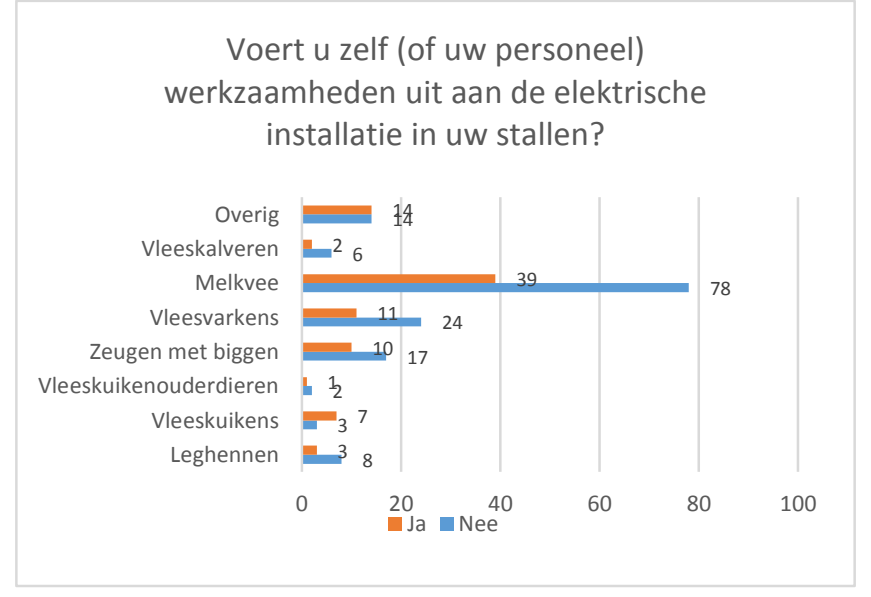

Figuur 6.4 Zelf werken aan elektrische installatie in stal

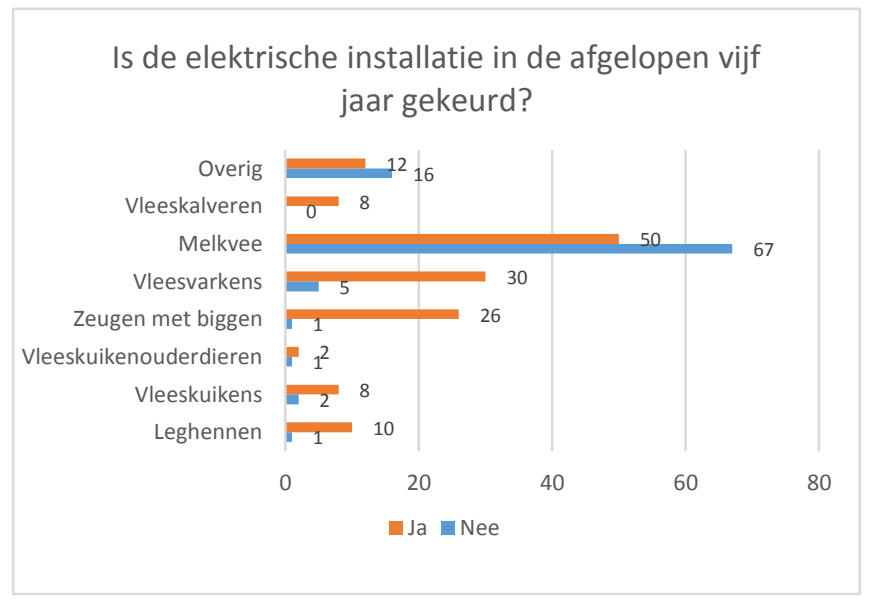

Figuur 6.5 Keuring elektrische installatie

Bij gemiddeld $37 \%$ van de respondenten voert de veehouder zelf of het personeel werkzaamheden uit aan de elektrische installatie in de stallen (fig. 6.4). Daaruit kunnen we ook opmaken dat op $63 \%$ van de bedrijven blijkbaar derden worden ingeschakeld als er reparaties met betrekking tot elektriciteit moeten worden uitgevoerd.

Op ruim 56\% van de bedrijven van de respondenten is de elektrische installatie in de afgelopen 5 jaar gekeurd (fig. 6.5). Het betreft vrijwel $100 \%$ van de pluimvee-, varkens- en vleeskalverbedrijven in de enquête. Onder de respondenten met melkveehouderij ligt dit percentage met ruim $40 \%$ duidelijk lager.

Ongeveer een derde van de respondenten geeft aan dat hun elektrische installatie en de onderdelen daarvan vrij zijn van stofophopingen. Circa $84 \%$ van de respondenten geeft aan dat de elektromotoren die in de stalruimtes aanwezig zijn beveiligd zijn tegen oververhitting.

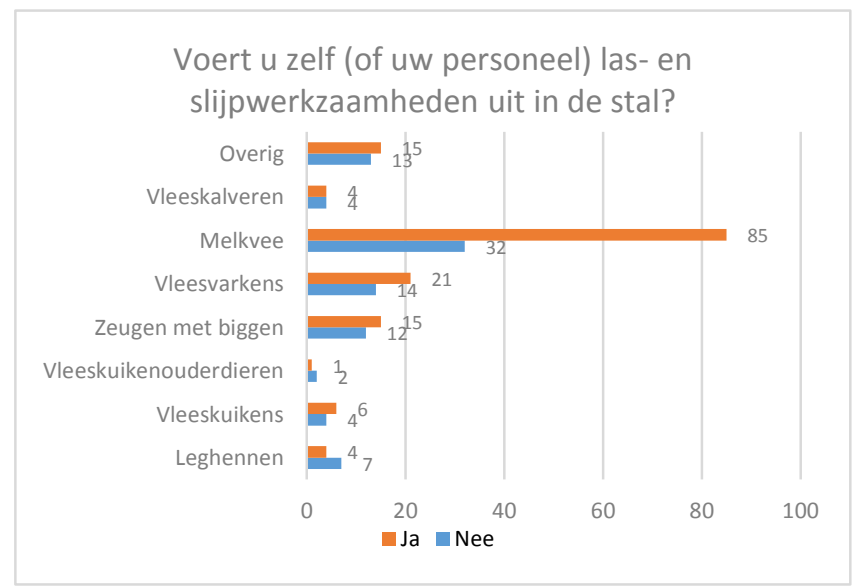

Figuur 6.6 Zelf uitvoeren las-/slijpwerk in stal

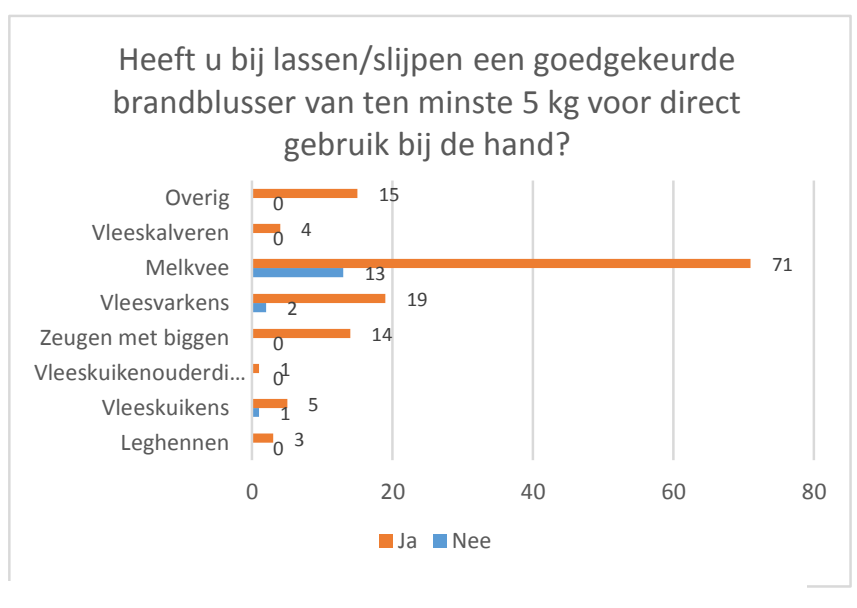

Figuur 6.7 Brandblusser bij las- en slijpwerk

○з\% van alle responaenten voert zelr Ias- en sıjpwerkzaamheden uit in de stal (fig. 6.6). In de melkveehouderij ligt dit percentage (met ruim 70\%) iets hoger dan in de intensieve sectoren (circa $55 \%$ ).

Bij deze werkzaamheden heeft men doorgaans een goedgekeurde brandblusser bij de hand ( $88 \%$ van de respondenten; fig. 6.7). Circa $15 \%$ van de melkveehouders onder respondenten vormt hierop een uitzondering. Slechts $10 \%$ van de respondenten houdt bij deze werkzaamheden ook een blusdeken bij de hand. Bij werkzaamheden geeft circa $90 \%$ van de respondenten aan brandbare stoffen tot op een veilige afstand van de plaats van de werkzaamheden te hebben verwijderd. Een kleine $40 \%$ van de respondenten dekt de roostervloer (mestput) in de nabijheid van de plaats van de werkzaamheden brandwerend af.

$\mathrm{Na}$ werkzaamheden controleert $95 \%$ van de respondenten of er niets smeult of kan gaan smeulen. 
Ongeveer $20 \%$ van de respondenten, verspreid over de verschillende sectoren, maakt gebruik van open verbrandingssystemen zoals gasheaters en warmtekanonnen.

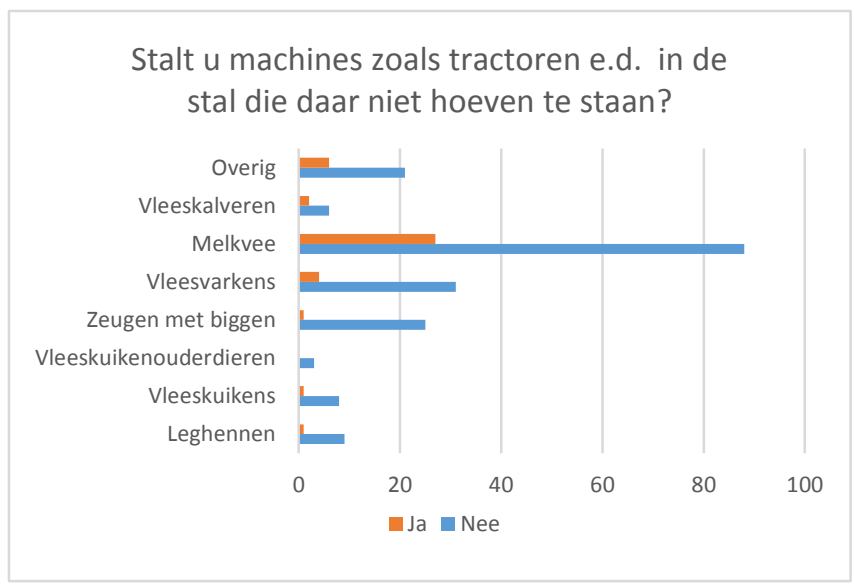

Circa $19 \%$ van de respondenten stalt machines zoals tractoren, shovels en grasmaaiers in de stal (fig. 6.8). Dit betreft zoals verwacht vooral veehouders met melkvee. Aangezien ruim 55\% van de respondenten melkveehouders is, geeft het merendeel van de melkveehouders (ruim $60 \%$ ) derhalve aan dergelijke brandgevaarlijke machines niet in de stal te parkeren.

Figuur 6.9 Goedgekeurde brandblussers in de stal
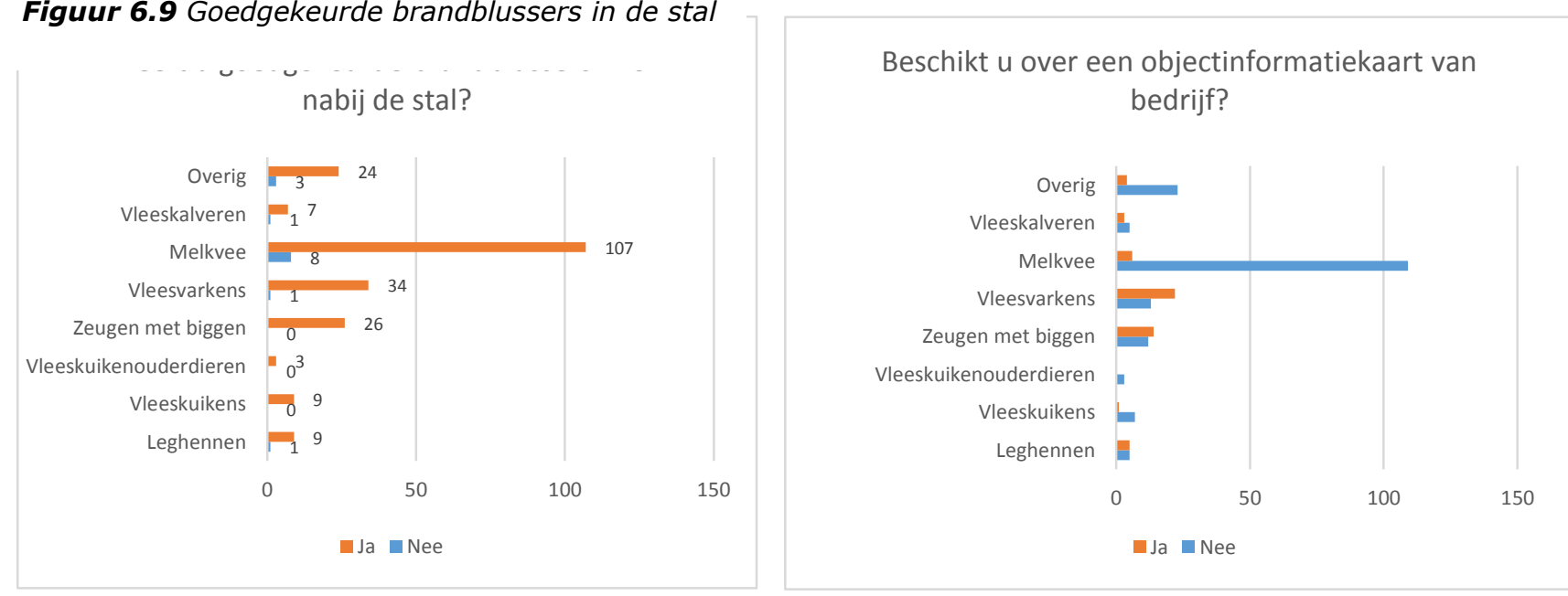

Figuur 6.10 Aanwezigheid objectinformatiekaart

Zo'n 93\% van de respondenten geeft aan een goedgekeurde brandblusser in of nabij de stal voorhanden te hebben (fig. 6.9). Op melkveebedrijven ontbreek dit soms. Van de 202 respondenten geeft $76 \%$ aan dat zij regelmatig controleren of er potentiële brandgevaren in de stal zijn, zoals stofvorming of broei. Een ander brandrisico wordt door 76\% van de respondenten beperkt: bij hen geldt een rookverbod in de stal. Een kleine $70 \%$ van de respondenten heeft geen personeel. Van de veehouders met personeel geeft $85 \%$ aan dat ze het personeel instrueert over brandrisico's en brandveilig werken. Op de vraag of er voldoende bluswater in de omgeving aanwezig is, antwoordt circa $84 \%$ van de respondenten positief.

Een kleine $20 \%$ van de respondenten geeft aan dat er een objectinformatiekaart voor de brandweer op het bedrijf aanwezig is (fig. 6.10). Dit betreft vooral veehouders binnen de intensieve sectoren; van de respondenten met melkvee geeft slechts $5 \%$ aan over een objectinformatiekaar te beschikken. 


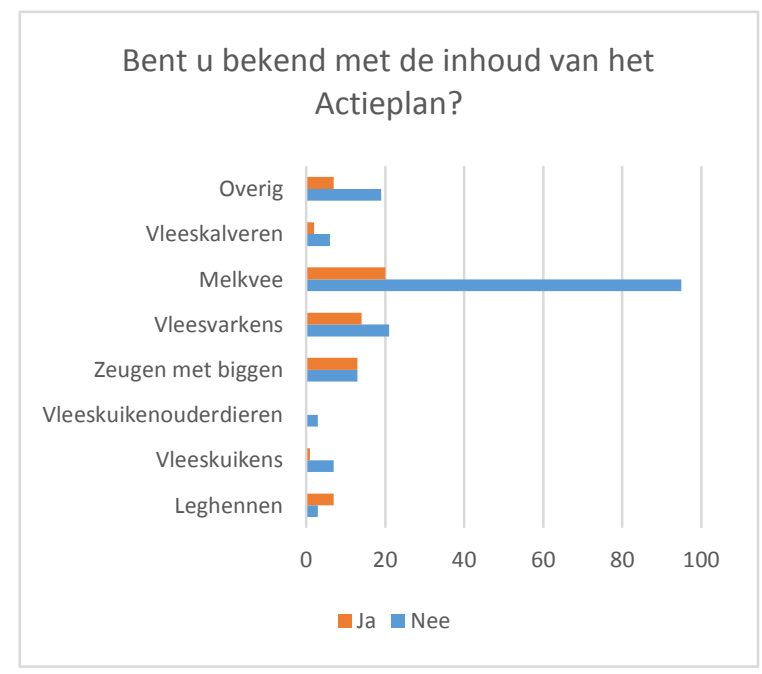

Heeft u gemerkt dat er extra aandacht is voor brandveiligheid de afgelopen jaren in de veehouderij?

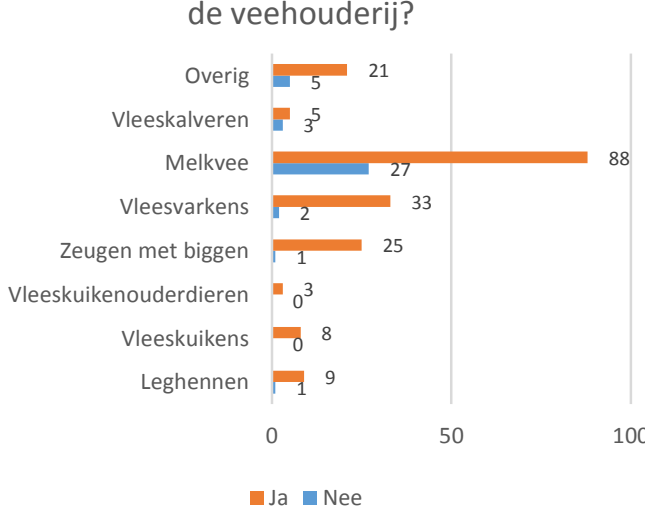

Figuur 6.11 Bekend met inhoud Actieplan

randveiligheid

Ruim $80 \%$ van de respondenten geeft aan gemerkt te hebben dat er in de afgelopen jaren extra aandacht is voor brandveiligheid in de veehouderij (fig. 6.12). Ongeveer $23 \%$ van de respondenten kent de inhoud van het Actieplan (fig. 6.11). Een koppeling tussen aandacht voor brandveiligheid en het actieplan lijkt niet vanzelfsprekend.

Van de 46 respondenten die aangeven de inhoud van het Actieplan te kennen, geven 31 personen aan dat het Actieplan hen nieuwe inzichten heeft gegeven op de risico's en preventie van stalbranden. Het merendeel van deze personen heeft er over gelezen in de vakpers, enkelen hebben erover gehoord van collega's en vijf respondenten hebben deelgenomen aan een bijeenkomst over stalbranden. 13 personen zijn er op nog andere wijze mee in aanraking gekomen, uiteenlopend van via contactpersoon bij de verzekering tot zelf lid te zijn van de brandweer.

\section{Samengevat}

Onder de respondenten lijkt er ten opzichte van de landelijke situatie een oververtegenwoordiging te zijn van veehouders die met bedrijfsontwikkeling bezig gaan of in de afgelopen 5 jaar bezig zijn geweest, en van veehouders die in het verleden met stalbrand te maken hebben gehad. Werk aan elektrische systemen wordt in zo'n 60\% van de gevallen aan professionals uitbesteed. Las- en slijpwerkzaamheden daarentegen gebeuren, zeker in de intensieve sectoren, vaak in eigen beheer. Daarbij worden meestal wel voorzorgsmaatregelen genomen (brandblusser paraat en dergelijke). Brandveilig afdekken van de mestput is daarbij nog geen gemeengoed (gebeurt op ca. $40 \%$ van de bedrijven). De enquête bevestigt het beeld uit de interviews dat op veel intensieve bedrijven recentelijk een elektrakeuring is uitgevoerd. De melkveehouderij blijft hierin nog enigszins achter, 
maar zal de komende jaren mogelijk een inhaalslag maken op aangeven van verzekeraars. Ook lijkt een belangrijk deel van de elektromotoren in dierverblijven inmiddels beveiligd te zijn tegen

oververhitting. Op een deel van de bedrijven (alle sectoren) worden nog open-vuur heaters toegepast. Een klein deel van de melkveehouders stalt nog steeds machines met gevaar op zelfontbranding in de stal. Aanwezigheid van een objectinformatiekaart voor de brandweer is op veel bedrijven nog niet gebruikelijk ( $20 \%$ van de respondenten, met name intensieve veehouders) beschikken er over.

Het is de respondenten zeker opgevallen dat er de laatste jaren meer aandacht is voor brandveiligheid in veestallen. Een relatie met het Actieplan wordt door circa een kwart van de veehouders gelegd. De vakpers is daarbij een belangrijk kanaal om veel veehouders te bereiken.

Het volgende hoofdstuk gaat in op (toekomstige) ontwikkelingen binnen sectoren die een relatie kunnen hebben met brandveiligheid van veestallen. 


\section{$7 \quad$ Ontwikkelingen binnen sectoren}

In dit hoofdstuk geven de onderzoekers een beschrijving van verwachte vervangingsritmes van ruwbouw, stalinrichting en technische installaties, en (toekomstige) ontwikkelingen binnen de veehouderijsectoren die een relatie (kunnen) hebben met brandveiligheid van veestallen voor dieren.

\subsection{Verwacht vervangingsritme nieuwbouw/renovatie}

De nieuwe eisen in het Bouwbesluit zijn alleen van toepassing op stallen die na de ingangsdatum (1-42014) worden vergund. Dit betekent dat bestaande stallen pas aan de nieuwe eisen moeten voldoen als ze op enig moment worden vervangen door nieuwbouw of (grondig) worden gerenoveerd. Technisch gezien gaan stallen vrij lang mee. Voor de ruwbouw (fundering, muren en dak) geldt de langste afschrijvingstermijn, de stalinrichting (tussenmuren, hokafscheidingen en al het ijzerwerk kent een kortere afschrijvingstermijn) en de technische installaties (klimaatregelapparatuur, voerautomatisering, verwarming, verlichting en melkwinningsapparatuur) kennen in de regel de kortste afschrijvingstermijn. De afschrijftermijnen die in de praktijk worden gehanteerd zijn enigszins verschillend tussen sectoren. Onderstaande tabel geeft hiervan een overzicht.

Tabel 7.1 Gangbare afschrijvingstermijnen voor veestallen (bron: KWIN 2016/2017)

\begin{tabular}{|c|c|c|c|c|c|c|c|c|}
\hline & Rundvee & & Varkens & & Pluimvee & & Vleeskalveren & \\
\hline & & & & & & & Onderdelen & \\
\hline Ruwbouw & $\begin{array}{l}\text { Grondwerk, putten, } \\
\text { buitenmuren, } \\
\text { spanten, gordingen, } \\
\text { dakbedekking, } \\
\text { Erfverharding, } \\
\text { Sleufsilo's }\end{array}$ & $20 \mathrm{jr}$ & $\begin{array}{c}\text { Grondwerk, putten, } \\
\text { buitenmuren, spanten, } \\
\text { gordingen, } \\
\text { dakbedekking, } \\
\text { erfverharding }\end{array}$ & $40 \mathrm{jr}$ & $\begin{array}{l}\text { Jrondwerk, stalvloer, } \\
\text { buitenmuren, } \\
\text { spanten, gordingen, } \\
\text { dakbedekking, } \\
\text { erfverharding }\end{array}$ & $25 \mathrm{jr}$ & $\begin{array}{l}\text { Grondwerk, putten, } \\
\text { buitenmuren, } \\
\text { spanten, gordingen, } \\
\text { dakbedekking, } \\
\text { erfverharding }\end{array}$ & $20 \mathrm{jr}$ \\
\hline Stalinrichting & $\begin{array}{l}\text { Betonvloeren, } \\
\text { ligboxen } \\
\text { betonroosters, } \\
\text { elektrische } \\
\text { installatie, deuren, } \\
\text { open nok, voerhek, } \\
\text { boxafscheidingen, } \\
\text { krachtvoersilo's }\end{array}$ & $20 \mathrm{jr}$ & $\begin{array}{l}\text { Betonvloeren, } \\
\text { dakisolatie, vaste } \\
\text { luchtverdeelsystemen, } \\
\text { rioleringssystemen, } \\
\text { elektrische installatie, } \\
\text { deuren, binnenmuren, } \\
\text { stukadoorswerk, } \\
\text { ventilatiekokers, silo's }\end{array}$ & $20 \mathrm{jr}$ & $\begin{array}{c}\text { dakisolatie, } \\
\text { lektrische installatie, } \\
\text { sierverzamelsysteem, } \\
\text { drinkwatersysteem, } \\
\text { luchtbehandeling, } \\
\text { volières } \\
\text { ventilatiekokers, } \\
\text { noodstroom- } \\
\text { voorziening, silo,s }\end{array}$ & $\underset{j r}{12 / 15}$ & $\begin{array}{l}\text { Betonvloeren, } \\
\text { betonroosters, } \\
\text { dakisolatie, } \\
\text { elektrische } \\
\text { installatie, deuren, } \\
\text { binnenmuren, } \\
\text { stukadoorswerk, } \\
\text { ventilatiekokers, } \\
\text { silo's }\end{array}$ & $20 \mathrm{jr}$ \\
\hline $\begin{array}{l}\text { Technische } \\
\text { installaties }\end{array}$ & $\begin{array}{c}\text { Regelbare gordijnen, } \\
\text { drinkwaterinstallatie, } \\
\text { krachtvoersysteem, } \\
\text { melk- en } \\
\text { koelapparatuur } \\
\text { Mestschuiven/- } \\
\text { robotjes, } \\
\text { box- en vloermatten }\end{array}$ & $20 \mathrm{jr}$ & $\begin{array}{c}\text { Vloerafwerking, } \\
\text { roosters } \\
\text { hokinrichting, } \\
\text { ventilatiesysteem, } \\
\text { verwarmingsinstallatie } \\
\text { drinkwaterinstallatie, } \\
\text { voerinstallatie } \\
\text { luchtwassers } \\
\text { kadaverkoeling }\end{array}$ & $10 \mathrm{jr}$ & $\begin{array}{l}\text { Ventilatiesysteem, } \\
\text { verwarming, } \\
\text { Mest- en eierbanden, } \\
\text { alarminstallatie, } \\
\text { luchtwassers, } \\
\text { regelcomputer, } \\
\text { kadaverkoeling }\end{array}$ & $\begin{array}{c}7 / 10 \\
j r\end{array}$ & $\begin{array}{c}\text { Houten roosters, } \\
\text { roostermatten, } \\
\text { hokinrichting, } \\
\text { ventilatiesysteem, } \\
\text { verwarmingsinstalla } \\
\text { tie } \\
\text { drinkwaterinstallatie } \\
\text {, voerinstallatie, } \\
\text { luchtwassers }\end{array}$ & $10 \mathrm{jr}$ \\
\hline
\end{tabular}

KWIN hanteert geen uniforme wijze van afschrijven over sectoren. [Dit heeft een historische achtergrond, toen afschrijvingstermijnen nog sectoraal door landbouwvoorlichting, LEI en Praktijkonderzoek werden bepaald.] Per saldo komt het er volgens KWIN op neer dat de investering in een stal in Nederland gemiddeld in 18 - 20 jaar wordt afgeschreven. In tabel 7.1 staat aangegeven welke afschrijvingstermijnen KWIN per sector voor de belangrijkste stalonderdelen hanteert. Echter, voor de varkenshouderij is indertijd een zeer gedetailleerde wijze van afschrijven ontwikkeld, die de technische en economische levensduur goed benadert. Er zijn geen argumenten waarom deze werkwijze niet bij de andere sectoren kan worden toegepast. De ruwbouw van een gangbare melkveestal gaat immers zeker 40 jaar mee en er is vaak geen noodzaak deze eerder af te breken. Bij de varkens- en pluimveehouderij komt het wel voor dat een stal wordt afgebroken voordat deze is afgeschreven. Een ondoelmatige maatvoering of weinig flexibele indeling is dan veelal de oorzaak dat zo'n stal niet meer past in de opschaling van dieraantallen op deze bedrijven. Bovendien nemen die kleine stallen vaak veel bouwblokruimte in beslag. Bij de verdere discussie over afschrijvingstermijnen hanteren we het afschrijvingsmodel voor de varkenshouderij. 
Als het gaat om de implementatie van het Bouwbesluit 2014, dan komt dit aan de orde bij de vergunningverlening van een nieuwe stal en zal het ca. 40 jaar duren voordat de eisen uit het nieuwe bouwbesluit breed zijn geïmplementeerd.

Stalrenovaties, zoals het vervangen van stalinrichting en technische installaties, zijn vaak niet zichtbaar voor de gemeente. Hiervoor is in de regel geen vergunning vereist en als dit wel het geval is, is het een vergunning in het kader van de Wet Milieubeheer en niet zozeer in het kader van de bouwregelgeving.

In onderstaande tabel staat een overzicht van het totaal aantal stallen per veehouderijsector en het aantal nieuw gebouwde stallen in de periode 2009-2013.

Tabel 7.2 Overzicht van aantal (nieuwgebouwde) stallen en dierplaatsen in de veehouderijsectoren (bron: Landbouwtelling 2014)

\begin{tabular}{|c|c|c|c|c|c|c|c|c|}
\hline & \multicolumn{2}{|c|}{ Rundvee } & \multicolumn{2}{|c|}{$\begin{array}{l}\text { Waarvan Melkvee als } \\
\text { hoofdactiviteit }\end{array}$} & \multicolumn{2}{|c|}{ Varkens } & \multicolumn{2}{|c|}{ Pluimvee } \\
\hline & stallen & dierplaatsen & stallen & dier-plaatsen & stallen & dier-plaatsen & stallen & dierplaatsen \\
\hline Totaal vóór 2009 & 54,725 & & 34,427 & & 13506 & & 4,769 & \\
\hline Totaal 2009 & 1,342 & 158,049 & 1,032 & 117,439 & 291 & 445,659 & 164 & $4,040,308$ \\
\hline Totaal 2010 & 1,273 & 159,516 & 971 & 109,340 & 327 & 497,479 & 229 & $7,054,854$ \\
\hline Totaal 2011 & 1,175 & 161,274 & 919 & 109,840 & 312 & 454,055 & 211 & $6,649,055$ \\
\hline Totaal 2012 & 1,231 & 201,217 & 934 & 106,695 & 364 & 511,868 & 284 & $8,824,338$ \\
\hline Totaal 2013 & 1,371 & 161,242 & 1,051 & 116,983 & 341 & 464,024 & 165 & $4,758,861$ \\
\hline $\begin{array}{l}\text { Totaal rapport } \\
\text { monitoring } 2014\end{array}$ & 53,656 & $3,282,000$ & niet bekend & niet bekend & 18,756 & $12,119,000$ & 4,691 & $121,992,000$ \\
\hline $\begin{array}{l}\text { Aantal nieuwe } \\
\text { stallen per jaar }\end{array}$ & 1,065 & 140,216 & 818 & 93,383 & 273 & 395,514 & 176 & $5,221,236$ \\
\hline Dierplaatsen/stal & & 132 & & 114 & & 1,451 & & 29,751 \\
\hline
\end{tabular}

In de periode 2009-2013 zijn er gemiddeld per jaar ruim 800 nieuwe melkveestallen gebouwd met gemiddeld 114 dierplaatsen, ruim 270 varkensstallen met gemiddeld ruim 1400 dierplaatsen, en circa 180 pluimveestallen met gemiddeld een kleine 30.000 dierplaatsen. Als we het aantal stallen in de monitoring van 2014 relateren aan het aantal bedrijven in 2014 zoals weergegeven in tabel 4.2, dan bestaan rundveebedrijven uit gemiddeld 1.8 stallen, varkensbedrijven uit gemiddeld 3.7 stallen en pluimveebedrijven uit gemiddeld 2.2 stallen.

\subsection{Ontwikkelingen per sector}

Breed in de veehouderij zijn een aantal ontwikkelingen waar te nemen die gelden voor meerdere sectoren, zoals schaalvergroting, mestbewerking en biogas, toepassen van luchtreinigingstechnieken. In tabel 7.3 is van een aantal van deze ontwikkelingen voor de diverse sectoren weergegeven hoe ze worden ingeschat. 
Tabel 7.3 (Toekomstige) ontwikkelingen in de verschillende sectoren

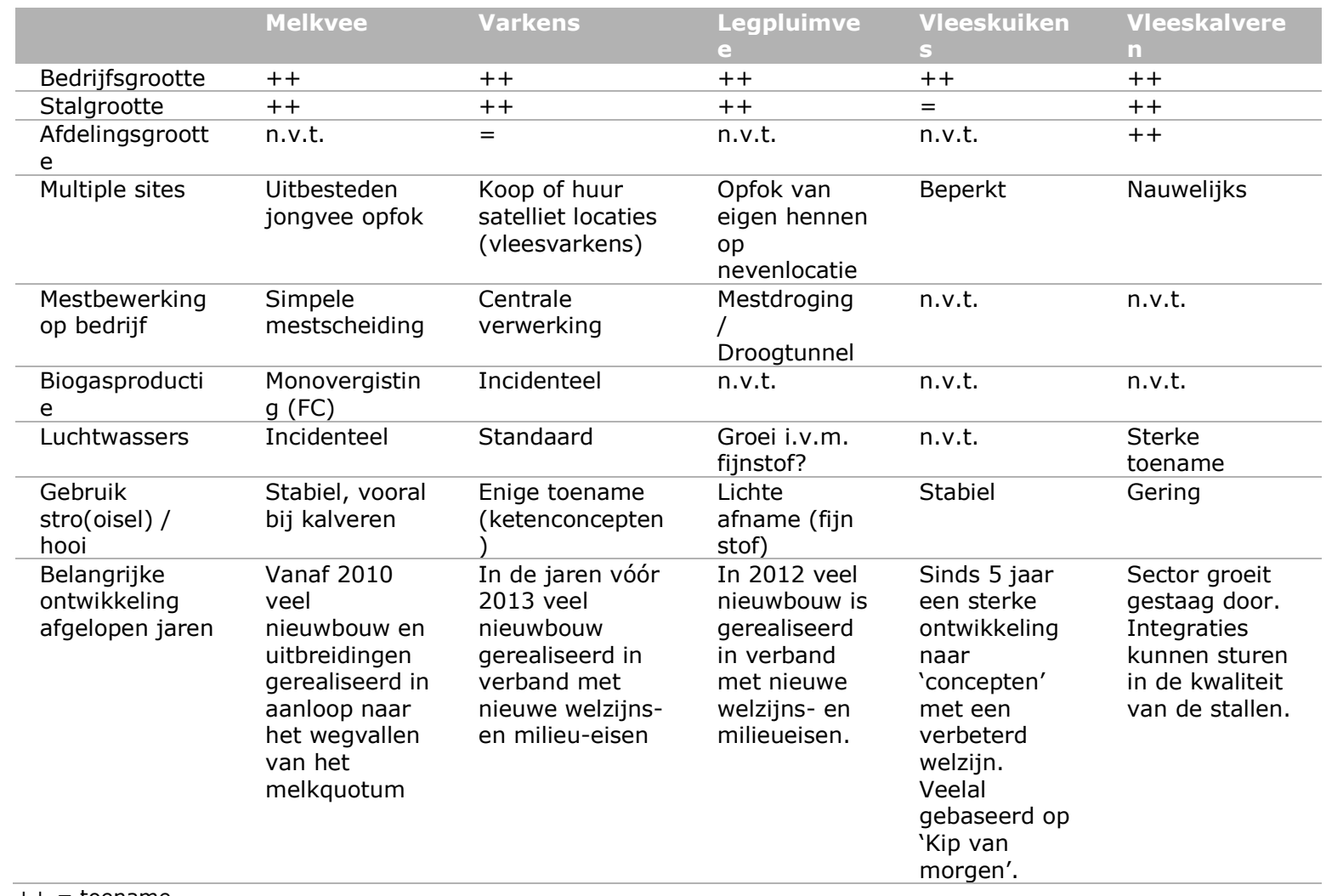

++ toename

$==$ blijft gelijk

De verdergaande schaalvergroting in de veehouderij zal een uitfasering tot gevolg hebben van met name kleinere/oudere stallen. Dit proces wordt mogelijk versneld door diverse wetten en regelingen zoals:

- Verbod op asbesthoudende daken per 2024. Dit is van toepassing op alle (stal)daken die voorzien zijn van vezelcement golfplaten van voor 1994.

- 'Stoppersregeling ammoniak'; dit betreft bedrijven die niet per 1 januari 2013 wilden of konden investeren in ammoniakreducerende technieken, om te kunnen voldoen aan de maximale emissieeis van het toenmalige Besluit huisvesting. Het betreft vooral varkens- en in mindere mate pluimveebedrijven. Deze mochten op bedrijfsniveau eenvoudige maatregelen nemen (bv minder dieren houden of voedingsmaatregelen), mits ze uiteindelijk stoppen per 1 januari 2020.

- 'Fosfaatreductieplan \& Stoppersregeling '; De onlangs afgekondigde stoppersregeling voor melkleverende bedrijven zal tot een versnelde sanering van de melkveebedrijven leiden. Aan de eerste trance nemen ca. 500 bedrijven deel.

- "Fosfaatrechten melkvee": De aangekondigde introductie van fosfaatrechten voor melkvee in combinatie met afroming leidt al direct tot een vermindering van de melkveestapel. Afhankelijk van de uiteindelijke invulling van de fosfaatrechten, kan dit ook grote gevolgen hebben voor de zoogkoeienhouderij en roodvleesproductie.

In bijlage 5 is een beeld geschetst van sectorspecifieke ontwikkelingen met een mogelijke relatie naar brandveiligheid voor de melkvee-, vleeskalver-, varkens-, leghennen- en vleeskuikenhouderij. 


\subsection{Ontwikkelingen in kwaliteitssystemen}

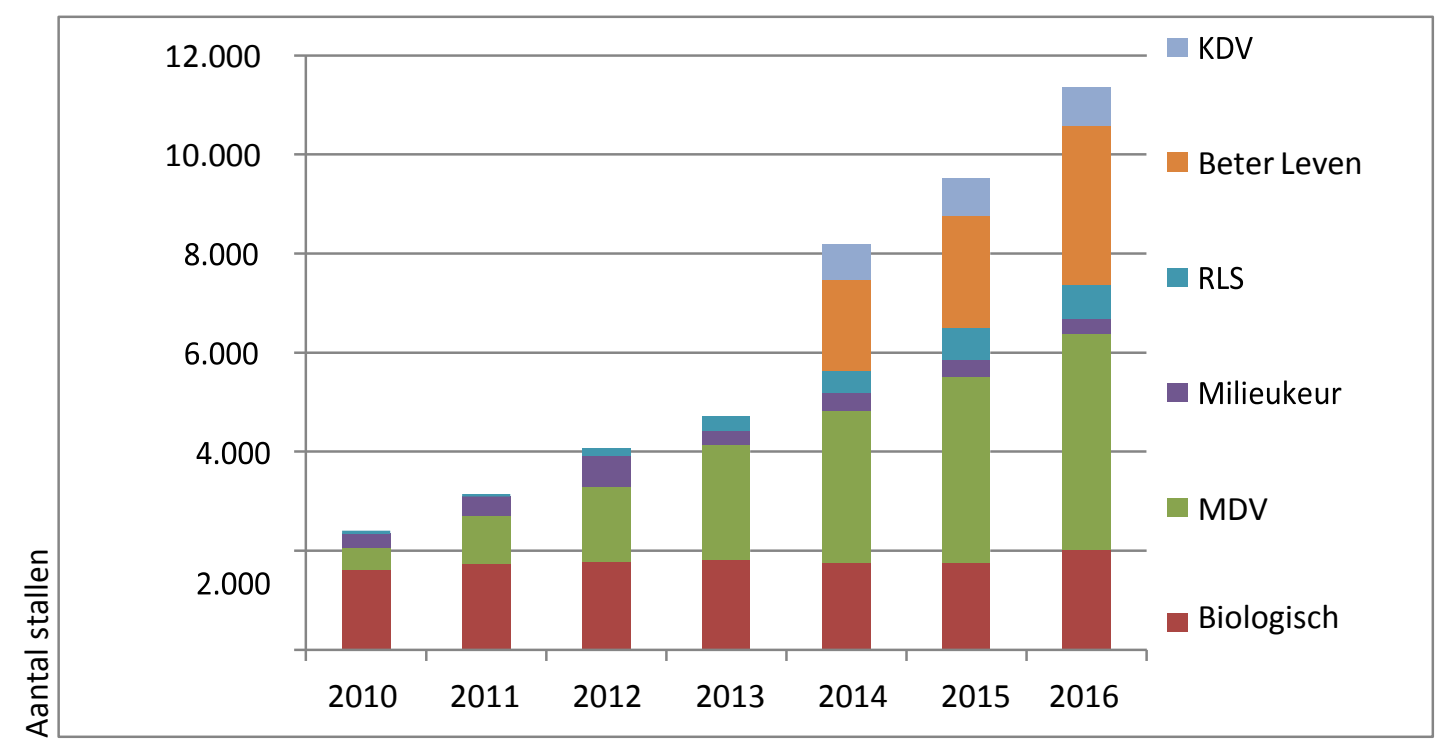

Figuur 7.1 Ontwikkeling van de verschillende keurmerken voor integraal duurzame veehouderij stallen (bron: Van der Peet et al., januari 2016))

We zien in de afgelopen jaren een toename in de bouw van stallen met een keurmerk voor integraal duurzame veehouderij. Daarbij is vooral het aantal stallen met een MDV-certificaat (Maatlat Duurzame Veehouderij), een Beter Leven certificaat of een KDV-certificaat (Keten Duurzaam Varkensvlees) toegenomen (figuur 7.1).

\section{Beter Leven en brandveiligheid}

Het Beter Leven-keurmerk van de Dierenbescherming vereist sinds 2016 minimaal eens in de vijf jaar een Agro Elektra Inspectie bij leghennen (1,2,3 sterren), vleeskuikens $(1,2,3$ sterren), vleeskalveren ( 1 ster rosé), runderen (1, 2 sterren), varkens (1, 2, 3 sterren) en kalkoenen (1, 2 sterren). Tevens vraagt men de aanwezigheid van een objectinformatiekaart van de locatie bij Beter Leven Varkens (1 ster).

\section{Maatlat Duurzame Veehouderij en brandveiligheid}

Sinds 2014 is Brandveiligheid een verplichte module binnen de Maatlat Duurzame Veehouderij (MDV). De Stichting Milieukeur (SMK) is beheerder van het systeem. SMK heeft geen overzicht van welke brandveiligheidsmaatregelen per jaar zijn gerealiseerd. $\mathrm{Er}$ is wel een overzicht van de ontwikkeling van het totaal behaalde aantal punten voor brandveiligheid ten opzichte van het MDV-ambitieniveau, hetgeen een indicatie geeft hoeveel maatregelen/investeringen veehouders nemen op brandveiligheidsgebied. De afgelopen 2 jaar is het ambitieniveau verhoogd van 11 punten in 2014 naar 16 punten voor melkvee, 19 punten voor pluimvee en 20 punten voor varkens.

$\mathrm{Na}$ het eerste jaar is door SMK geëvalueerd welke maatregelen er veel/weinig worden genomen. Uit deze evaluatie bleek dat er 5 brandveiligheidsmaatregelen zijn die favoriet zijn bij alle deelnemers van alle diercategorieën, dus vaak worden uitgevoerd. Dit betreft:

- Beveiliging tegen oververhitting van de elektromotoren in het dierverblijf (2 punten)

- Opslag van brandbare voer- en strooiselmaterialen buiten het brandcompartiment met de dierverblijven ( 2 punten)

- 'Open' uitvoering van kabelgoten (2 punten)

- Minimaal een goedgekeurde brandblusser per $1000 \mathrm{~m}^{2}$ staloppervlak (2 punten)

- Vast noodstroomaggregaat in aparte afgesloten ruimte (2 punten)

Met deze 5 favoriete maatregelen behaalden de meeste deelnemers 10 van de in 2014 benodigde 11 punten. Het laatste benodigde punt voor de brandveiligheidsmaatlat werd op zeer uiteenlopende wijze behaald. 
Alle melkveehouders uit de steekproef behaalden naast deze favoriete maatregelen altijd punten voor natuurlijk geventileerde dierverblijven en voor minimaal 2 toegangsdeuren in het dierverblijf.

In de eerste helft van 2014 zijn 7 (deel)maatregelen door niemand gekozen. Dit lijken maatregelen te zijn die een relatief grotere investering vragen, zoals de installatie van een sprinklerinstallatie, hoogste brandklasse van hokinrichtingsmaterialen en brandmelders op risicoplaatsen in stal. De brandveiligheidsintroductie in 2014 betekent dat er ruwweg vanaf 2015 daadwerkelijk MDV-stallen in gebruik zijn genomen die brandveiligheidsinvesteringen hebben gedaan. Er zijn in de periode 20152016 geen stalbranden geweest in MDV-gecertificeerde stallen (alle incidenten betrof stallen van vóór 2014).

Van alle stallen die in Nederland gebouwd worden (zie tabel 7.2), is de laatste jaren 30-40\% MDVgecertificeerd. Sinds 2012 is het aandeel flink toegenomen. Van de sinds 2013 gebouwde varkensstallen is ca. $90 \%$ MDV-gecertificeerd, van pluimveestallen $>80 \%$ en van melkveestallen ca. $25 \%$.

\section{IKB en brandveiligheid}

De beheerders van de sectorale (IKB-)kwaliteitssystemen zijn door de initiatiefnemers van het Actieplan Stalbranden gevraagd om een AgroElektra inspectie op te nemen in hun voorwaarden. De komende periode zal hierover nadere besluitvorming plaatsvinden. IKB Kip en IKB Ei hebben inmiddels de intentie uitgesproken om aan het verzoek gehoor te geven. IKB Varken heeft aangegeven voorlopig te volstaan met voorlichting over de AgroElektra inspectie. Andere kwaliteitssystemen hebben het in overweging of nemen het niet op. 


\section{$8 \quad$ Analyse van de bevindingen}

\section{Bewustzijn brandveiligheid}

De kans op stalbrand is relatief klein ( 0.5 tot 2.3 stalbranden per 1000 bedrijven per jaar). Voor alle veehouders geldt dat keuzes in bedrijfsvoering en bedrijfsontwikkeling veelal worden beïnvloed door de wens tot kostenbesparing. De hoeveelheid regels waaraan ondernemers moeten voldoen en de vaak slechte verdiensten in de afgelopen jaren beperken de aandacht voor brandveiligheid. Veel veehouders zijn zich niet bewust van het risico van gevolgschade bij stalbrand, waardoor de continuïteit van het bedrijf in gevaar zou kunnen komen.

Uit de interviews en de respons op de internetenquête leiden we af dat het bewustzijn van veehouders met betrekking tot brandveiligheid is toegenomen in de looptijd van het actieplan, maar niet onder alle typen veehouders. Een onderscheid in drie typen veehouders is hierbij relevant: de schaalvergroter, de verbreder en de uitfaseerder (voor typering, zie kader 8.1). Met name onder schaalvergroters is het bewustzijn ten aanzien van brandveiligheid vergroot. Bij de andere typen veehouders, de verbreder en de uitfaseerder, is het bewustzijn met betrekking tot brandveiligheid naar verwachting niet veranderd in de afgelopen jaren.

\section{Kader 8.1 Typering veehouders in relatie met bewustzijn brandveiligheid}

Schaalvergroters typeren we als relatief jonge, grootschalige ondernemers, bezig met bedrijfsontwikkeling en vaak manager van meerdere vestigingen. Het ontbreekt vaak aan permanent toezicht op nevenvestigingen. Deze ondernemer is zich meer dan de andere typen veehouders bewust van het belang van brandveilige stallen en brandveilig werken, vanwege de economische belangen, om continuïteit te waarborgen in geval van brand (verzekerbaarheid). Brandveiligheid voor dieren lijkt voor de schaalvergroter op zichzelf geen kwestie, het lift wel mee op de aandacht voor brandveiligheid van het bedrijf.

De verbreder kan worden getypeerd als een bewust kleinschalige ondernemer, vaak biologisch of producerend binnen andere welzijnsconcepten, veel met uitloopsystemen, multifunctionele landbouw, zorgboerderij e.d. De verbreder woont bij het bedrijf en zal veel (in potentie brandgevaarlijke) werkzaamheden zelf uitvoeren. De productie binnen welzijnsconcepten brengt met zich mee dat er vaker sprake is van aanwezigheid en toepassing van brandbare materialen zoals stro en hooi dan in reguliere houderijsystemen. De verbreder is naar verwachting wel aanspreekbaar op aspecten van brandveiligheid: in algemene zin is deze ondernemer al meer bezig met veiligheid van mens en dier.

De uitfaseerder is een ondernemer zonder toekomstperspectief, met verouderde stallen, die binnen afzienbare tijd zal stoppen met de bedrijfsvoering en geen substantiële investeringen meer doet en vaak alleen het hoogst noodzakelijke onderhoud. De uitfaseerder is niet specifiek gericht op brandveiligheid en er waarschijnlijk ook niet op aanspreekbaar. We gaan er vanuit dat deze groep ondernemers in de afgelopen jaren minder is bereikt en in de toekomst ook minder bereikt zal worden met voorlichting over brandveiligheid.

Met de vorming van de veiligheidsregio's is de brandweer volgens eigen zeggen op (veel) grotere afstand van de (grootschalige) veehouder/vergunningaanvrager komen te staan. Voorheen ging de initiatiefnemer vaak met brandweer, gemeente, bouwadviseurs en eventueel anderen gezamenlijk om de tafel om het ontwerp vanuit verschillende perspectieven te bespreken. De vraag om advies van de brandweer is nu meer geformaliseerd, en loopt indirect via de gemeente. Vaak heeft de brandweer alleen contact met de bouwadviseur als tussenpersoon. Direct contact van brandweer met vergunningaanvrager kan het brandveilig denken bevorderen. In de praktijk blijken veehouders dan ook meer open te staan voor het nemen van brandveiligheidsmaatregelen. Bouwen wordt steeds meer onder regie van de veehouder zelf, zonder betrokkenheid van een extern bureau, uitgevoerd.

Aannemers lijken nog steeds de zwakke schakel waar het gaat om de planconforme uitvoering van het bouwplan. Aangegeven wordt dat aannemers uit praktische of financiële overwegingen bij de aanbesteding en gaandeweg de bouw regelmatig van het plan afwijken. Die mogelijkheid wordt versterkt als voldoende toezicht op naleving van de regels ontbreekt. Veranderingen in het bouwplan zijn bij oplevering bovendien niet altijd zichtbaar.

\section{Brandveilig werken}

Uit de interviews komt naar voren dat brandgevaarlijke werkzaamheden nog steeds belangrijke veroorzakers van stalbrand zijn. Dit wordt ondersteund door het overzicht van oorzaken van bekende van stalbranden in de periode 2014-2016 (bron: Brandweer Nederland): van circa $14 \%$ van de stalbranden in deze periode is bekend dat de oorzaak heeft gelegen in werkzaamheden. De gemiddelde ondernemer voert herstelwerkzaamheden zoals lassen en slijpen zelf uit. Het zit soms in kleine dingen (bouwlamp bij werkzaamheden die direct op de isolatie wordt gezet). Grootschalige 
ondernemers schakelen doorgaans professionele bedrijven in, vaak ook op aangeven van de verzekeraar. Maar ook bij uitvoering door professionele bedrijven gaat het af en toe mis (installateurs, dakdekkers), zoals blijkt uit stalbrandincidenten in de periode 2012-2016.

De enquête onder veehouders heeft extra inzicht gegeven in de huidige situatie met betrekking tot brandveilig werken. Daaruit blijkt dat werk aan elektrische systemen in zo'n $60 \%$ van de gevallen aan professionals wordt uitbesteed. Las- en slijpwerkzaamheden daarentegen gebeuren, zeker in de intensieve sectoren, vaak in eigen beheer. Daarbij worden voorzorgsmaatregelen genomen (brandblusser paraat en dergelijke), maar brandveilig afdekken van de mestput is als preventieve maatregel nog geen gemeengoed (gebeurt op ca. $40 \%$ van de bedrijven). De enquête bevestigt het beeld uit de interviews dat op veel intensieve bedrijven recentelijk een elektrakeuring is uitgevoerd. De melkveehouderij blijft hierin nog enigszins achter, maar zal de komende jaren mogelijk een inhaalslag maken op aangeven van verzekeraars. Ook is een belangrijk deel van de elektromotoren in dierverblijven inmiddels beveiligd tegen oververhitting. Op een deel van de bedrijven (alle sectoren) worden nog open-vuur heaters toegepast. Een klein deel van de melkveehouders stalt nog steeds machines met gevaar op zelfontbranding in de stal. Aanwezigheid van een objectinformatiekaart voor de brandweer is op veel bedrijven nog niet gebruikelijk (20\% van de respondenten, met name intensieve veehouders) beschikken er over.

In praktijknetwerken zijn een aantal praktische oplossingen naar voren zijn gekomen, zoals brandgevaarlijke werkzaamheden waar mogelijk in andere ruimten uitvoeren, stofvrij houden van open kabelgoten en infraroodcamera's waarmee hittelekken in elektrische systemen en bedrading kunnen worden opgespoord. In enkele interviews is hieraan gerefereerd: dergelijke praktische oplossingen, relatief eenvoudig inpasbaar in de bestaande bedrijfsvoering, worden als waardevol gezien.

\section{Ontwikkelingen in kans op brand met dierlijke slachtoffers}

Op basis van de resultaten van de interviews met gemeenten en brandweer, bouwadviesbureaus en verzekeraars is een kwalitatieve inschatting gemaakt van veranderingen sinds de start van het Actieplan in de kans op ontstaan van brand, snelle detectie, branduitbreiding, blussen en evacuatie van dieren, en van de daaruit voortvloeiende overall kans op brand met dierlijke slachtoffers (zie tabel 8.1, conform de structuur van het beoordelingskader in fig.2.1).

De overall kans op brand met dierlijke slachtoffers is bij nieuwbouw na 1-4-2014 in gunstige zin is veranderd. Dit hangt samen met de nieuwe voorschriften in het Bouwbesluit over compartimentering van technische ruimten en de hogere brandklasse van constructie/-isolatiematerialen. Het hangt ook samen met keuringseisen die verzekeraars en/of gemeenten stellen aan elektrische apparaten bij oplevering van de nieuwbouw en de eisen van verzekeraars voor periodieke keuring na ingebruikname ervan.

De beperkingen die aan de omvang van bouwblokken worden gesteld zorgen er, in combinatie met de toenemende schaalvergroting, bij nieuwbouw voor dat nieuwe stallen aan bestaande stallen worden gebouwd of er dicht bij worden geplaatst. Dit vormt bij brand een extra risico op brandoverslag tussen brandcompartimenten en/of op dierlijke slachtoffers in naastgelegen compartimenten door binnenkomen van hete en/of giftige lucht.

Er wordt bij nieuwbouw enige toename gezien in branddetectie in de technische ruimte. Ook lijkt men bij nieuwbouw alerter te zijn op de aanwezigheid van handblusmiddelen.

Voor de melkveehouderij wordt ingeschat dat de evacuatiekansen van dieren bij brand verminderen indien bij nieuwbouw een extra spant aan de bestaande stal wordt gebouwd.

Voor bestaande stallen in de verschillende sectoren schatten we in dat de brandveiligheid in de afgelopen jaren in geringe mate is verbeterd. Dat hangt uitsluitend samen met de gunstige ontwikkeling die op gang is gekomen in periodieke keuring van elektrische apparaten in de verschillende sectoren, vanwege eisen in het kader van de brandverzekering. Het is belangrijk dat een dergelijke periodieke keuring gemeengoed wordt binnen de verschillende sectoren, zowel voor bestaande stallen als na oplevering van nieuwgebouwde stallen. 
Tabel 8.1 Inschatting veranderingen in brandveilige stallen t.o.v. start Actieplan 2012 [NB: + = in gunstige zin veranderd; - = in ongunstige zin veranderd; $\approx$ = niet wezenlijk veranderd]

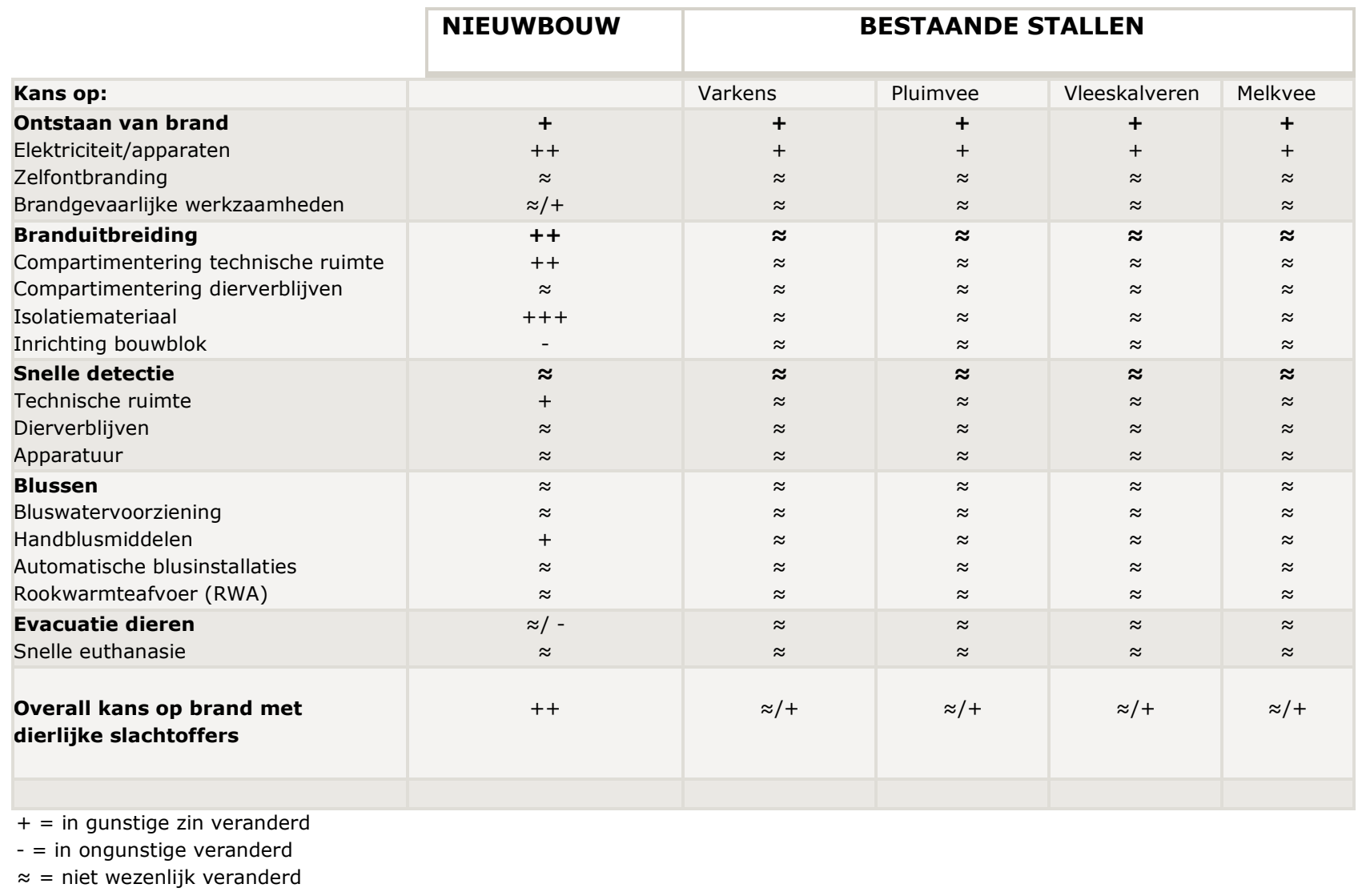

\section{Kennis over wet- en regelgeving}

Binnen het Actieplan Stalbranden is via meerdere kanalen gecommuniceerd met als doel om de kennis over wet- en regelgeving bij stallenbouwer, gemeente en veehouder te vergroten.

In de praktijk blijkt op een aantal terreinen nog onduidelijkheid te bestaan over de juiste toepassing van de bouwregelgeving bij zowel nieuw te bouwen stallen als bestaande stallen (zie bijlage 6). Deze onduidelijkheden leiden soms tot onjuiste toepassingen en daarmee tot een lager niveau van brandveiligheid dan de wetgever heeft beoogd. Deze onduidelijkheden komen met name tot uiting bij het toepassen van gelijkwaardigheid en bij het uitbreiden van bestaande stallen.

Het Bouwbesluit geeft brandveiligheidsregels voor brandcompartimenten waarin dieren verblijven tot een maximale omvang van $2.500 \mathrm{~m}^{2}$. die niet aan de regelgeving voldoen maar op een andere manier aantonen gelijkwaardig te zijn in brandveiligheid. Door sommige gemeenten worden vergunningaanvragen voor brandcompartimenten groter dan $2.500 \mathrm{~m}^{2}$ in behandeling genomen, waarbij gelijkwaardigheid op basis van NEN-normen 6060 en 6079 door de vergunningaanvrager is aangetoond. Deze NEN-normen waren echter niet bedoeld voor brandcompartimenten $>2.500 \mathrm{~m}^{2}$. Eind 2017 verschijnen bijlagen van de NEN-normen 6060 en 6079, die wel van toepassing zijn voor veestallen groter dan $2500 \mathrm{~m}^{2}$.

Geconstateerd kan worden dat de kennis over interpretatie van bestaande wet- en regelgeving over het toepassen van gelijkwaardigheid bij grotere brandcompartimenten bij gemeenten uiteenloopt, en dat dit naar verwachting ook een spin-off heeft naar stallenbouwers en veehouders binnen de betreffende gemeenten.

Hetzelfde lijkt te gelden voor interpretatie van de eisen bij uitbreiding van bestaande stallen. Meerdere geïnterviewden waren van mening dat bij uitbreiding alleen hoeft te worden voldaan aan de normen die betrekking hebben op het bestaande stalgedeelte. In werkelijkheid geldt de eis van minimaal brandklasse $\mathrm{B}$ voor bouwmaterialen ook voor de uitbreiding van een bestaand dierverblijf (zie bijlage 6). Brede voorlichting over de interpretatie van de regelgeving op dit punt, bij voorkeur geïllustreerd met praktijkvoorbeelden, is van belang. 


\section{Handvatten voor beoordeling van gelijkwaardigheid}

Het onderzoeksteam heeft de concept-normen NEN 6060 en 6079 ingezien. Of deze normen een goed handvat bieden om de gelijkwaardigheid in brandveiligheid van grote brandcompartimenten in voldoende mate te waarborgen, is nog niet in te schatten, omdat bijvoorbeeld de achtergronden van gebruikte weegfactoren en verstekwaarden niet bekend zijn.

Daarnaast wil het onderzoeksteam een belangrijke zorg uiten. Uit de geschetste (toekomstige) ontwikkelingen binnen de veehouderijsectoren wordt duidelijk dat schaalvergroting in de afgelopen jaren een belangrijke vlucht heeft genomen en dat deze ontwikkeling zich in de komende jaren naar verwachting onverminderd zal voortzetten. Daar komt bij dat inzet van de brandweer bij stalbrand in principe gericht is op het gecontroleerd laten uitbranden en het voorkómen van overslag naar belendingen; in de intensieve veehouderij zijn er weinig mogelijkheden voor het redden van dieren. Beoordeling van gelijkwaardigheid op basis van de kans op het ontstaan en uitbreiding van stalbrand doet slechts deels recht aan het bevorderen of gelijk houden van de brandveiligheid voor dieren in grotere brandcompartimenten. Risico = kans $\mathrm{x}$ effect. De kans op stalbrand is op dit moment al relatief klein en zal mogelijk verder kunnen afnemen. Het aantal dieren dat per incident omkomt, zal bij voortgaande schaalvergroting en 'niet-begrensde' omvang van brandcompartimenten waarin zich de dierverblijven bevinden sterk kunnen toenemen, ook al is de kans op ontstaan en uitbreiden van stalbrand aantoonbaar 'gelijkwaardig' aan de kans bij kleinere compartimenten. Dit wordt nog versterkt door brandcompartimenten met dierverblijven die door begrenzing van het bouwblok bij schaalvergroting steeds dichter op elkaar zullen worden geplaatst. Dit pleit voor het stellen van een bovengrens aan de omvang van brandcompartimenten met dierverblijven, onderbouwd via een zo objectief mogelijke inschatting van risico = kans $x$ effect. Het is nog niet bekend of de bijlagen van de NEN-normen 6060 en 6079, die naar verwachting eind 2017 verschijnen, dit probleem zullen oplossen.

\section{Handhaven op brandveiligheid}

De werkgroep Actieplan geeft in haar voortgangrapportage aan dat het niet mogelijk is om brandveiligheid onderdeel te laten uitmaken van de integrale handhavingsstrategie van gemeenten. Er liggen andere prioriteiten in het toezicht. In plaats daarvan worden omgevingsdiensten gevraagd om tijdens reguliere milieu-inspecties ook te letten op brandveiligheid. Ook uit onze interviews komt naar voren dat milieu-inspecties een goed middel kunnen zijn om ondernemers te wijzen op risico's met betrekking tot brandveiligheid. Grote bedrijven worden door omgevingsdiensten met een frequentie van ca. 1 keer per 5 jaar bezocht. Opvolging van adviezen zal deels vrijblijvend zijn (indien de ondernemer geen vergunning nodig heeft voor opslag brandgevaarlijke stoffen e.d.), maar in elk geval bewustwording kunnen ondersteunen.

\section{Bouwplantoets van publiek naar privaat}

Met de inwerkingtreding van de Wet Kwaliteitsborging voor het Bouwen verschuift met ingang van 2018 de preventieve toets op de plannen en het toezicht op uitvoering van nieuwbouw en verbouw van de gemeente naar een private kwaliteitsborger. Uitzondering: indien gebruik wordt gemaakt van een gelijkwaardige oplossing en/of bij bouwwerken die uit meer dan twee bouwlagen bestaan blijft de toets vooralsnog plaatsvinden door de gemeente.

Een ondervraagde gemeente en brandweer maken zich zorgen over de privatisering van de preventieve bouwplantoets en controles bij oplevering. Ze zijn bang dat de kwaliteit ermee in het geding komt.

Sinds 2014 is er al een gecertificeerde bouwplantoets beschikbaar (Beoordelingsrichtlijn voor Bouwplantoetsingen aan het Bouwbesluit (BRL 5019)), en een beoordelingsrichtlijn voor gecertificeerd toezicht (BRL 5006). Diverse gemeenten (26 in 2016) passen bij toepassing van BRL5019 (of in sommige gevallen een ander instrument) al korting toe op de leges voor een omgevingsvergunning voor het bouwen. (http://www.stichtingibk.nl/2016/01/08/legeskorting-met-privatebouwplantoetsing-in-2016/). Deze gemeenten doen vooruitlopend op de inwerkingtreding van Wet Kwaliteitsborging voor het Bouwen al ervaring op met een geprivatiseerde bouwplantoets en toezicht tijdens de bouw. Het is niet bekend in hoeverre dit ook al bij stallenbouw wordt toegepast. Private toets en toezicht op de bouw door de bouwspecialisten zelf zal naar de mening van de rijksoverheid kwaliteitsvoordelen hebben. Het is daarbij een voorwaarde dat het toezicht op toezicht 
(door een onafhankelijke toezichthouder) en verantwoordelijkheden/aansprakelijkheden goed zijn geregeld.

\section{Brandveiligheid in private kwaliteitssystemen}

Sinds 2014 is brandveiligheid een aparte module binnen de Maatlat Duurzame Veehouderij. Vanaf 2015 zijn er daadwerkelijk MDV-stallen in gebruik genomen die brandveiligheidsinvesteringen hebben gedaan. Dit betreft vooral inspanningen op het gebied van beveiliging tegen oververhitting van elektromotoren in het dierverblijf, open uitvoering van kabelgoten tegen ongediertevraat, opslag van brandbare voer- en strooiselmaterialen buiten de dierverblijven, beschikbaarheid van brandblussers en aanwezigheid van een noodstroomaggregaat. Van de sinds 2013 gebouwde stallen is een toenemend aantal MDV-gecertificeerd: ca. $90 \%$ van de varkensstallen, meer dan $80 \%$ van de pluimveestallen en ca. $25 \%$ van de melkveestallen. De MDV-certificering blijft daarmee een interessant instrument voor versterking van brandveiligheid bij nieuwbouw van stallen. De ambitieniveaus worden binnen MDVkader regelmatig beoordeeld. Daarbij is afstemming over maatregelen en bijstelling van ambitieniveaus met de stakeholders binnen het Actieplan Stalbranden gewenst.

Opname van een periodieke agro-elektrakeuring (eens per 5 jaar) binnen het Beter Leven kenmerk van de Dierenbescherming is een belangrijke ontwikkeling. Het aantal stallen met Beter Leven kenmerk neemt toe: in 2016 betrof het circa 3000 stallen (zie fig. 7.1). Vrijwel alle bedrijven binnen de intensieve veehouderij zijn IKB-gecertificeerd. Opname van brandveiligheidseisen binnen IKB, waaronder in het bijzonder een periodieke elektrakeuring, zal een belangrijke stap voorwaarts zijn in het brandveiliger maken van bestaande stallen.

\section{(Toekomstige) ontwikkelingen binnen sectoren en brandveiligheid}

Toekomstige ontwikkelingen binnen de verschillende sectoren worden gekenmerkt door een afname van het aantal bedrijven en een voortzetting van de schaalvergroting. Nieuwe stallen voldoen uiteraard aan de brandveiligheidseisen binnen het Bouwbesluit die per 1-4-2014 zijn ingegaan (compartimentering technische ruimten; hogere brandklasse constructiematerialen). In alle sectoren is in toenemende mate sprake van automatisering in de stal. Dit laat zich soms lastig concentreren in een technische ruimte. Nieuw te installeren elektromotoren zijn beveiligd tegen oververhitting. Periodieke elektrokeuringen worden steeds meer gemeengoed. Een toenemend gebruik in de intensieve sectoren van luchtwassers voor emissiereductie en de wens tot energiebesparing kan als neveneffect hebben dat het interne stalklimaat verslechtert. Hoge relatieve luchtvochtigheid en ammoniakconcentraties vormen een extra risico voor corrosie aan elektrische installaties (verlichting, stopcontacten, elektromotoren). Door bouwblokrestricties worden in o.a. de varkens- en melkveehouderij weer diepe mestputten gebouwd met langdurige opslag in de stal. Vooral in de nawinter kan dit leiden tot veel schuimvorming op het mestoppervlak. Het schuim bestaat uit schadelijke en brandbare gassen en vormt een direct risico voor brand. Er zal in toenemende mate worden geproduceerd binnen welzijnsconcepten. Hierdoor neemt de vuurlast binnen dierverblijven naar verwachting toe (stro(oisel); ruwvoer). Restricties aan totaal bebouwd oppervlak zou uit oogpunt van o.a. brandveiligheid de voorkeur verdienen boven restricties aan de maximale omvang van het bouwblok.

De snelheid waarmee stallen binnen de dierlijke sectoren brandveiliger worden is (mede) afhankelijk van de vervangingstermijnen voor ruwbouw, stalinrichtingen en installaties. In fig. 8.1 zijn deze termijnen schematisch aangegeven. 


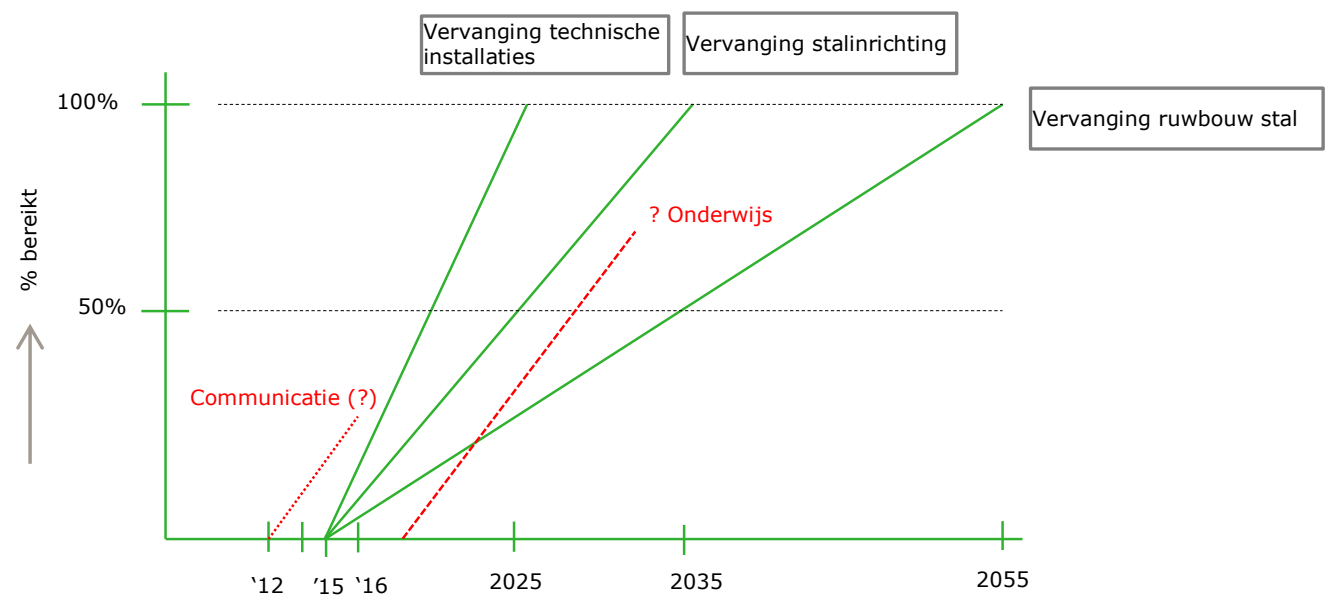

Figuur 8.1 Verwachte vervangingstermijnen stallen, stalinrichting en technische installaties vanaf 2015 en illustratie mogelijk bereik communicatie Actieplan over brandveiligheid en brandveilig werken periode 2012-2016

Fig. 8.1 laat zien dat het brandveiliger worden van ruwbouw van stallen binnen sectoren een proces van lange adem is (afschrijvingstermijn circa 40 jaar). Investeringen in stalinrichting, waaronder ook vervanging van dakisolatie, elektrische installaties, rioleringssystemen, binnenwanden en dergelijke, worden doorgaans binnen 20 jaar na dato vervangen. Technische installaties, waaronder voer- en drinkwaterinstallaties, ventilatiesystemen, mest- en eierbanden, luchtwassers, hokinrichting en dergelijke, kennen de kortste afschrijvingsduur, circa 10 jaar.

Dit betekent dat investeringen in een verbeterde brandveiligheid van technische installaties en daarna in brandveiliger stalinrichting, naast brandveiliger werken, het snelst tot effect kunnen leiden. Ter illustratie is in de figuur ook een ruwe inschatting gemaakt van het bereikte effect van communicatie en onderwijs. Bij communicatie is er van uitgegaan dat dit een tijdelijk karakter heeft en dat maar een beperkt deel van de veehouders hiermee wordt bereikt. Van het bereikte deel onderneemt ook weer een beperkt deel actie om stallen daadwerkelijk brandveiliger te maken of bewuster met brandgevaarlijke werkzaamheden om te gaan. Implementatie van een module over brandveiligheid in het agrarisch onderwijs heeft tot gevolg dat in principe alle toekomstige veehouders (en dierverzorgers) worden bereikt.

\section{Bluswatervoorziening in de toekomst}

Uit de interviews blijkt dat de bluswatervoorziening in de toekomst aandacht vraagt. De brandweer heeft voldoende bluswater bij zich om een beginnende brand te blussen. Als de brand het beginstadium voorbij is, is de belangrijkste focus van de brandweer om overslag naar naastgelegen stallen (of andere belendingen) te voorkomen. Voldoende afstand tussen stallen is de meest effectieve maatregel voor overslagpreventie. Het -preventief- aanleggen van een waterscherm is geen effectieve oplossing ${ }^{3}$.

Als stallen dicht op elkaar staan is voldoende bluswater essentieel om brandoverslag te voorkomen. Op dit ogenblik wordt vooral in bluswater voorzien door de drinkwaterleiding in de openbare weg. De hierop aangesloten brandkranen liggen daardoor meestal op grotere afstand van de stallen en leveren vanwege de ligging in het buitengebied vaak niet meer dan $30 \mathrm{~m}^{3}$ per uur. In de toekomst zal het gebruik van het drinkwaterleidingnet voor bluswater gaan verminderen. $\mathrm{Nu}$ al anticiperen brandweerkorpsen daar op door het aanschaffen van tankwagens met een waterinhoud van 15 tot 20 $\mathrm{m}^{3}$. In vergelijking met het huidige stelsel van brandkranen zal dit echter een vermindering van hoeveelheid en snelheid van beschikbaarheid van het bluswater betekenen. Extra bluswatervoorzieningen zoals open water, bassins (bijvoorbeeld infiltratievijvers in kader van de watertoets bij bedrijven die ontwikkelen) of grondwaterputten, zijn/blijven dan noodzakelijk ${ }^{4}$.

\section{Snelle diergeneeskundige hulp bij brand}

\footnotetext{
${ }^{3}$ Defensieve buiteninzet: warmtestraling en waterschermen (Brandweeracademie, 2015)

${ }^{4}$ De vuistregel voor blussing is 10 liter per minuut per $\mathrm{m}^{2}$ vuurfront. De vuistregel voor het voorkomen van overslag is 2 liter per minuut per $\mathrm{m}^{2}$ te beschermen oppervlak. Maar beide vuistregels staan ter discussie.
} 
De zelfredzaam van dieren is met name in de intensieve veehouderij beperkt of afwezig. Om de aantasting van dierenwelzijn zoveel mogelijk te beperken, kan de meest aangewezen handelwijze zijn om de dieren zo kort mogelijk na, of zelfs al tijdens een brand (koppelgewijs) te euthanaseren. In te zetten (koppelgewijze) euthanasiemethoden tijdens stalbranden mogen de veiligheid van de mensen in de nabijheid van de brand niet in gevaar brengen.

Van de methoden die zijn toegestaan voor euthanasie van dieren, zou de gasmethode het meest in aanmerking kunnen komen voor toepassing tijdens brand (Kluivers en Hindle, 2015). Het gaat dan om het gebruik van niet-brandbare gassen of (met gas gevuld) schuim, zoals $\mathrm{CO}_{2}$ gas. Bij pluimvee is de effectiviteit en welzijnsvriendelijkheid van deze methoden onder normale omstandigheden onderzocht, bij varkens niet. Voor een veilige toepassing is het noodzakelijk dat de stal of compartimenten in de stal van buitenaf met gas of schuim gevuld kunnen worden. Bij gebruik van schuim moet de dood bij de dieren niet door mechanische verstikking worden bewerkstelligd, maar door de werking van het gas. En dat wordt lastig in een stalbrandsituatie, waarin het schuim makkelijk wordt 'stukgefladderd' door dieren die in paniek zijn en de werkbaarheid mogelijk verminderd door de hoge temperaturen. Mede om die reden is het weinig zinvol om vervolgonderzoek naar de toepasbaarheid van deze methoden in stalbrandsituaties in te zetten. Kluivers en Hindle (2015) constateerden dat er behoefte is aan het uitwerken van een protocol dat voor dierenarts en hulpdiensten als leidraad kan dienen bij een stalbrand (logistieke organisatie, verantwoordelijkheden ten aanzien van de operatie, et cetera). KNMvD en Brandweer Nederland hebben hier inmiddels gezamenlijk een handreiking voor opgesteld ('Leidraad dierenarts bij stalbrand').

\section{Innovaties in brandveiligheid van stallen en voor dieren}

Innovaties in brandveiliger technische installaties, stalinrichtingselementen en ruwbouw kunnen een belangrijke impuls geven aan versterking van de brandveiligheid binnen de dierlijke sectoren (en aan bewustzijn ten aanzien van brandveiligheid). Daarbij kan bijvoorbeeld gedacht worden aan:

- Innovaties in werkbare rook- en branddetectiesystemen in dierverblijven Zoals ontwikkeling van camerasystemen in dierverblijven met softwarematige toevoeging van een branddetectiesysteem

- Automatische blussystemen die ook in de operationele bedrijfsvoering kunnen worden gebruikt, zoals watermistsystemen voor inweken van vloeren, koeling van dieren, vernevelen van bijvoorbeeld probiotica en dergelijke

- Innovaties die een gezonder binnenklimaat bevorderen, waardoor er minder corrosie optreedt, door voldoende ventilatie, emissiearme stalsystemen (in plaats van luchtwassers) en mestopslag buiten de stal (minder kans op methaanvorming)

- Ontwikkeling van corrosiebestendige brandslanghaspels, van belang in corrosieve ruimten zoals dierverblijven

- Innovaties in branddetectie in combinatie met het verlengen van de overlevingstijd bij brand en/of vergroten van de mogelijkheden voor evacuatie van dieren bij brand. [Dergelijke innovaties, zoals combinatie van branddetectie en automatische valwanden of valluiken, zitten in een (pril) onderzoekstadium]

- Innovaties waarbij brandveiligheidslabels worden gekoppeld aan materialen, onderdelen van huisvestingssystemen en dergelijke

De werkgroep Actieplan Stalbranden fungeert op dit moment (slechts) als aanspreekpunt voor innovaties in brandveiligheid binnen veestallen. Daadwerkelijk faciliteren van innovaties door het bedrijfsleven vraagt om een meer systematische en interactieve aanpak voor het stimuleren en opsporen van innovatieve ideeën. Te denken valt aan het bijvoorbeeld twee- of driejaarlijks organiseren van een innovatie-expo met betrekking tot brandveiligheid. Hierbij kan het bedrijfsleven haar innovaties in brandveiligheid demonstreren en vindt interactie plaats tussen de potentiele afnemers (de vraagkant) en producenten van stalsystemen en installaties. Het Actieplan Stalbranden kan vervolgens faciliteren in het valideren of demonstreren van perspectiefvolle innovaties in brandveiligheid op proef- of praktijkbedrijven. 


\section{Verbetermogelijkheden in registratie van stalbranden en oorzaken}

Het registreren van iedere stalbrand door Brandweer Nederland en onderzoek naar de oorzaak is een duidelijke verbetering ten opzichte van de situatie van voor het Actieplan, toen dit niet systematisch gebeurde. Het inzicht in de incidenties van stalbranden (waar de brandweer bij is geweest) en het aantal dierlijke slachtoffers is hierdoor naar verwachting toegenomen. Hetzelfde geldt voor het inzicht in de oorzaken van stalbranden, ook al blijven nog relatief veel oorzaken onbekend. 


\section{$9 \quad$ Conclusies}

Door de relatief korte looptijd van het Actieplan, en daarmee de tijd waarin ingezette activiteiten tot een effect hebben kunnen leiden, was het niet zinvol om een effectmeting van deze activiteiten te baseren op veranderingen in het aantal stalbranden en aantal dieren dat hierbij is omgekomen (directe kwantitatieve effectmeting). Daarnaast was het binnen de kaders van de opdracht niet mogelijk om uitgebreid kwantitatief onderzoek te doen naar veranderingen in brandveiligheid van stallen en in bewustzijn en brandveilig handelen in de praktijk. De navolgende conclusies over het effect van het Actieplan 2012-2016 zijn door de onderzoekers afgeleid uit o.a. het kwalitatieve onderzoek (interviews), de beknopte internetenquête onder veehouders en expertkennis over toekomstige ontwikkelingen. Het is niet altijd mogelijk om 'harde' conclusies te trekken.

\subsection{Brandveilige bedrijfsvoering}

\section{Activiteiten Actieplan}

In de looptijd 2012-2016 is binnen realisatiespoor A (Een brandveilige bedrijfsvoering) van het Actieplan veel inspanning gepleegd om het bewustzijn van veehouders (en erfbetreders) met betrekking tot brandveiligheid te vergroten en handelingsperspectieven te bieden. Er zijn 35 bijeenkomsten met veehouders en erfbetreders gehouden met brandveiligheid van dieren in veestallen als onderwerp, met presentaties van verschillende materiedeskundigen (LTO, brandweer, verzekeraars e.a.). Via reguliere informatiekanalen voor veehouders en erfbetreders is in diverse artikelen gecommuniceerd over het Actieplan Stalbranden, de aanpassingen van het Bouwbesluit, tips en tools. Ondanks inspanningen is het nog niet gelukt om brandveiligheid voor dieren in veestallen opgenomen te krijgen in reguliere onderwijsmodules van het agrarisch onderwijs.

\section{Evaluatie}

Hierna zijn de belangrijkste conclusies uit het onderzoek naar het effect van ingezette activiteiten op brandveilig werken en zinvolle vervolgactiviteiten samengevat:

* Het bewustzijn van bepaalde typen veehouders met betrekking tot brandveiligheid lijkt te zijn toegenomen in de looptijd van het Actieplan (interviews, internetenquete). Vooral schaalvergroters, relatief jonge grootschalige ondernemers die bezig zijn met bedrijfsontwikkeling, zijn zich bewust van het belang van brandveilig werken en brandveilige stallen, o.a. om bedrijfscontinuïteit te waarborgen in geval van brand (verzekerbaarheid). Bij andere typen ondernemers, de verbreders (multifunctioneel/meer extensieve houderij) en de uitfaseerders (ondernemers die binnen afzienbare tijd stoppen), is het bewustzijn van brandveiligheid niet of nauwelijks veranderd in de afgelopen 4 jaren. De verbreder is naar verwachting aanspreekbaar op aspecten van brandveiligheid; voor de uitfaseerder zal dit minder het geval zijn.

* Activiteiten op het gebied van voorlichting over brandveiligheid van veestallen en de dieren daarin verdienen continue voortzetting. Brandveiligheid van stallen zal sterk onder druk blijven staan door de relatief geringe kans op stalbrand (ondanks de grote impact), de kostprijsgedreven afwegingen en de regeldruk op o.a. milieugebied, en dient mede om die reden regelmatig onder de aandacht te worden gebracht. Voorlichtende activiteiten aan veehouders dienen bij voorkeur te worden afgestemd op de verschillende typen ondernemers, het meest geëigende communicatiemiddel voor het type ondernemer en de onderwerpen waarop zij aanspreekbaar zijn.

- Schaalvergroters zullen naar verwachting vooral openstaan voor voorlichting over:

- innovaties in optimale benutting van het bouwblok en brandveiligheid

- (betaalbare) innovaties in het ontwerp van stallen in relatie met o.a. brandveiligheid 
- innovatieve systemen zoals snelle detectie met automatische blussystemen, in het bijzonder in geval van grotentijds onbemenste stallen

- scholing van medewerkers in brandveilig werken en hoe te handelen bij brand (o.a. via agrarisch onderwijs, cursussen)

- deelname aan praktijknetwerken

- Verbreders lijken een belangrijke doelgroep voor kennisuitwisseling en het bieden van praktische en betaalbare oplossingen voor brandveilige stallen en brandveilig werken. Oplossingen gericht op de specifieke brandveiligheidsrisico's en -kansen (uitloop in relatie met evacuatie van dieren) die produceren binnen welzijnsconcepten met zich mee kan brengen. Zij zullen naar verwachting aanspreekbaar zijn op het belang van brandveiligheid voor mens én dier

- Uitfaseerders worden naar verwachting niet of nauwelijks bereikt via voorlichting.

* Werkzaamheden zijn nog steeds belangrijke oorzaken van stalbrand. Brandgevaarlijke werkzaamheden zijn in circa $12 \%$ van de stalbranden als oorzaak achterhaald (bij ruim de helft van de stalbranden in 2014-2016 heeft men geen oorzaak gevonden), uiteenlopend van ca. $6 \%$ in de pluimveehouderij en ca. $20 \%$ in de rundveehouderij (kalveren, overig rundvee). Voorlichting over brandveilig werken dient zich niet alleen te richten op veehouders, maar ook op professionele bedrijven die (brandgevaarlijke) werkzaamheden in en aan stallen uitvoeren (installateurs, dakdekkers, ..): ook daar gaat het soms mis, zoals blijkt uit oorzaken van stalbranden in de periode 2014-2016. Communicatie in de vakpers over oorzaken van stalbranden als gevolg van werkzaamheden door professionele bedrijven en aantallen dieren die erbij zijn omgekomen kan de voorlichting over brandveilig werken aan deze doelgroep ondersteunen. Via voorlichting (en verzekeraars) kunnen veehouders bewust worden gemaakt van het belang om een gerenommeerd bedrijf in te schakelen voor brandgevaarlijke werkzaamheden, en van het belang om vooraf te checken hoe brandpreventie bij uitvoering van de werkzaamheden is geborgd.

* Praktijknetwerken in de varkens-, pluimvee- en rundveehouderij hebben binnen het Actieplan Stalbranden een aantal praktische en waardevolle oplossingen aangedragen voor o.a. brandveiliger werken. Praktijknetwerken en studiegroepen van veehouders kunnen een belangrijke ondersteunende rol spelen in het genereren, toetsen en delen van praktische oplossingen ter versterking van de brandveiligheid op praktijkbedrijven. Daarbij kan het gaan om oplossingen voor brandveilig werken, maar ook over optimale inrichtingen van het bouwblok bij nieuwbouw van stallen, brandveilige hokinrichtingen, de wijze waarop elektromotoren zo veel mogelijk buiten dierverblijven kunnen worden gehouden et cetera.

* Realisatie van opname van brandveiligheid voor dieren in veestallen in het reguliere onderwijsprogramma van het agrarische onderwijs is belangrijk om toekomstige veehouders en dierverzorgers bewust te maken van het belang ervan en te voorzien van de benodigde kennis en tools. Opname van brandveiligheid in agrarische onderwijsmodules vraagt om voortgaande inzet binnen het Actieplan Stalbranden.

\subsection{Brandveilige stallen}

\section{Activiteiten Actieplan}

In de looptijd 2012-2016 is binnen de realisatiesporen B en C (Brandveilige stallen respectievelijk stimulering ervan) van het Actieplan inspanning gepleegd om de kans op ontstaan van brand te reduceren. O.a. stimuleren van opname van periodieke elektrakeuringen in private kwaliteitssystemen (gerealiseerd in Beter Leven; voor IKB nog in discussie), en door de mogelijkheden binnen Europees recht voor een verbod op open-vuur heaters na te gaan (niet mogelijk; voorlichting wordt nu opgezet). Daarnaast is ingezet op versterken van het kennisniveau bij stallenbouwer, gemeente en veehouder over wet- en regelgeving (via communicatie langs meerdere kanalen en een BZKhelpdesk). Per 1-1-2014 is met een aparte module voor brandveiligheid in de Maatlat Duurzame Veehouderij beloning van investering in brandveiligheid via fiscale voordelen gerealiseerd. Er is ingezet op aanpassen en implementeren van brandveiligheidseisen voor veestallen in Bouwbesluit 2012 (wijziging Bouwbesluit per 1-4-2014). Er is ingezet op het ontwikkelen van handvatten voor veestallen voor beoordeling van gelijkwaardigheid van brandcompartimenten $>2.500 \mathrm{~m}^{2}$; met dit doel 
worden bijlagen bij de NEN-normen 6060 en 6079 ontwikkeld. Er is actie ondernomen om brandveiligheid voor dieren in veestallen onderdeel te maken van integrale handhavingsstrategieën van gemeenten. Dit bleek niet mogelijk, in plaats daarvan heeft men Omgevingsdiensten gevraagd om brandveiligheid tijdens bedrijfsinspecties aandacht te geven (leaflet in voorbereiding). Daarnaast is ingezet op verbetering van de samenwerking tussen dierenarts en brandweer (protocol euthanasie in voorbereiding). En is de werkgroep Actieplan aanspreekpunt voor het bedrijfsleven ten aanzien van het stimuleren van innovaties in detectiesystemen.

\section{Evaluatie}

Hierna zijn de belangrijkste conclusies uit de evaluatie over het effect van ingezette activiteiten op brandveilige stallen en zinvolle vervolgactiviteiten samengevat:

\section{Huidige situatie}

* Verandering in kans op brand bij nieuwbouw. De overall kans op brand met dierlijke slachtoffers bij nieuwbouw na 1-4-2014 is in gunstige zin is veranderd. Dit hangt samen met de nieuwe voorschriften in het Bouwbesluit over compartimentering van technische ruimten en de hogere brandklasse van constructie/-isolatiematerialen. Het hangt ook samen met keuringseisen die verzekeraars en/of gemeenten stellen aan elektrische apparaten bij oplevering van de nieuwbouw en de eisen van verzekeraars voor periodieke keuring na ingebruikname ervan. Er wordt bij nieuwbouw enige toename gezien in branddetectie in de technische ruimte. Ook lijkt men bij nieuwbouw alerter te zijn op de aanwezigheid van handblusmiddelen.

* Verandering in kans op brand bij bestaande stallen. Voor bestaande stallen in de verschillende sectoren schatten we in dat de brandveiligheid in de afgelopen jaren in geringe mate is verbeterd. Dat hangt vooral samen met de gunstige ontwikkeling die op gang is gekomen in periodieke keuring van elektrische apparaten in de verschillende sectoren, m.n. vanwege eisen in het kader van de brandverzekering. Andere substantiële ontwikkelingen zijn er in bestaande stallen naar verwachting niet geweest. Het is belangrijk dat een periodieke elektrakeuring gemeengoed wordt binnen de verschillende sectoren, voor bestaande stallen en na oplevering van nieuwgebouwde stallen.

* Kennisniveau wet- en regelgeving. Er zijn verschillen waargenomen in interpretatie van bestaande wet- en regelgeving over brandveiligheid tussen gemeenten en tussen veiligheidsregio's, ; dit betreft toepassing van gelijkwaardigheid en uitbreiding van bestaande stallen. Dit heeft ook effect op interpretatie van regelgeving door stallenbouwers en veehouders. Een voortzetting/verdieping van de voorlichtende activiteiten binnen het actieplan over brandveiligheidseisen in wet- en regelgeving is gewenst. Aannemers lijken regelmatig af te wijken van het bouwplan, uit kosten- of praktische overwegingen. Specifieke voorlichting over (het belang van) brandveiligheid en bestaande wet- en regelgeving richting deze doelgroep is wenselijk. Communicatie over oorzaken van een snelle branduitbreiding via bouwmaterialen van bepaalde brand- en rookklassen en aantallen omgekomen dieren zal daarbij ondersteunend kunnen zijn. Evenals aannemers wijzen op hun verantwoordelijkheid en aansprakelijkheid als ze plan-afwijkend bouwen.

* Handvatten voor beoordeling gelijkwaardigheid. Gemeenten hebben sterk behoefte aan landelijke handvatten voor beoordeling van gelijkwaardigheid. Gemeenten hopen en verwachten dat de in ontwikkeling zijnde bijlagen voor veestallen bij de NEN-normen 6060 en 6079 in de toekomst een goed beoordelingskader zullen bieden. De inhoud ervan is op het moment van afronden van deze studie nog pas kort openbaar en daarmee niet in alle facetten te beoordelen binnen deze evaluatie.

* Handhaven op brandveiligheid bij oplevering nieuwbouw. Gemeenten controleren wisselend op de realisatie van brandveiligheidsaspecten bij nieuwbouw conform het vergunde bouwplan. Bij oplevering is niet altijd meer zichtbaar welke materialen zijn gebruikt. Gemeenten kijken doorgaans alleen verder als er ernstige 
vermoedens van onrechtmatigheden zijn. Met de inwerkingtreding van de Wet

Kwaliteitsborging voor het Bouwen verschuift met ingang van 2018 de preventieve toets op de plannen en het toezicht op uitvoering van nieuwbouw en verbouw van de gemeente naar een private kwaliteitsborger. Uitzondering: indien gebruik wordt gemaakt van een gelijkwaardige oplossing en/of bij bouwwerken die uit meer dan twee bouwlagen bestaan blijft de toets vooralsnog plaatsvinden door de gemeente. Private toets en toezicht op de bouw door de bouwspecialisten zelf kan volgens de rijksoverheid kwaliteitsvoordelen hebben. Voorwaarden hierbij zijn dat het toezicht op toezicht (door een onafhankelijke toezichthouder) en verantwoordelijkheden en aansprakelijkheden van de private kwaliteitsborgers goed zijn geregeld.

* Handhaven op brandveiligheid bij bestaande stallen. De werkgroep Actieplan geeft aan dat het voor gemeenten niet mogelijk is om brandveiligheid onderdeel te laten uitmaken van hun integrale handhavingsstrategie. Veestallen hebben geen prioriteit in handhaving. Milieuinspecties door Omgevingsdiensten (frequentie 1 keer per 5-10 jaar, grote bedrijven het meest frequent) bieden in potentie een goede gelegenheid om ondernemers, naast de formele milieu-inspectie, te attenderen op risico's met betrekking tot brandveiligheid.

* Er wordt in toenemende mate geproduceerd binnen welzijnsconcepten en we zien een toename in bouw van stallen met een keurmerk voor integraal duurzame veehouderij (o.a. Keten Duurzaam Varkensvlees, Beter Leven, Maatlat Duurzame Veehouderij). Koppeling van brandveiligheidsmaatregelen aan private kwaliteitskeurmerken zoals MDV en Beter Leven is en blijft een belangrijke ingang voor versterking van brandveiligheid, bij nieuwbouw en voor bestaande stallen. Opname van een periodieke elektrakeuring binnen de sectorbrede IKB- of andere kwaliteitssystemen biedt een belangrijke extra mogelijkheid om de kans op ontstaan van brand in alle stallen op korte termijn te reduceren of beperkt te houden. Voor stimuleren van brandveiligheid van alle stallen spelen naast private (sectorbrede) kwaliteitssystemen ook verzekeraars (voorwaarden in brandverzekering) een belangrijke rol.

* Snelle diergeneeskundige hulp bij brand. Om dierenleed te beperken is gewenst om niet te redden dieren tijdens of na stalbrand zo snel mogelijk te euthanaseren. Zowel $\mathrm{CO}_{2}$-gas als schuim (op waterbasis) zijn effectief bevonden als dodingsmethode bij pluimvee in (intacte) stallen. Er is geen literatuur beschikbaar over toepassing van dergelijke methoden tijdens stalbranden, en niet over de toepassingsmogelijkheden en effectiviteit van deze methoden voor koppelgewijs euthanaseren van varkens bij/na stalbrand. Het perspectief van inzet van dergelijke methoden tijdens een stalbrand lijkt gering (hoge temperaturen en door paniek naar verwachting veel fladderende/onrustige dieren, waardoor het schuim minder werkzaam zal zijn). Er is behoefte aan afstemming tussen brandweer en dierenarts over verantwoordelijkheden en de handelwijze gericht op de zorg voor de dieren in en/of na een stalbrand. KNMvD en Brandweer Nederland hebben hiervoor gezamenlijk een handreiking 'Leidraad Dierenarts bij stalbrand' opgesteld, waarin een stappenplan voor de dierenarts met o.a. instructie over afstemming met hulpdiensten is opgenomen.

\section{(Toekomstige) ontwikkelingen en brandveiligheid}

* De beperkingen die aan de omvang van bouwblokken worden gesteld, zorgen er in combinatie met de toenemende schaalvergroting bij nieuwbouw voor dat nieuwe stallen aan bestaande stallen worden gebouwd of er dicht bij worden geplaatst. Dit vormt bij brand een extra risico op brandoverslag tussen brandcompartimenten en/of op dierlijke slachtoffers in naastgelegen compartimenten door binnenkomen van hete of giftige lucht. Door restricties aan de bouwblokgrootte worden in o.a. de varkens- en melkveehouderij stallen met diepe mestputten gebouwd met langdurige opslag in de stal. Vooral in de nawinter kan dit leiden tot veel schuimvorming (schadelijke en brandbare gassen) op het mestoppervlak en vormt een direct risico voor brand. Voor de melkveehouderij wordt ingeschat dat de evacuatiekansen van dieren bij brand verminderen indien bij nieuwbouw een extra spant aan de bestaande stal wordt gebouwd. Restricties aan totaal bebouwd oppervlak verdient uit oogpunt van o.a. brandveiligheid de voorkeur boven restricties aan de maximale omvang van het bouwblok. 
* Toekomstige ontwikkelingen binnen de verschillende sectoren worden gekenmerkt door een afname van het aantal bedrijven en een voortzetting van de schaalvergroting. Dit zal een uitfasering tot gevolg hebben van met name kleinere/oudere stallen. Dit proces wordt mogelijk versneld door (milieu-)wetgeving. Nieuwe stallen zijn conform de eisen van het Bouwbesluit qua constructie (o.a. brandklasse isolatiematerialen) brandveiliger. In alle sectoren is in toenemende mate sprake van automatisering in de stal. Dit laat zich soms lastig concentreren in een technische ruimte. Nieuw te installeren elektromotoren zijn beveiligd tegen oververhitting. Periodieke elektrokeuringen worden steeds meer gemeengoed. Een toenemend gebruik in de intensieve sectoren van luchtwassers voor emissiereductie en de wens tot energiebesparing kan als neveneffect hebben dat het interne stalklimaat verslechtert. Hoge relatieve luchtvochtigheid en ammoniak-concentraties vormen een extra risico voor corrosie aan elektrische installaties (verlichting, stopcontacten, elektromotoren). (Afspraken over) onderhoud aan dergelijke installaties na oplevering van nieuwbouw vormt (mede) uit oogpunt van brandveiligheid een belangrijk aandachtspunt.

* Schaalvergroting en grenzen aan gelijkwaardigheid. De voortgaande schaalvergroting pleit voor het stellen van een bovengrens aan de omvang van brandcompartimenten waarin dieren verblijven, onderbouwd via een zo objectief mogelijk inschatting van risico = kans $\mathrm{x}$ effect. Beoordeling van gelijkwaardigheid van grote brandcompartimenten op basis van kans op ontstaan en uitbreiding van stalbrand doet slechts ten dele recht aan het gelijk houden van de brandveiligheid voor de dieren: de kans op brand kan gelijkwaardig zijn, de impact van brand (dierlijke slachtoffers) beduidend hoger bij grote brandcompartimenten. De concept-bijlage van de NEN-norm 6060 kent een bovengrens voor de compartimentsgrootte van veestallen (afhankelijk van voorzieningen en diersoort. De concept-bijlage van de NEN 6079 die de maximale compartimentsgrootte van veestallen bepaalt op basis van een risicobenadering, houdt rekening met dierenleed, maar kent geen bovengrens. De inhoud van de bijlagen is op het moment van afronden van dit rapport nog te kort openbaar en daarmee niet in alle facetten te beoordelen in deze evaluatie.

* Vervangingstermijnen. De snelheid waarmee bestaande stallen binnen de veehouderijsectoren brandveiliger kunnen worden is (mede) afhankelijk van de vervangingstermijnen voor ruwbouw, stalinrichtingen en installaties (in figuur 8.1 (hoofdstuk 8) zijn deze termijnen schematisch aangegeven). Het aangegeven vervangingsritme laat zien dat, naast communicatie en onderwijs over brandveiligheid en brandveilig werken, investeringen in een verbeterde brandveiligheid van technische installaties (vervangingstermijn ca. 10 jaar) het snelst tot effect zullen leiden. Technische installaties zijn op dit moment in de meeste sectoren de belangrijkste oorzaak van het ontstaan van stalbranden.

* Bluswatervoorziening in toekomst. In de toekomst zal het gebruik van brandkranen die zijn aangesloten op het drinkwaternet geleidelijk aan gaan verminderen. Om in die gevallen voldoende bluswatercapaciteit nabij grote veestallen beschikbaar te houden, zullen naast tankwagens van de brandweer extra voorzieningen zoals open water, bassins (bv. infiltratievijvers i.k.v. de watertoets) of grondwaterputten noodzakelijk zijn.

* Innovaties. Er zijn nog geen praktijkrijpe, blijvend goed functionerende rook-/brand detectiesystemen voor in de dierverblijven op de markt (vooral zinvol in combinatie met automatische blussystemen). Innovaties in brandveiliger technische installaties en stalinrichtingselementen kunnen een impuls geven aan versterking van de brandveiligheid binnen de dierlijke sectoren (en aan bewustzijn ten aanzien van brandveiligheid). De haalbaarheid van implementatie van dergelijke innovaties wordt (aanzienlijk) vergroot als het meer doelen dient dan alleen brandveiligheid, d.w.z. operationele doelen binnen de bedrijfsvoering. Innovaties kunnen binnen het Actieplan Stalbranden worden gefaciliteerd via innovatie-expo's met bedrijfsleven en potentiele afnemers. Het Actieplan kan vervolgens faciliteren in het laten valideren of demonstreren van perspectiefvolle innovaties op proef- of praktijkbedrijven. 


\subsection{Stalbranden en oorzaken}

\section{Activiteiten Actieplan}

In de looptijd 2012-2016 is binnen realisatiespoor D (Verbeterd inzicht in oorzaken van stalbranden en betere beheersbaarheid) van het Actieplan ingezet op een betere registratie van stalbranden door Brandweer Nederland (gerealiseerd sinds 2014) en het systematisch onderzoeken van de oorzaken van stalbranden daarbij (eveneens gerealiseerd sinds 2014). Per jaar worden er door Brandweer Nederland overzichten gegenereerd met de stalbrandincidenten waarbij zij zijn opgetreden, type bedrijf, aantal dieren dat is gered c.q. omgekomen en vermoedelijke oorzaak van de brand, inclusief eventuele bijzonderheden.

\section{Evaluatie}

Hierna zijn de belangrijkste conclusies uit de evaluatie over het effect van ingezette activiteiten op brandveilige stallen en zinvolle vervolgactiviteiten samengevat:

* Sinds 2014 registreert Brandweer Nederland i.s.m. het Verbond van Verzekeraars iedere stalbrand waar de brandweer is opgetreden. Het aantal stalbranden in de periode 2014-2016 en de daarbij omgekomen dieren zijn beschreven in tabel 4.1 (hoofdstuk 4). De kans op stalbrand is ook in de jaren 2014-2016 relatief klein, de impact (het effect) is nog steeds groot gezien de aantallen dieren die erbij omkomen.

* Het registreren van iedere stalbrand door Brandweer Nederland en onderzoek naar de oorzaak is een duidelijke verbetering ten opzichte van de situatie van voor het Actieplan, toen dit niet systematisch gebeurde. Het inzicht in het werkelijke aantal stalbranden (waar de brandweer bij is geweest) en het werkelijke aantal dierlijke slachtoffers is hierdoor naar verwachting verbeterd.

* Hetzelfde geldt voor het inzicht in de oorzaken van stalbranden (zie tabel 4.2 hoofdstuk 4), met de kanttekening dat nog relatief veel oorzaken onbekend blijven (bij ruim 55\% van de stalbranden). Voor zover oorzaken bekend zijn, vallen nog steeds de meeste dierlijke slachtoffers door stalbranden met een technische oorzaak (kortsluiting, oververhitting, zelfontbranding werktuigen). Verbeteringen op dit vlak blijven nadrukkelijk aandacht verdienen binnen het Actieplan Stalbranden. Daarnaast zijn in 2016 veel varkens omgekomen als gevolg van brand door menselijk handelen. Wat opvalt ten opzichte van eerdere jaren is het aantal stalbranden en dierlijke slachtoffers door blikseminslag. De verwachting is dat dit in de toekomst niet minder zal worden onder invloed van klimaatverandering, en daarmee een (nieuw) aandachtspunt uit oogpunt van brandveiligheid.

* Registratie van stalbranden en systematisch onderzoek naar de oorzaken door Brandweer Nederland blijft een zinvolle activiteit en verdient verdere uitbouw. Samenwerking met het Verbond voor Verzekeraars is daarbij aan te bevelen (Brandweer Nederland en het Verbond van Verzekeraars hebben al een samenwerkingsovereenkomst waar dit in zou passen). De huidige registratie is een waardevolle eerste aanzet die verdere ondersteuning en uitbouw verdient. Ondersteuning bijvoorbeeld via het faciliteren van een digitale vragenlijst voor stalbranden met dierlijke slachtoffers conform de handelwijze bij woningbranden in geval van menselijke slachtoffers. 


\section{Advies}

Uit de evaluatie komt naar voren dat het nuttig is om een follow up te geven aan het Actieplan Stalbranden 2012-2016. Geadviseerd wordt om de belangrijkste focus voor een follow up in de komende jaren te leggen bij de onderstaande activiteiten. Daar is de belangrijkste slag te maken in versterken van brandveiligheid voor dieren in bestaande stallen (en tevens bij nieuwbouw).

\section{Prioriteiten:}

> Bevorderen van brandveiligheid van technische installaties (voer-/drinkwaterinstallatie, ventilatiesysteem, verwarmingssysteem, regelcomputer, luchtwassers, melk- en koelapparatuur, aandrijving mest-/eierbanden, aandrijving mestschuiven/-robotjes e.d.).

> Bevorderen van brandveilig werken (door veehouders/dierverzorgers en professionele bedrijven zoals installateurs en dakdekkers) via voorlichting, communicatie, praktijknetwerken/ studieclubs en onderwijs

$>$ Bevorderen van alternatieve bluswatervoorzieningen op of nabij veehouderijbedrijven, daar waar de aanwezigheid van brandkranen op het drinkwaternet in de toekomst mogelijk vermindert.

$>$ Onderzoeken van een redelijke bovengrens aan grote brandcompartimenten (via een zo objectief mogelijke inschatting van risico = kans $x$ effect (d.i. potentieel aantal dierlijke slachtoffers) en bevorderen van opname ervan in wet- en regelgeving. Het is op dit ogenblik nog niet goed in te schatten of de bijlage van de norm NEN 6060 voorziet in een redelijke bovengrens. De bijlage bij de norm NEN 6079 voorziet in ieder geval niet in een bovengrens.

$>$ De brandveiligheid van veestallen voor mens en dier inbrengen als relevante factor voor het ruimtelijke ordeningsbeleid van provincies en gemeenten. Restricties aan totaal bebouwd oppervlak verdienen uit oogpunt van o.a. brandveiligheid de voorkeur boven restricties aan de maximale omvang van het bouwblok.

$>$ Voortzetten en waar mogelijk verder uitbouwen van de registratie van stalbranden en oorzaken ervan door Brandweer Nederland in samenwerking met verzekeraars. Overweeg de opzet van een digitaal registratiesysteem voor stalbranden met dierlijke slachtoffers conform de werkwijze in geval van humane slachtoffers bij woningbranden.

\section{Deeladviezen m.b.t. brandveilig werken}

- Activiteiten van het Actieplan op gebied van voorlichting over brandveiligheid van veestallen en brandveilig werken verdienen continue voortzetting. Communicatie afstemmen op type ondernemer: Schaalvergroter-Verbreder-Uitfaseerder (zie conclusies in 9.1)

- (Blijf) opname stimuleren van brandveiligheid als aparte module in het reguliere agrarische onderwijs.

- $\quad$ Richt extra voorlichtingsactiviteiten op professionele bedrijven (dakdekkers, installateurs) inclusief informatie over incidentie van stalbranden als gevolg van professionele werkzaamheden.

- $\quad$ Richt specifieke voorlichtingsactiviteiten op versterking van bewustwording brandveiligheid bij aannemers van veestallen.

- Blijf praktijknetwerken/studieclubs benutten voor genereren, toetsen en delen van praktische oplossingen ter versterking van brandveiligheid op praktijkbedrijven. 


\section{Deeladviezen m.b.t. brandveilige technische installaties}

- Bevorder inbedding van periodieke elektrakeuringen in sectorbrede kwaliteitssystemen (t.b.v. onderhoud, tijdige vervanging)

- Stimuleer innovaties in brandveiligheid van technische installaties (ook op gebied van beveiliging oververhitting i.c.m. bluspatronen/-systemen; brandklasse mestbanden e.d.).

- Stimuleer/ondersteun plaatsing van bliksemafleiders op staldaken, via opname in kwaliteitssystemen, subsidie- of fiscale stimuleringsregelingen (o.a. MDV), verzekeraars of anderszins.

- Neem activiteiten ter bevordering van toekomstige alternatieve beschikbaarheid van bluswater in het Actieplan op.

- Faciliteer innovaties in brandveiligheid van technische installaties en stalinrichtingen binnen het Actieplan, o.a. via innovatie-expo's en validatie-/demonstratietrajecten van perspectiefvolle ontwikkelingen op proef- of praktijkbedrijven.

- Versterk de communicatie over interpretatie regelgeving voor aantonen van gelijkwaardigheid van (grote) stallen en bij uitbreiding van bestaande stallen bij gemeenten, stallenbouwers en veehouders. Ga na of, en zo ja welke bovengrens kan worden gesteld aan grote brandcompartimenten onderbouwd vanuit risico $=$ kans $\mathrm{x}$ effect.

\section{Deeladviezen m.b.t. inzicht in stalbranden en oorzaken}

- Blijf de registratie van stalbranden en oorzaken door Brandweer Nederland (i.s.m. Verbond van Verzekeraars) voortzetten.

- Faciliteer het digitaal invullen en verwerken van vragenlijsten bij stalbranden met dierlijke slachtoffers conform de aanpak bij woningbranden.

- Overweeg doorvoering van de volgende aanpassingen in de registratie van stalbranden en oorzaken:

- Beschrijf duidelijk om welke veehouderijtak het gaat. Opsplitsing van de grote takken bij voorkeur in vleeskuikens, leghennen, overig pluimvee, varkens, vleeskalveren, melkvee, overig rundvee.

- Geef aan met welk houderijsysteem en/of voor welk specifiek marktconcept wordt geproduceerd: regulier, welzijnsconcept, wel/geen uitloop, ..

- Registreer de leeftijd van de betrokken stal. Bij recente stallen: op welke datum de omgevingsvergunning voor het bouwen is verleend (vóór of na 1-4-2014)

- Geef een heldere omschrijving van de oorzaak volgens vooraf vastgestelde categorieën. Voorstel categorieën: elektriciteit/kortsluiting, zelfontbranding/ oververhitting werktuig in veestal, zelfontbranding/oververhitting werktuig in opslag hooi/stro/houtsnippers/.., broei in hooi/stro/houtsnippers/mestopslag, open-vuur heater, werkzaamheden veehouder, werkzaamheden professioneel bedrijf, blikseminslag, brandstichting, anders.

- Blijf aangeven op welke wijze dieren zijn gered.

- In geval van dierlijke slachtoffers: geef tevens in de registratie van brandoorzaken de oorzaak van het omkomen van dieren: a) als direct gevolg van rook/brand, b) door uitvallen van de ventilatie in aanpalend dierverblijf, c) door stress van evacuatie e.d.

\section{Kostenindicatie prioritaire maatregelen bestaande stallen}

Hieronder is een kostenindicatie gegeven van relevante maatregelen ter bevordering van brandveiligheid van bestaande veestallen (en tevens nieuwbouw), die binnen een follow up op het Actieplan prioriteit verdienen. 


\begin{tabular}{|c|c|c|}
\hline Maatregel voor (bestaande) stallen & Indicatie kosten ( $\mathrm{C}$ excl. BTW) & Sectoren \\
\hline $\begin{array}{l}\text { Periodieke elektrakeuring: } \\
\text { *opp. bedrijfsgebouwen }<750 \mathrm{~m}^{2} \\
\text { *opp. bedrijfsgebouwen } 750-4000 \mathrm{~m}^{2} \\
\text { *opp. bedrijfsgebouwen } 4000-8000 \mathrm{~m}^{2} \\
\text { *opp. bedrijfsgebouwen }>8000 \mathrm{~m}^{2}\end{array}$ & $\begin{array}{l}€ 395 \\
€ 595 \\
€ 845 \\
€ 995\end{array}$ & alle \\
\hline $\begin{array}{l}\text { Elektromotoren voorzien van beveiliging tegen } \\
\text { oververhitting }\end{array}$ & $\begin{array}{r}\text { Temperatuurvoelers tot } 160^{\circ} \text { in apparaten } \\
€ 100-€ 200\end{array}$ & alle \\
\hline Brand- en rookdetectiesysteem in technische ruimte & $\begin{array}{r}€ 100 \text {, met doormelding naar telefoon } \\
€ 400\end{array}$ & alle \\
\hline $\begin{array}{l}\text { Directe luchtafzuiging onder roosters in mestputten } \\
\text { voor afvoer (schuim) gevaarlijke gassen }\end{array}$ & Ca. $€ 3.000$ per afdeling & m.n. varkens \\
\hline $\begin{array}{l}\text { Aparte stalling voor (zelfontbrandbare) voer- } \\
\text { /werktuigen }\end{array}$ & Eenvoudige schuur ca. $€ 150,-/ \mathrm{m}^{2}$ & m.n. melkvee \\
\hline Bliksemafleider op dak van stal & Ca. $€ 7.500$ voor stal van $1000 \mathrm{~m}^{2}$ & alle \\
\hline $\begin{array}{l}\text { Indien nodig bluswatervoorziening op bedrijf } \\
\text { aanleggen }\end{array}$ & $\begin{array}{r}€ 15.000 \text { (geboorde put) } \\
€ 5.000 \text { (bluswatervijver/Wadi) }\end{array}$ & $\begin{array}{l}\text { alle } \\
\text { (m.n. grote } \\
\text { bedrijven) }\end{array}$ \\
\hline Objectinformatiekaart ten behoeve van brandweer & $€ 250$ tot $€ 700$ & alle \\
\hline
\end{tabular}

[Voor kostenindicaties van andere mogelijke aanpassingen in technische voorzieningen uit oogpunt van brandveiligheid wordt verwezen naar bijlage 7, waarin een kostenoverzicht uit rapport 'Onderzoek naar brandveiligheid voor dieren in veestallen van WUR/IFV uit 2012 is opgenomen] 


\section{Literatuur}

Bokma-Bakker, M.H., R.R. Hagen, S. Bokma, B. Bremmer, H.H. Ellen, H. Hopster, F. Neijenhuis, I. Vermeij en J. Weges, 2012. Onderzoek naar de brandveiligheid voor dieren in veestallen. Knelpunten en verbetermogelijkheden. Wageningen UR Livestock Research, rapport nr. 641.

Brandweeracademie, 2014. Risicovergelijking brandveiligheid van stallen groter dan $2500 \mathrm{~m}^{2}$ met stallen tot $2500 \mathrm{~m}^{2}$. Brandweeracademie is onderdeel van Instituut Fysieke Veiligheid.

Kluivers-Poodt, M. en V.A. Hindle, 2015. Euthanasie van dieren bij stalbranden. Wageningen Livestock Research, vertrouwelijk rapport nr. 410.

KWIN. 2016. Kwantitatieve Informatie Veehouderij 2016-2017. Wageningen Livestock Research, KWIN Handboek 30.

Looije M. en M. Smit, 2010. Brand in veestallen. Onderzoek naar de ernst, preventie- en bestrijdingsmogelijkheden van brand in rundvee-, varkens- en pluimveestallen. Afstudeeronderzoek Van Hall-Larenstein.

Peet, G.F.V. van der, R.W van der Meer, H. Docters van Leeuwen, S.R.M. van Wageningen-Lucardie, juni 2016. Monitoring integraal duurzame stallen. Wageningen Livestock Research, rapport 953. 


\section{Bijlage 1 Voortgangsrapportage Actieplan Stalbranden 2012-2017}
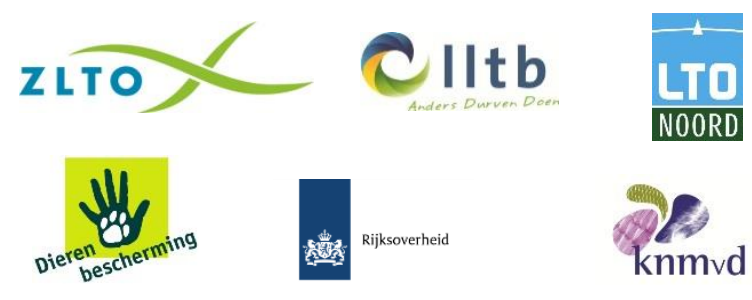

VIIIIJ VERBOND VAN VERZEKERAARS

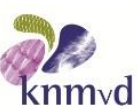

BRANDWEER

Nederland

\section{Voortgangsrapportage 2016 van de stuurgroep van het Actieplan Stalbranden 2012-2017}

\section{Actieplan stalbranden 2012-2017}

Het Actieplan loopt sinds 2012 en wordt in 2017 formeel afgerond. In 2012 zijn een aantal acties afgesproken. Door de samenwerking van de deelnemers aan het Actieplan is brandveiligheid van veestallen hoger op de agenda gekomen. Dat geldt voor de veehouders maar ook voor de adviseurs die op het erf komen. De voortgang van de verschillende actiepunten wordt beschreven. 2016 zou het laatste jaar zijn van het Actieplan 2012 - 2016. Besloten is om de duur van het Actieplan met een aantal maanden te verlengen tot medio 2017. Het Ministerie van Economische Zaken heeft Wageningen Universiteit en Research en het Instituut voor Fysieke Veiligheid gevraagd het Actieplan te evalueren. De evaluatie is inmiddels afgerond. In de evaluatie is beoordeeld of brandveiligheid in stallen is verbeterd en of het actieplan daar een bijdrage aan heeft geleverd. Partijen hebben de intentie uitgesproken om ook na afronden van het Actieplan te blijven samenwerken op het gebied van brandveiligheid van veestallen. Hoe en in welke vorm dat gebeurt krijgt in het najaar van 2017 verder vorm. In deze voortgangsrapportage worden alle punten uit het Actieplan genoemd. De punten B 4 en C1 en C6 zijn van toepassing op nieuwe stallen. De overige punten zijn zowel op bestaande als nieuwe stallen van toepassing.

\section{A) Activiteit; een brandveilige bedrijfsvoering.}

Doel: het vergroten en het verspreiden van parate kennis over hoe stalbranden kunnen worden voorkomen en hoe bij een eventuele brand de gevolgen kunnen worden beperkt.

\section{Voorgenomen actie; opschalen praktijknetwerken.}

Het praktijknetwerk voor varkens is opgeschaald naar rundvee en kippen. DLV heeft deze praktijknetwerken begeleid en uitgevoerd. Het Ministerie van EZ heeft deze praktijknetwerken mede gefinancierd. In deze praktijknetwerken hebben veehouders voor hun sector bekeken hoe ze de brandveiligheid op het bedrijf kunnen vergroten. Dat hebben ze gedaan voor het ontwerp van nieuwe stallen maar ook door te kijken hoe ze de brandveiligheid van bestaande stallen kunnen vergroten.

\section{Voorgenomen actie; 5-10 themabijeenkomsten per jaar.}

De volgende bijeenkomsten zijn sinds de start van het actieplan georganiseerd;

20 algemene bijeenkomsten

17 bijeenkomsten voor de rundveehouderij

4 bijeenkomsten voor de varkenshouders

4 bijeenkomsten voor de pluimveehouderij

1 bijeenkomsten voor de konijnenhouderij

2 bijeenkomsten voor de paardenhouderij 
De bijeenkomsten dragen er toe bij dat het bewustzijn van de veehouders wordt vergroot.

De bijeenkomsten worden door de deelnemers goed gewaardeerd. Het aantal deelnemers varieert tussen de 6 en de 75. Bij algemene ledenvergaderingen van LTO is de opkomst groter. Sommige bijeenkomsten worden sectorspecifiek (pluimvee, varkens en runderen) georganiseerd. De opkomst is dan kleiner omdat het hier om studieclubs gaat. Het voordeel van deze sectorspecifieke bijeenkomsten is dat er diepgaander op de desbetreffende sector ingegaan kan worden. Er wordt niet alleen gewezen op de risico's maar er wordt tevens in beeld gebracht welke maatregelen de sector kan nemen om brandveiligheid te bevorderen.

De afgelopen twee jaar zijn ook een aantal bijeenkomsten georganiseerd in het bredere kader van veiligheid op het erf. Deze bijeenkomsten worden op de boerderij zelf georganiseerd. Het Verbond van Verzekeraars en Brandweer Nederland verzorgen de lezingen op de informatiebijeenkomsten. Soms wordt STIGAS (Stichting voor gezond werken in de agrarische sector) ook bij de bijeenkomsten betrokken. Om het bewustzijn te vergroten worden sommige bijeenkomsten op het boerenerf georganiseerd. Dit leidt tot een beter begrip van de kritische factoren bij het ontstaan en de bestrijding van brand. LTO Nederland organiseert de bijeenkomsten.

De informatievoorziening richt zich niet alleen op de veehouders zelf maar ook op de erfbetreders. $\mathrm{Zij}$ komen regelmatig op het erf van de veehouders en hebben een relatief grote invloed op de bedrijfsvoering van de veehouders. Het gaat dan om adviseurs die boeren helpen met hun vergunning, vertegenwoordigers van voerleveranciers, stallenbouwers, dierenartsen en bedrijfseconomische adviseurs. In oktober 2013 is in Den Bosch een bijeenkomst voor erfbetreders gehouden. Er waren +/- 100 aanwezigen. De bijeenkomst is door de aanwezigen goed beoordeeld. In het najaar van 2016 is er een workshop voor de periferie georganiseerd in Hardenberg, daar waren $+/-30$ mensen aanwezig.

\section{Voorgenomen actie; $\mathbf{3}$ tot $\mathbf{5}$ nieuwsbrieven per jaar.}

Er wordt gebruik gemaakt van de reguliere informatiekanalen voor veehouders en erfbetreders. Het thema staat uitgediept op de websites van de drie regionale LTO's. Op deze websites staan onder andere tips en tools om de brandveiligheid te vergroten.

Over brandpreventie in stallen zijn de afgelopen jaren een groot aantal artikelen in de diverse agrarische media verschenen. In Nieuwe Oogst, de Boerderij maar ook in sectorspecifieke vakbladen zoals de Pluimveehouderij en de Kalverhouderij is de nodige aandacht aan het thema brandveiligheid besteed. De aanleiding voor de artikelen zijn divers; het starten van het Actieplan Stalbranden 2012 2016, het advies van de stuurgroep aan de Staatsecretaris over aanpassing van het Bouwbesluit, het voornemen tot aanpassing van de bouwregelgeving, het ingaan van de nieuwe bouwregelgeving en het introduceren van een speciale categorie voor brandveiligheid in de Maatlat Duurzame Veehouderij. Ook komen in een aantal artikelen ondernemers aan het woord die door brand getroffen zijn. In veel van deze artikelen staan tips en tools voor veehouders die het bewustzijn van de veehouder op het gebied van brandveiligheid vergroten. Ook bieden ze handelingsperspectief voor de veehouder.

Bijna elke stalbrand komt in de media. Vooral op sociale media en in de regionale kranten wordt daar aandacht aan besteed. Regelmatig wordt verwezen naar het Actieplan Stalbranden. Soms is er ook de ruimte om het Actieplan toe te lichten. De conclusie is dat informatie goed verspreid is maar nog niet altijd goed is geland. Het Actieplan heeft digitale posters ontwikkeld voor de varkenshouderij, pluimveehouderij en de melkveehouderij. In één oogopslag kunnen veehouders de belangrijkste risico's voor brandveiligheid op het erf zien.

Veehouders houden zich met vele onderwerpen bezig. De dagelijkse bedrijfsvoering en de economische resultaten staan voorop. Hoewel de gevolgen voor de dieren en de boer bij een brand groot zijn, heeft het thema brandveiligheid niet altijd de hoogste prioriteit. Daarom blijft het belangrijk bij herhaling te communiceren over het onderwerp. Bewustwording blijft ook in de toekomst een belangrijk onderwerp. 


\section{Voorgenomen actie; ontwikkelen onderwijsmodule brandveiligheid.}

Het blijkt niet eenvoudig om brandveiligheid opgenomen te krijgen in de reguliere onderwijsmodules van het agrarisch onderwijs. De onderwijsprogramma's zitten overvol. Door de informatiebijeenkomsten en de praktijknetwerken is er materiaal beschikbaar om een onderwijsmodule te maken. Onder andere op de middelbare agrarische school Prinsentuin in Breda moeten leerlingen een ondernemersplan schrijven. Eén van de aspecten die daarbij aan de orde komt is risicomanagement. Het Verbond van Verzekeraars verzorgt dit onderdeel waarbij brandveiligheid een themaonderdeel is. Ook is er op de onderwijsdag van de Uitvoeringsagenda Duurzame Veehouderij, bestemd voor onderwijzend personeel in het groene onderwijs, een workshop gegeven over risicomanagement.

\section{B) Activiteit; Brandveilige stallen voor mens en dier.}

Doel: Onderzoeken welke mogelijkheden er zijn om stallenbouw te verbeteren en de samenwerking tussen verschillende betrokkenen bij een brand te verbeteren.

\section{Voorgenomen actie; verbeteringsmogelijkheden samenwerking dierenarts en brandweer bij brand en diergedrag bij brand.}

De Koninklijke Nederlandse Maatschappij voor Dierengeneeskunde (KNMvD) is sinds 2015 betrokken bij het Actieplan Stalbranden en maakt deel uit van de werkgroep. In bijna alle gevallen is er een dierenarts bij een brand aanwezig. Een steeds vaker voorkomend fenomeen is dat door schaalvergroting en specialisatie in de diergeneeskundige zorg, dierenartsen op grotere afstand van hun klanten in de veehouderij wonen. De KNMvD heeft samen met Brandweer Nederland een handleiding voor dierenartsen gemaakt dat aangeeft, hoe in het geval de vaste dierenarts van een veehouder ver weg woont, er bij een brand, toch snel een dierenarts ter plaatse kan zijn.

De NVWA heeft ook een toezichthoudende taak voor dierenwelzijn. Zij maken sinds 2015 deel uit van de werkgroep. Na een brand zijn runderen, paarden en schapen nog vaak in veiligheid te brengen. Voor kippen, vleeskalveren en varkens is dat in de meeste gevallen onmogelijk. In opdracht van het Ministerie van Economische Zaken heeft er onderzoek plaatsgevonden naar euthanasie van dieren bij een stalbrand (WUR rapport 399; Welfare assessment of gas filled foam as an agent for killing poultry). Voor varkens en kalveren is dat mede vanwege de mestkelders onder de stal moeilijk toepasbaar. Voor kippen is dit bij dierziekten toe te passen maar bij brand biedt het geen oplossing omdat de dieren na de brand al door verstikking om het leven zijn gekomen.

\section{Voorgenomen actie; kennisniveau bij stallenbouwer, gemeente en veehouder over wet- en regelgeving vergroten.}

Via de ledenbijeenkomsten van LTO Nederland, artikelen in de diverse vakbladen en de bijeenkomsten voor de periferie, is het kennisniveau over regelgeving toegenomen. Voor vragen over de regelgeving kunnen veehouders en andere betrokkenen terecht bij de Helpdesk Bouwregelgeving van het Ministerie van Binnenlandse Zaken en Koninkrijkrelaties (BZK).

\section{Voorgenomen actie; onderzoek of het volgens Europees recht mogelijk is open verwarmingssystemen te verbieden.}

Open verwarmingsinstallaties in stallen vormen een risico op het ontstaan van brand. Na onderzoek is gebleken dat het in strijd is met het Europees recht om open verwarmingssystemen te verbieden. Daarom is gekozen om via voorlichting veehouders op het gevaar van deze toestellen te wijzen. Vakbladen zijn actief benaderd om hier aandacht aan te besteden. Het gebruik van open verwarmingssystemen komt nog het meeste voor in de pluimveehouderij. Gebaseerd op expert judgement kan geconstateerd worden dat het gebruik van open verwarmingssystemen afneemt. De systemen worden ook in bestaande stallen steeds vaker van een beveiliging tegen oververhitting voorzien. Bij modernere stallen worden ze niet of nauwelijks meer gebruikt. 


\section{Voorgenomen actie; Gelijkwaardigheid van brandveiligheid bij grotere brandcompartimenten $>2500 \mathrm{~m}^{2}$.}

Volgens het Bouwbesluit mogen er alleen brandcompartimenten (dat zijn ruimten die van elkaar afgescheiden zijn door een brandwerende scheiding van 30 of 60 minuten volgens het Bouwbesluit 2012) groter dan $2500 \mathrm{~m}^{2}$ gebouwd worden als kan worden aangetoond dat de brandveiligheid gelijkwaardig is aan die van een ruimte van $2500 \mathrm{~m}^{2}$. Er zijn verschillen tussen gemeenten hoe deze gelijkwaardigheid beoordeeld wordt. Het Nederlands Instituut voor Fysieke Veiligheid (NIFV) heeft in opdracht van het Ministerie van BZK onderzoek gedaan naar de gelijkwaardigheid van brand bij compartimenten groter dan $2500 \mathrm{~m}^{2}$. Het onderzoek gaat uit van een risicobenadering en is inmiddels afgerond. Het rapport "Risicovergelijking van stallen groter dan 2500m2" is te vinden op www.ifv.nl. Uit het onderzoek volgt dat door het toepassen van extra brandveiligheidsmaatregelen grote brandcompartimenten mogelijk zijn. Aansluitend hierop, mede op verzoek van het Actieplan Stalbranden, wordt er door het Nederlands Normalisatie Instituut een NEN-norm voor grotere brandcompartimenten ontwikkeld. NEN heeft in juni 2017 het normontwerp gepubliceerd ter commentaar. Publicatie van de definitieve norm is nog in 2017 voorzien. De bedoeling is dat deze NEN-norm wordt opgenomen in de bouwregelgeving. Bij bepaling van de NEN-norm is rekening gehouden met dierenleed. Ondanks de grotere brandveiligheid is een stalbrand nooit helemaal uit te sluiten.

\section{C) Activiteit; Stimuleren van brandveilige stallen.}

\section{Doel: Stimuleren van het gebruik van mogelijkheden die het optreden van stalbranden} kunnen voorkomen.

\section{Voorgenomen actie; er komt een aparte categorie voor brandveiligheid in de Maatlat Duurzame Veehouderij.}

Via fiscale maatregelen worden veehouders gestimuleerd duurzaam te investeren. Daarvoor is een instrument ontwikkeld; de Maatlat Duurzame Veehouderij (MDV). Op verschillende duurzaamheidscriteria (milieu, energie, dierenwelzijn, diergezondheid) moeten veehouders bovenwettelijk scoren om in aanmerking te komen voor fiscale voordelen. Sinds 1 januari 2014 is er een aparte categorie voor brandveiligheid opgenomen in de MDV. Willen veehouders in aanmerking komen voor fiscale voordelen, dan moeten ze ook bovenwettelijke maatregelen nemen op het gebied van brandveiligheid. In 2015 is het ambitieniveau van het onderdeel brandveiligheid in de MDV verhoogd. De meest voorkomende bovenwettelijke maatregelen waar veehouders in het kader van de MDV in geïnvesteerd hebben zijn:

- $\quad$ Het beveiligen van elektromotoren in dierverblijven tegen oververhitting;

- $\quad$ Opslagruimte voor brandbare voer- en strooiselmaterialen buiten brandcompartiment met dierverblijven situeren,

- $\quad$ Het 'open' uitvoeren van kabelgoten (tegen knaagdiervraat);

- Voldoende gekeurde brandblussers in de stal plaatsen;

- $\quad$ Een vaste noodstroomaggregaat in een aparte ruimte, afgescheiden van de technische ruimten;

- $\quad$ Specifiek bij melkvee: natuurlijk geventileerde stallen en tenminste twee toegangsdeuren.

Het opnemen van maatregelen in de MDV levert nieuwe innovaties op. Sommige van deze innovaties zijn alleen geschikt voor nieuwe stallen, anderen kunnen ook in bestaande stallen toegepast worden.

Voor Brabantse bedrijven geldt de Brabantse Zorgvuldigheidsscore (BZV). Als bedrijven een bouwvergunning nodig hebben moeten ze voldoen aan de BZV. Bedrijven zijn verplicht bovenwettelijke maatregelen te nemen, maar ze hebben de keuzevrijheid, welke maatregelen ze kiezen. Ze kunnen ook scoren op het thema brandveiligheid. De BZV geldt zowel voor nieuwe als bestaande stallen. 


\section{Voorgenomen actie; periodieke keuringen regelen via kwaliteitssystemen.}

Het Actieplan Stalbranden constateert dat verzekeraars steeds vaker periodieke controle van de elektrische installatie eisen (z.g. Agro Elektra Inspectie). Bijna alle verzekeraars vragen aan de grotere intensieve veehouderijbedrijven deze periodieke keuring.

In 2015 heeft het Actieplan Stalbranden aan IKB Varken gevraagd om deze verplichting op te nemen in IKB. Voorlopig volstaat IKB echter met voorlichting over de Agro Elektra Inspectie. Eind 2016 is er namens het Actieplan Stalbranden opnieuw een brief gestuurd naar de diverse kwaliteitssystemen om de Agro Electra Inspectie op te nemen in hun systeem. De Dierenbescherming neemt de Agro Elektra Inspectie op in de criteria van haar Beter Leven keurmerk op. IKB Kip en IKB Ei hebben de intentie uitgesproken om de keuringen op te nemen in hun kwaliteitssystemen. De procedure voor opname loopt nu. Bij kalveren en varkens hebben de vertegenwoordigers van de primaire sector aangegeven dat ze de keuringen op willen nemen in hun kwaliteitssystemen. De procedure moet nog worden opgestart en de goedkeuring krijgen van andere partijen die betrokken zijn bij deze kwaliteitssystemen.

\section{Voorgenomen actie; bandveiligheid onderdeel maken van een integrale handhavingsstrategie.}

$\mathrm{Er}$ is contact geweest met twee omgevingsdiensten in regio's waar veel intensieve veehouderij voorkomt; te weten in Brabant Noord Oost en in de Gelderse Vallei. We hebben de omgevingsdiensten gevraagd of ze bij handhaving ook willen letten op brandveiligheid.

Normaliter controleert de gemeente de brandveiligheid vooral bij de oplevering van de bouw. Het blijkt in de praktijk niet mogelijk om brandveiligheid onderdeel uit te laten maken van reguliere handhavingstrajecten. Kanttekening blijft, medeafhankelijk van de regio en de grootte van het veehouderijbedrijf, dat omgevingsdiensten slechts één 1 keer in de 5 tot 10 jaar langskomen op een veehouderijbedrijf.

\section{Voorgenomen actie; stimuleren van innovatie van detectiesystemen.}

Het Actieplan Stalbranden is aanspeekpunt voor nieuwe innovaties. Bedrijven met nieuwe innovaties kunnen zich melden. Waar mogelijk proberen we ze in contact te brengen met relevante stakeholders om de innovatie verder te brengen, op hun uitvoerbaarheid te laten beoordelen, of deze in de praktijk te laten testen.

Er zijn al nieuwe detectiesystemen op de markt gebracht, ze worden gestimuleerd via de Maatlat Duurzame Veehouderij. Probleem tot nu toe is de storingsgevoeligheid. Dit komt doordat het stalklimaat vaak redelijk agressief is. Nieuw is de ontwikkeling van detectoren met verificatie. Deze detectiesystemen kunnen zelf rook van stof onderscheiden en zo vals alarm vanwege stof voorkomen. De inschatting is dat er nog een paar jaar nodig is om deze systemen praktijkrijp te maken.

Bij paarden is er een detectiesysteem ontwikkeld dat detectie combineert met het automatisch openen van de paardenboxen en de staldeuren. Dit is ook in de praktijk samen met de brandweer uitgetest en positief beoordeeld. Bij varkens is een watervernevelingsinstallatie uitgetest op het varkensproefbedrijf in Sterksel. Dit systeem is al op de markt maar nog niet helemaal praktijkrijp.

\section{Voorgenomen actie; eenduidiger beleid bij gemeenten.}

Het beleid van gemeenten ten aanzien van brandveiligheid in stallen verschilt nog wel eens. Verschillen doen zich vooral voor in het beleid ten aanzien van stallen met brandcompartimenten groter dan 2500 m2 (zie onder B4). Door de vorming van Brandweer Nederland in 25 veiligheidsregio's is het beleid al eenduidiger geworden. Als er een landelijke NEN-norm is voor deze grotere brandcompartimenten is dit probleem grotendeels opgelost. 


\section{Voorgenomen actie; aanpassen en implementeren regelgeving.}

Per 1 april 2014 is de bouwregelgeving aangepast. Dierenverblijven zijn een aparte subcategorie in het Bouwbesluit geworden. Voor deze subcategorie is het verplicht om de technische ruimte 60 minuten brandwerend te maken en moeten isolatie- en aankledingsmateriaal minimaal van brandklasse B kwaliteit zijn. In een range van A tot en met D staat Brandklasse B voor 'moeilijk brandbaar en erg beperkte bijdrage'. In 2015 heeft het IFV in opdracht van het ministerie van BZK onderzocht hoe de nieuwe voorschriften door de bouwpraktijk zijn opgepakt. De bevindingen hiervan (rapport 15 december 2015, te vinden op www.ifv.nl) zijn meegenomen in de eindevaluatie door WUR/IFV.

\section{D) Activiteit; verbeteren inzicht in de oorzaken en beheersbaarheid van stalbranden.}

\section{Doel: het verzamelen en inventariseren van gegevens die een beter inzicht kunnen geven in het voorkomen van stalbranden en de effectiviteit van de reeds genomen matregelen.}

\section{Voorgenomen actie; betere registratie van stalbranden}

Sinds 2014 werken Brandweer Nederland en het Verbond van Verzekeraars samen om stalbranden te registreren. Brandweer Nederland registreert sindsdien iedere stalbrand. Deze cijfers worden vergeleken met de cijfers van het Verbond van Verzekeraars. In 2012 en 2013 registreerden de Brandweerkorpsen nog niet alle stalbranden. De cijfers voor 2012 en 2013 zijn daarom door het Verbond van Verzekeraars geïnventariseerd. Zij hebben een extra inspanning geleverd om de cijfers van 2012 en 2013 boven water te krijgen. De cijfers voor 2012 en 2013 zijn redelijk betrouwbaar maar niet 100\% dekkend. De cijfers voor 2014, 2015 en 2016 zijn verzameld in een coproductie tussen Brandweer Nederland en het Verbond van Verzekeraars.

\begin{tabular}{|c|c|c|c|c|c|c|c|c|c|c|}
\hline & $\begin{array}{l}\text { Aantal } \\
\text { stallen } \\
2012\end{array}$ & $\begin{array}{l}\text { Aantal } \\
\text { dieren } \\
2012\end{array}$ & $\begin{array}{l}\text { Aantal } \\
\text { stallen } \\
2013\end{array}$ & $\begin{array}{l}\text { Aantal } \\
\text { dieren } \\
2013\end{array}$ & $\begin{array}{l}\text { Aantal } \\
\text { Stallen } \\
2014\end{array}$ & $\begin{array}{l}\text { Aantal } \\
\text { Dieren } \\
2014\end{array}$ & $\begin{array}{l}\text { Aantal } \\
\text { stallen } \\
2015\end{array}$ & $\begin{array}{l}\text { Aantal } \\
\text { dieren } \\
2015\end{array}$ & $\begin{array}{l}\text { Aantal } \\
\text { stallen } \\
2016\end{array}$ & $\begin{array}{l}\text { Aantal } \\
\text { dieren } \\
2016\end{array}$ \\
\hline Varkens & 6 & 4.600 & 9 & 7.781 & 6 & 5.770 & 5 & 4.105 & 8 & 13.592 \\
\hline Pluimvee & 4 & 86.030 & 5 & 17.000 & 5 & 32.000 & 3 & 129.000 & 8 & 185.000 \\
\hline Kalveren & 1 & 3 & 4 & 515 & 3 & 0 & 7 & 86 & 10 & 418 \\
\hline $\begin{array}{l}\text { Overige } \\
\text { rundvee }\end{array}$ & 4 & 1 & 5 & 4 & 14 & 33 & 11 & 9 & 9 & 41 \\
\hline Paarden & 6 & 20 & 1 & 0 & 0 & 0 & 3 & 1 & 6 & 12 \\
\hline $\begin{array}{l}\text { Schapen } \\
\text { geiten }\end{array}$ & - & - & 2 & 2 & 1 & 600 & 2 & 0 & 4 & 11 \\
\hline Konijnen & & & & & & & & & 1 & 3000 \\
\hline onbekend & & & & & & & & & 1 & 0 \\
\hline Totaal & 21 & 90.634 & 26 & 25302 & 29 & 38.333 & 31 & 133.101 & 47 & 202.074 \\
\hline
\end{tabular}

- $\quad$ Een enkele brand kan het aantal in een jaar bij branden betrokken dieren sterk beïnvloeden. Zo was er in 2013 een brand in een varkensstal met 6000 dierlijke slachtoffers. In 2016 kwamen er bij één stalbrand 9000 varkens om. Ook kwamen er in 2016 bij een brand in een kippenstal 60.000 dieren om. Het is dan ook nog te vroeg om een trend in de cijfers te ontdekken.

- $\quad$ Bij rundveebedrijven worden de dieren vaak gered. De vuurlast is lager en dieren zijn vaak al gewend om naar buiten te gaan. Bij varkens en bij pluimvee is evacuatie nauwelijks mogelijk. Het fysieke houderijsysteem is minder geschikt om dieren te redden

\section{Voorgenomen actie; onderzoek naar oorzaken van stalbranden.}

In het verleden werden stalbranden niet altijd onderzocht. Inmiddels is geregeld dat vanaf 2014 bij alle stalbranden waarbij dieren omkomen onderzocht wordt wat de oorzaak was van de ontstane brand. 
De belangrijkste oorzaak voor brand is kortsluiting in de elektra. Dat geldt in het bijzonder voor de varkens- en de kippenstallen. Werkzaamheden in de stal, zoals lassen en slijpen, zijn ook regelmatig oorzaak van stalbranden. Defecte apparaten en hooibroei veroorzaken ook regelmatig brand maar leiden meestal niet tot veel dierlijke slachtoffers. Dit beeld van de oorzaken van stalbranden wijkt niet af van het oorspronkelijke beeld toen er in 2012 gestart werd met het Actieplan. 


\section{Bijlage 2 Vragenlijst interviews}

\section{Opzet vragenlijst interviews Evaluatie Actieplan Stalbranden}

Organisatie en naam geïnterviewde:

Functie: .....

Datum interview:

Interviewers:

> S.v.p. apart beantwoorden voor respectievelijk bestaande stallen en voor nieuw- en verbouw van stallen vergund na 1-4-2014 (de inwerkingtreding van het nieuwe Bouwbesluit).

> Waar relevant verschillen tussen sectoren aangeven of aangeven voor welke sector een antwoord specifiek geldt (focus: melkvee, varkens, pluimvee, vleeskalveren).

ONTSTAAN VAN BRAND

1. In de huidige praktijksituatie voor resp. bestaande stallen-nieuwbouw-verbouw:

a. Wat denkt u van de kans op het ontstaan van brand in deze stallen? Zijn daar veranderingen in opgetreden ten opzichte van 4 jaar geleden?

i. in relatie met elektriciteit/kortsluiting (bedrading, apparatuur)?

ii. in relatie met zelfontbranding/oververhitting van apparatuur en machines (en de plaats van stalling daarvan)?

iii. in relatie met brandveilig werken (lassen, slijpen, dakdekken, afvalverbranden, ...)?

b. Waar ziet u mogelijkheden om de kans op het ontstaan van brand in resp. bestaande stallen-nieuwbouw-verbouw verder te reduceren? Op welke manier zou dat kunnen worden ondersteund/aangepakt (inzet regelgeving-educatie-sociale drukeconomische prikkels-tools (publiek of privaat)?

\section{SNELLE DETECTIE}

2. In de huidige praktijksituatie voor resp. bestaande stallen-nieuwbouw-verbouw:

a. Welke ontwikkelingen heeft u gezien in toepassing van branddetectiesystemen (automatische systemen/detectie door personen, ...)? Is dit anders dan 4 jaar geleden?

3. Kan een snelle branddetectie in stallen verder worden bevorderd (werkbaarheid detectiesysteem; toepassing in praktijk) volgens u en zo ja, hoe? Hoe kunnen gewenste ontwikkelingen m.b.t. snelle branddetectie worden ondersteund, wat is daarvoor nodig?

\section{BEPERKING BRANDUITBREIDING}

4. In de huidige praktijksituatie voor resp. bestaande stallen-nieuwbouw-verbouw:

a. Hoe zit het met de kans op een snelle uitbreiding van brand in en tussen veestallen? Waar hangt dit mee samen (o.a. brandklassen van materialen in stal; (hokinrichting/aankleding/isolatie; vlottende materialen zoals strooisel; ..) compartimentering); afstanden tussen stallen, indeling van het terrein? Is dit bij recent gerealiseerde stallen anders dan 4 jaar geleden? Ziet u daarbij verschillen tussen sectoren? Als u verschillen ervaart; Wat is daarbij behulpzaam en wat is remmend geweest (bv regelgeving, verzekeraars, de veehouder, uw advies, kosten, ...) ?

5. Kan de snelheid van branduitbreiding in en tussen stallen verder worden beperkt volgens $u$ en zo ja, hoe? Hoe kunnen gewenste ontwikkelingen worden ondersteund, welk instrumentarium inzetten?

\section{BLUSSEN VAN (LOKALE) BRANDEN}

6. In de huidige praktijksituatie voor resp. bestaande stallen-nieuwbouw-verbouw:

a. Zijn er goede mogelijkheden voor het blussen van lokale branden? Welke ontwikkelingen en ook welke beperkingen ziet u hierin (automatische blussystemen; handmatige blusvoorzieningen, ...)? Is dit anders dan 4 jaar geleden?

7. Kan de kans op het blussen door veehouders/personeel van lokale branden in stallen verder worden bevorderd volgens u en zo ja, hoe? Hoe kunnen gewenste ontwikkelingen worden 
ondersteund, welk instrumentarium inzetten? (lokale brand = nog beperkt in omvang, bv. in apparaat, nog niet in hele ruimte)

8. Zijn er ontwikkelingen geweest in het toepassen van (automatische) rook-warmteafvoer (RWA)? Hoe kunnen gewenste ontwikkelingen hierin verder worden bevorderd?

\section{EVACUEREN VAN DIEREN}

9. In de huidige praktijksituatie voor resp. bestaande stallen-nieuwbouw-verbouw:

a. Zijn de kansen op evacuatie van dieren bij stalbrand in specifieke veehouderijsectoren veranderd ten opzichte van 4 jaar gelden? Waar zit dat in?

b. Ziet u mogelijkheden om de mogelijkheden tot evacuatie van dieren bij stalbrand verder te bevorderen en zo ja, hoe? Hoe kunnen gewenste ontwikkelingen worden ondersteund?

10. Zijn de mogelijkheden voor een snelle euthanasering van niet te redden dieren in de stal tijdens een stalbrand volgens $u$ veranderd in de afgelopen 4 jaren? Ziet u mogelijkheden voor (verdere) verbetering?

\section{HOUDINGSVERANDERING}

11. Ziet u de laatste jaren een houdingsverandering:

a. bij gemeenten resp. brandweer resp. veehouders resp. aannemers resp. installateurs m.b.t. brandveiligheid bij nieuwbouw, renovatie en/of vervanging van inrichting/apparatuur?

b. bij veehouders en stalinrichters /installateurs m.b.t. brandveilig werken bij risicovolle werkzaamheden zoals lassen, slijpen, stallen van zelfontbrandbare machines, ...?

\section{TOEKOMSTIGE ONTWIKKELINGEN IN DE VEEHOUDERIJ}

12. Verwacht $u$, of voorziet $u$ toekomstige ontwikkelingen in de veehouderijsectoren (huisvestingssystemen) en/of stallenbouw die van invloed zullen zijn op de brandveiligheid?

a. Zo ja, welke?

b. Welke actie vragen deze ontwikkelingen in relatie met brandveiligheid?

\section{TOT SLOT}

13. Vindt u de overall kans op brand in veestallen met dierlijke slachtoffers toe- of afgenomen in de afgelopen jaren?

14. Welke rol heeft het Actieplan Stalbranden daar volgens $u$ in gespeeld?

15. Welke aanvullende acties vindt u van belang? [Voor resp. bestaande stallen en/of bij nieuw-/ verbouw]

\section{HARTELIJK DANK VOOR UW MEDEWERKING!}




\section{Bijlage 3 Vragenlijst internetenquête veehouders}

\section{Inleiding}

In 2012 heeft een onderzoek plaatsgevonden naar brandrisico's en brandveiligheid van stallen door het Instituut Fysieke Veiligheid en Wageningen Livestock Research. Op dit ogenblik herhalen wij dit onderzoek om na te gaan of er veranderingen zijn opgetreden in het beperken van risico's op brand in stallen. Graag willen wij u dan ook een aantal vragen hierover stellen.

Het invullen van de vragenlijst duurt ongeveer 5 minuten. De door $u$ ingevulde antwoorden zijn anoniem. Mochten er vragen en/of opmerkingen zijn, neem dan gerust contact op met charlotte.vanruijven@ifv.nl

\section{Pagina 1: Algemene informatie}

Wat voor soort bedrijf heeft u?
a. Pluimvee
b. Varkens
c. Runderen
d. Overig

Hoeveel dieren heeft $\mathrm{u}$ ?

Heeft $\mathrm{u}$ een brand gehad in uw stallen?
a. Ja
b. Nee
Indien ja;
Wanneer? (Jaartal)

Pagina 2: Brandrisico's en brandveiligheid stallen

2. Voert u zelf (of uw personeel) werkzaamheden uit aan de elektrische installatie in uw stallen?

a. Ja

b. Nee

3. Is de elektrische installatie in de afgelopen twee jaar gekeurd?
a. Ja
b. Nee

4. Zijn de elektrische installatie en de onderdelen daarvan vrij van stofophoping?

a. Ja
b. Nee

5. Voert u zelf (of uw personeel) las- en slijpwerkzaamheden uit in de stal?

a. Ja

b. Nee

Indien ja (Ja/nee),

a. Heeft u daarbij een goedgekeurde brandblusser van ten minste $5 \mathrm{~kg}$ voor direct gebruik bij de hand?

a. Ja

b. Heeft u daarbij een blusdeken voor direct gebruik bij de hand?

a. Ja

b. Nee

c. Heeft u brandbare stoffen tot op een veilige afstand van de plaats van de werkzaamheden verwijderd? Of, indien dit niet mogelijk is, heeft u gezorgd voor brandwerende bescherming ervan?

a. Ja

b. Nee

d. Dekt u de roostervloer in de nabijheid van de plaats van werkzaamheden brandwerend af?
a. Ja
b. Nee

e. Controleert u daarna of er niets smeult of kan gaan smeulen?

a. Ja

b. Nee 


\section{Pagina 3: Brandrisico's en brandveiligheid stallen}

6. Stalt u machines zoals tractoren, shoveltjes en grasmaaiers in de stal die daar niet noodzakelijk hoeven te staan?
a. Ja

b. Nee

7. Gebruikt u open verbrandingssystemen zoals gasheaters en warmtekanonnen?
a. Ja
b. Nee

8. Zijn de elektromotoren die in de stalruimtes aanwezig zijn beveiligd tegen oververhitting?

a. Ja

b. Nee

9. Verbrandt u wel eens afval nabij de stal?

a. Ja

b. Nee

10. Heeft u goedgekeurde brandblussers in of nabij de stal?
a. Ja
b. Nee

\section{Pagina 4: Brandrisico's en brandveiligheid stallen}

11. Controleert u regelmatig of er geen potentiële brandoorzaken in uw stal zijn, zoals stofvorming of broei?
a. Ja
b. Nee

12. Geldt bij u een rookverbod in de stal?
a. Ja
b. Nee

13. Indien u personeel heeft: instrueert u uw personeel over brandrisico's en brandveilig werken?

a. Ja

b. Nee

c. Ik heb geen personeel

Pagina 5: Brandrisico's en brandveiligheid stallen

14. Bent $u$ bekend met het feit dat er een Actieplan stalbranden is ?

a. Ja

b. Nee

Indien ja;

a. Ik heb daarover gelezen in de vakpers

b. Ik heb daarover gehoord van collega's

c. Ik ben bij een bijeenkomst geweest waarin dit inhoudelijk is besproken

d. Anders, namelijk

Hartelijk dank voor uw medewerking! 


\section{Bijlage 4 Resultaten internetenquête veehouders}

Antwoorden van veehouders (horizontale as = aantal respondenten) op vragen in de internetenquête.

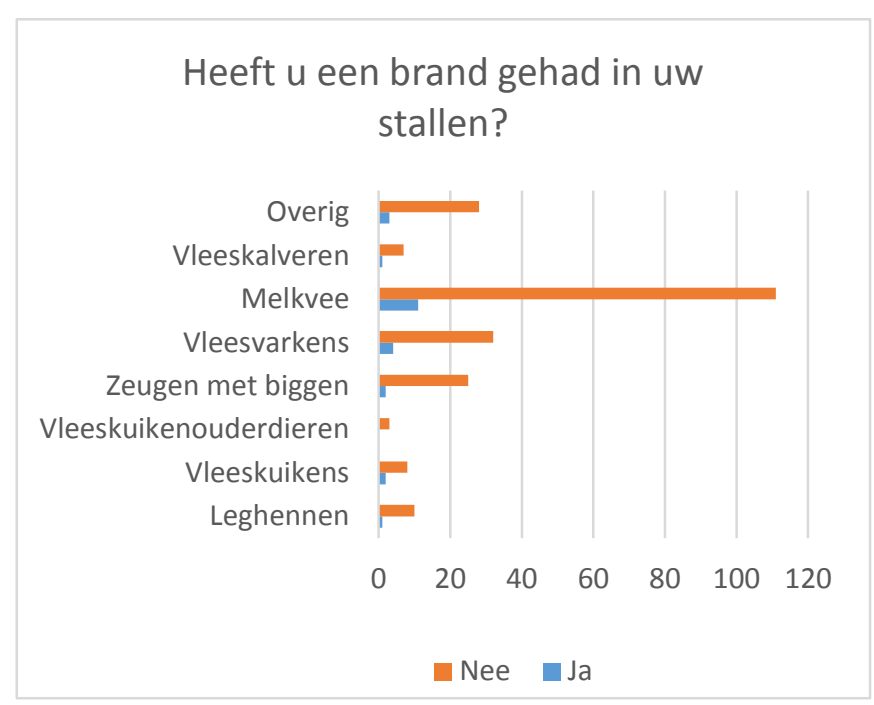

Figuur a

Figuur c Blusdeken bij las- en slijpwerkzaamheden

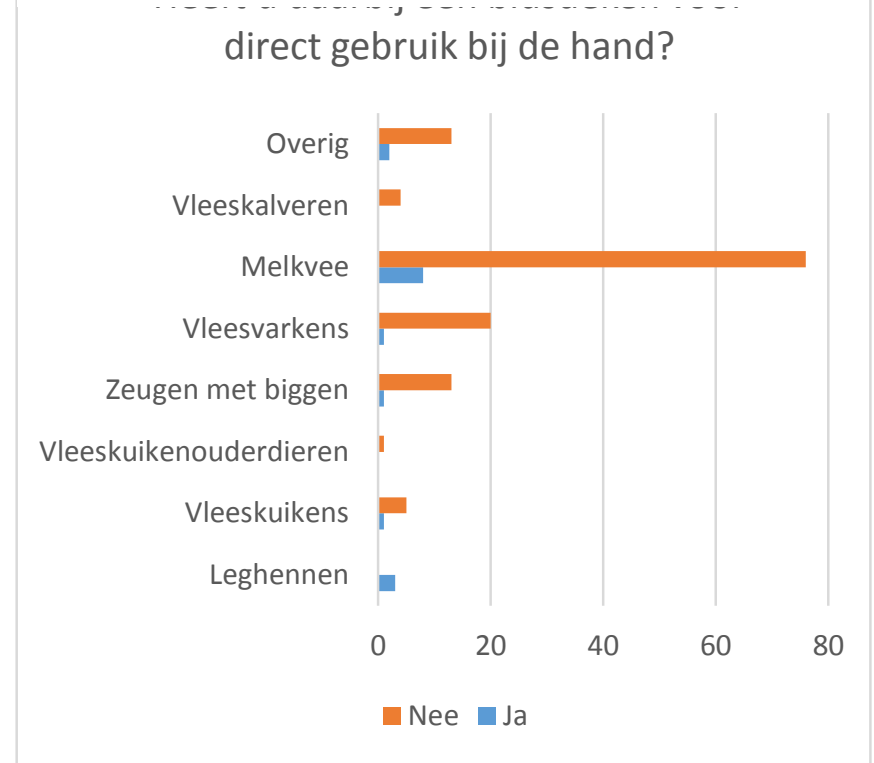

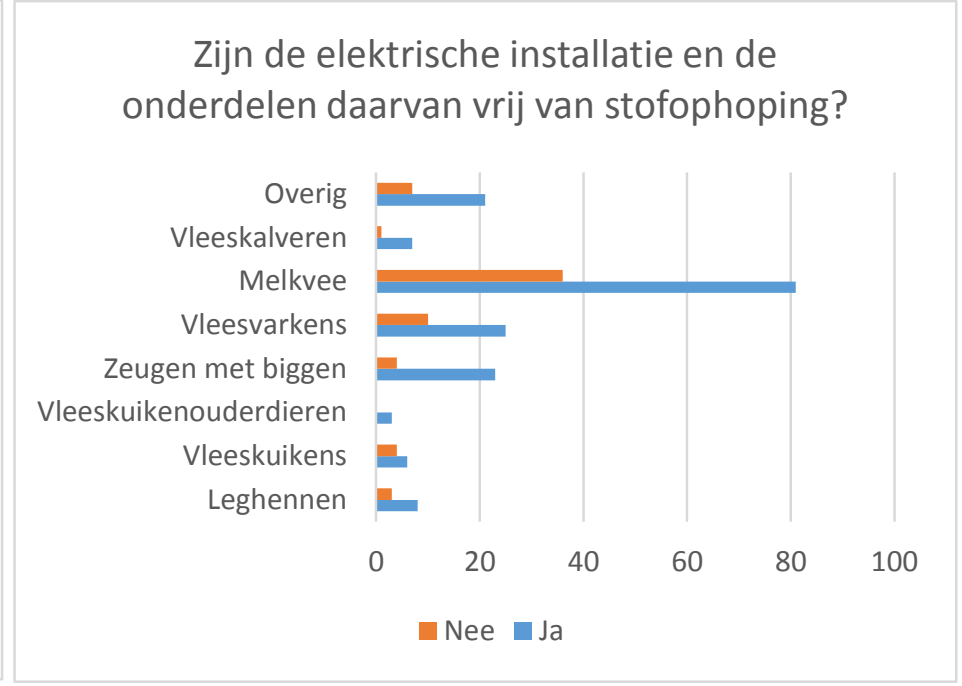

Figuur b Elektrische installaties en onderdelen vrij van stofophoping

Figuur d Brandbare stoffen op afstand bij werkzaamheden in de stal 


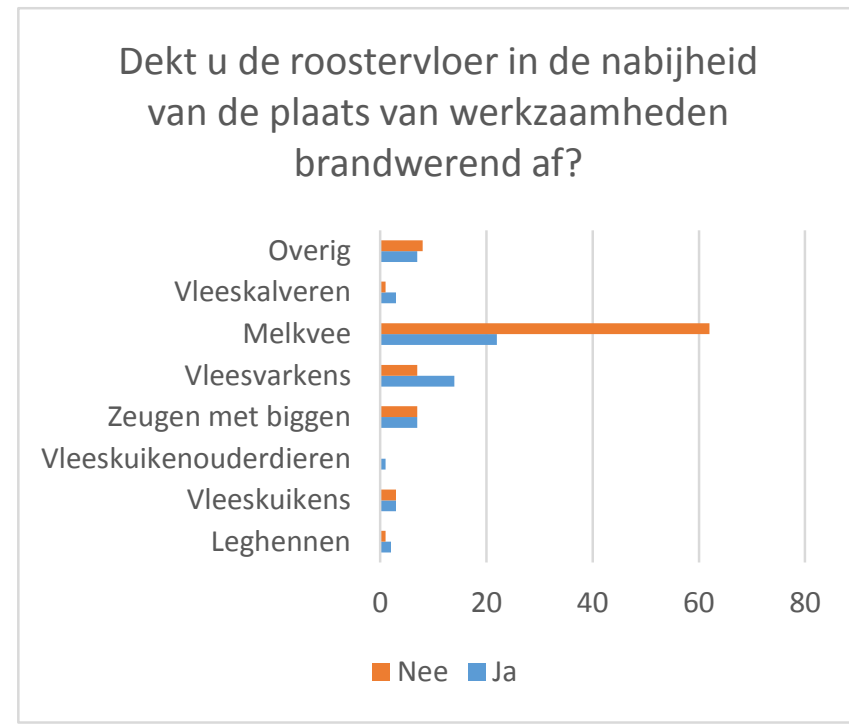

Figuur e Afdekken roostervloer bij werkzaamheden

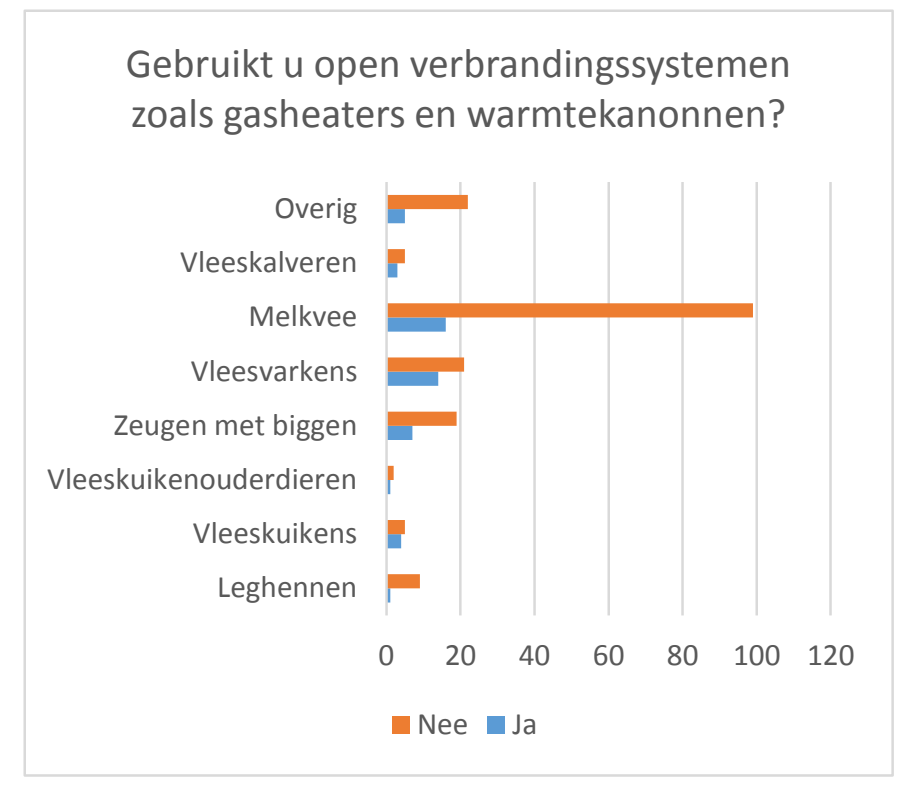

Controleert u daarna of er niets smeult of kan gaan smeulen?

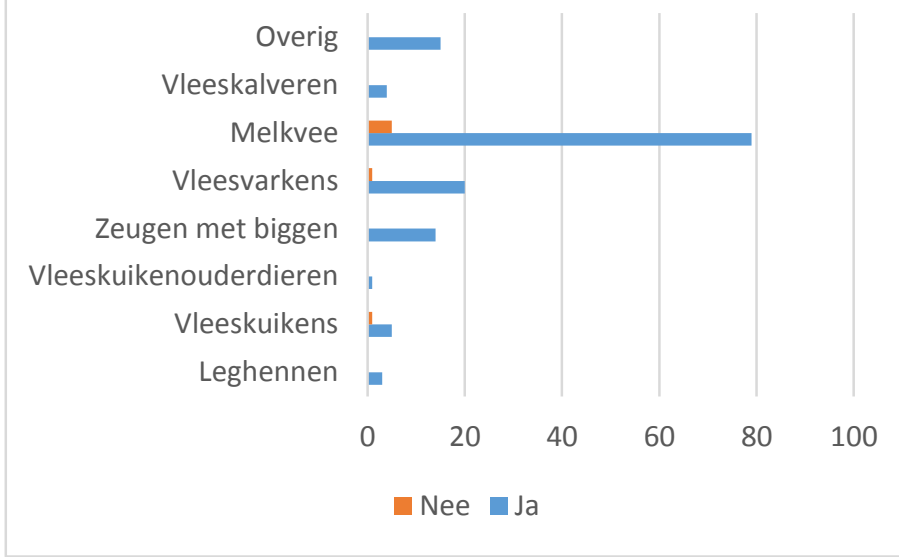

Figuur f Afdekken roostervloer bij werkzaamheden

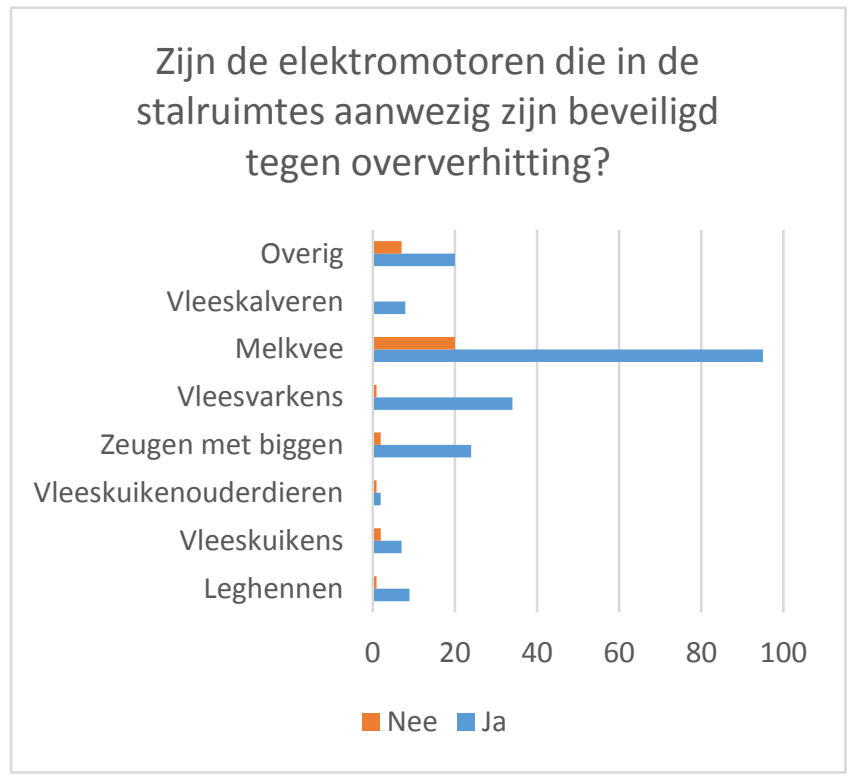

Figuur g Gebruik open-vuur verbrandingssystemen in stallen Figuur h Beveiliging elektromotoren tegen oververhitting

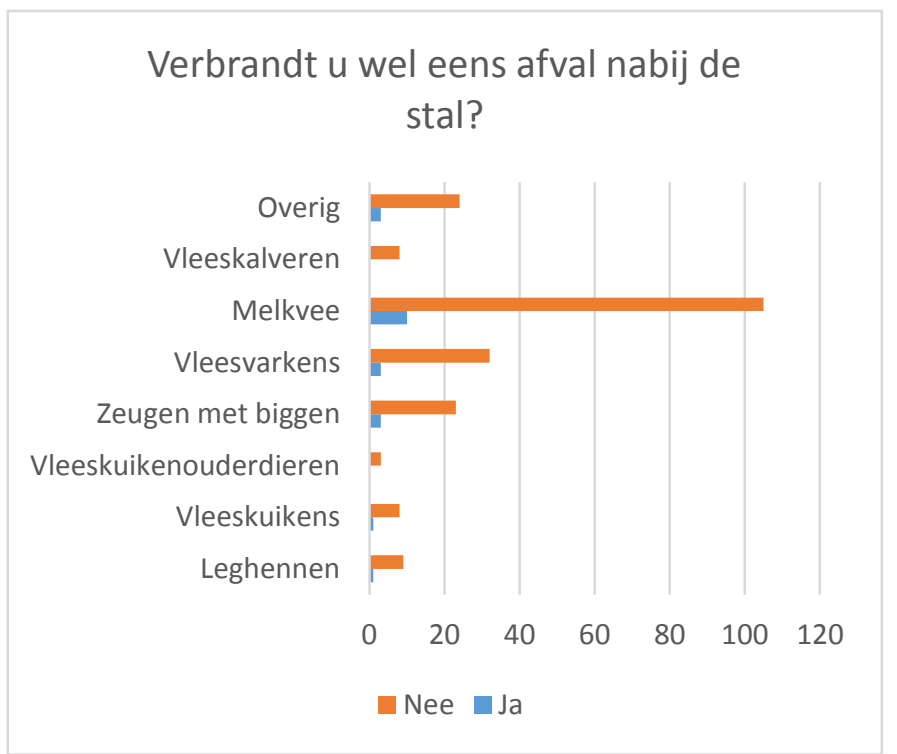

Figuur i Afvalverbranding bij stal

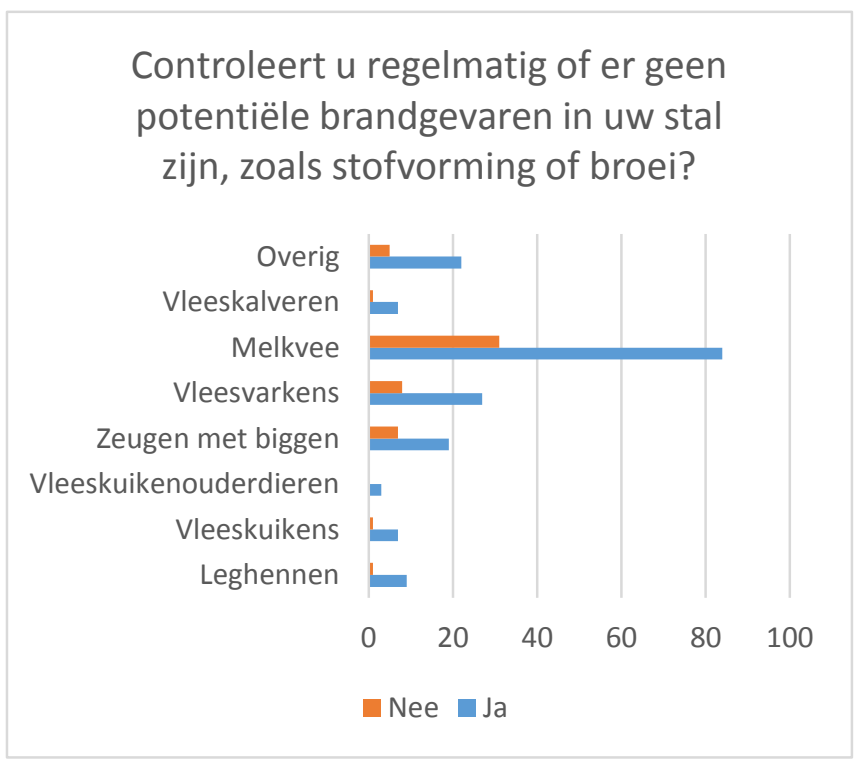

Figuur $j$ Controle op potentiele brandgevaren 


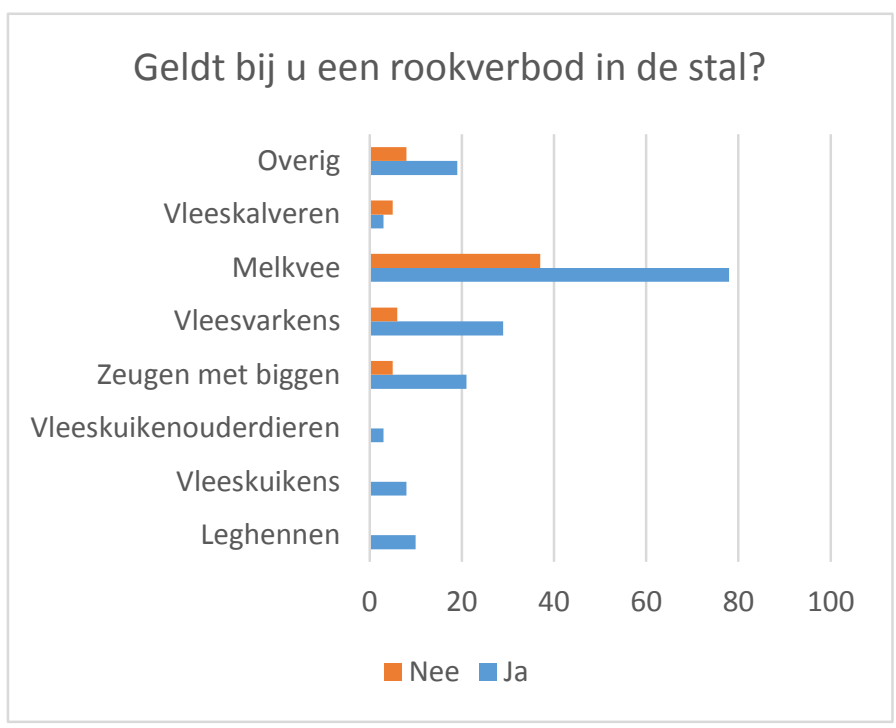

Figuur $k$ Controle op potentiele brandgevaren

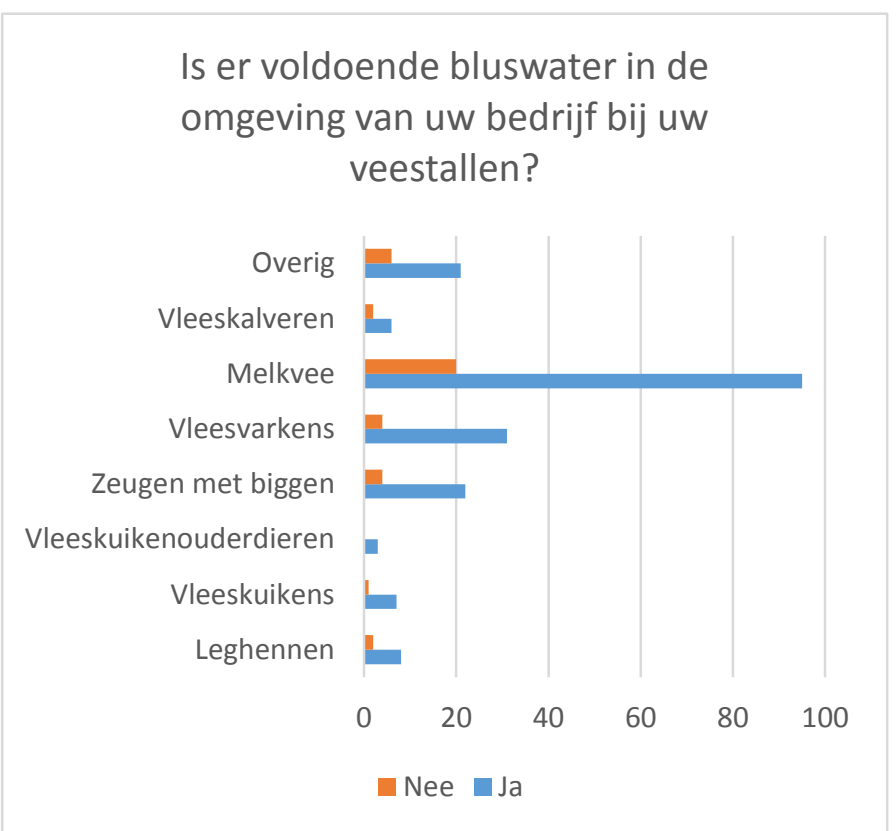

Figuur m Aanwezigheid voldoende bluswater

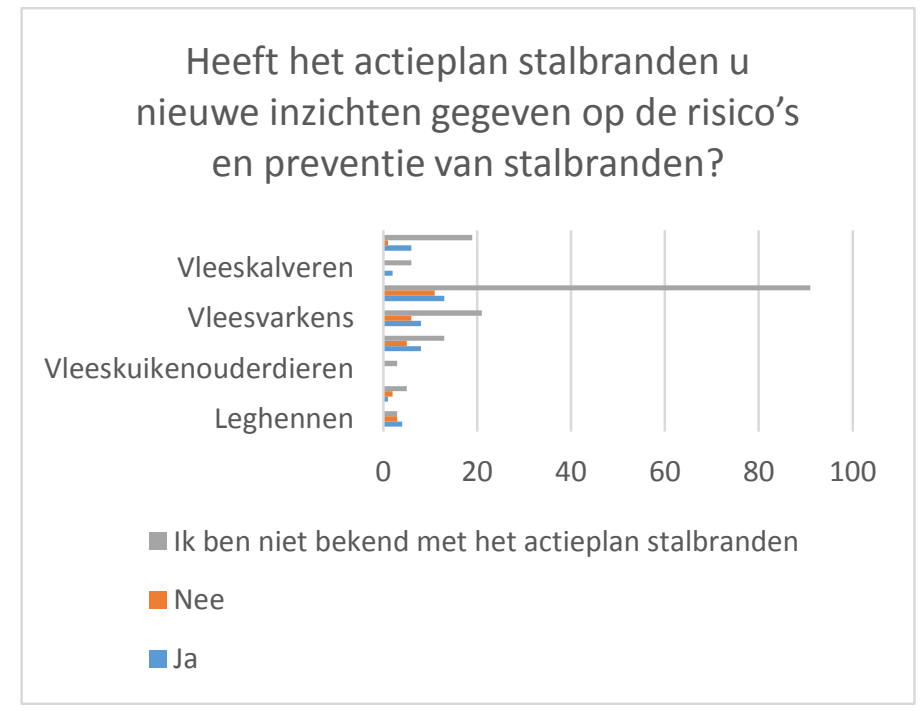

Figuur o Actieplan en nieuwe inzichten [grijs = niet bekend met Actieplan]
Indien u personeel heeft: instrueert u uw personeel over brandrisico's en brandveilig werken

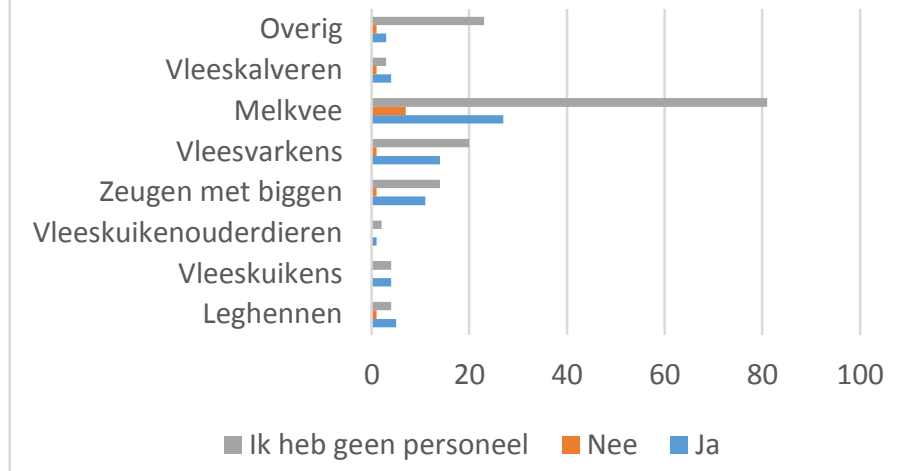

Figuur / Instructie personeel (grijs= geen personeel)

Bent $\mathrm{u}$ bekend met de inhoud van het Actieplan?

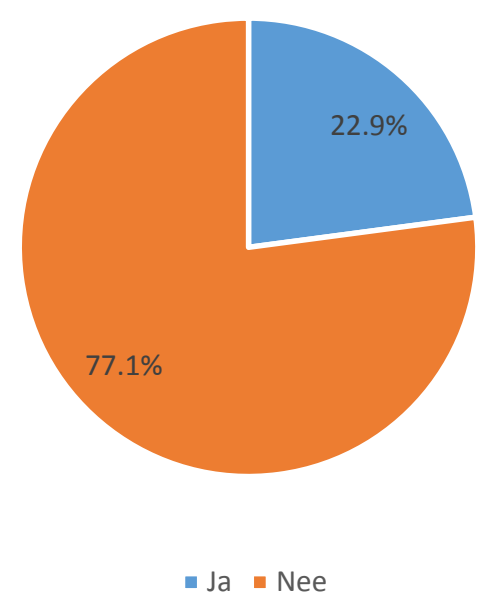

Figuur n Bekend met inhoud Actieplan

$U$ heeft aangegeven bekend te zijn met het actieplan stalbranden. Hoe bent $u$ aan kennis over dit actieplan gekomen?

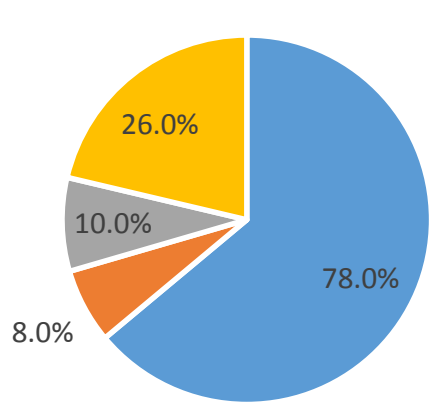

- Ik heb daarover gelezen in de vakpers

- Ik heb daarover gehoord van collega's

- Ik ben bij een bijeenkomst geweest waarin dit inhoudelijk is besproken - Anders, namelijk 


\section{Bijlage 5 Sectorspecifieke ontwikkelingen}

\section{Melkveehouderij}

Vanaf 2010 zijn veel nieuwbouw en uitbreidingen gerealiseerd in aanloop naar het wegvallen van het melkquotum. De grote spurt in renovatie/uitbreiding en bouw van nieuwe melkveestallen is achter de rug. De verwachting is dat er de komende jaren een forse sanering zal gaan plaatsvinden in de melkveehouderij met een versnelde uitfasering van bedrijven zonder opvolgers.

Onder invloed van de ammoniakregelgeving zien we in de melkveesector een ontwikkeling naar dichte emissiearme vloeren in de stal met mestopslag of snelle mestbewerking (monovergisting) buiten de stal. Gevolg hiervan is dat er minder risico is op brandbare gassen in de stal. Daarnaast zien we in bestaande stallen steeds vaker het probleem van schuimvorming op het mestoppervlak optreden, met risico's van dien. Diverse (grotere) bedrijven kiezen voor een luchtwasser om de emissie van ammoniak te reduceren. Daarmee is een stap gezet naar mechanische ventilatie van melkveestallen. Dit geeft echter nog wel de nodige onzekerheden.

Een andere ontwikkeling is de toenemende mate van automatisering in de stal. Denk hierbij aan mestrobotjes, voeraanschuifrobotjes, volautomatische ruwvoerdoseersystemen e.d. Automatische melksystemen nemen niet verder in aandeel toe. Markt hiervoor lijkt in Nederland gericht op gezinsbedrijven (bedrijven tot 200 melkkoeien). Genoemde automatisering is door de hele stal heen te vinden en laat zich lastig concentreren in een technische ruimte.

Door de groei van de bedrijven en de daarmee samenhangende toename van de grootte van stallen, zijn deze zeer ruim van opzet en toegankelijk voor tractoren en zwaar verkeer. Dit kan een risico vormen als de veehouder zich niet bewust is van risico's ten aanzien van zelfontbranding. Het gebruik van stro neemt wat toe door toepassing van transitieruimtes en aparte strohokken voor zieke en kalvende dieren. Hier is aandacht nodig voor de plaats van opslag van het stro.

Een aantal jaren geleden is een ontwikkeling op gang gekomen richting vrijloopstallen. Stallen waarin de dieren vrij kunnen bewegen in een ruimte voorzien van een dik bed met strooiselmateriaal. De verdere ontwikkeling van deze vorm van huisvesting staat stil. Onder andere vanwege discussie over de kwaliteit van de melk (kiemgetal) en emissies (ammoniak, lachgas) uit het ligbed.

\section{Vleeskalverhouderij}

In de vleeskalverhouderij heeft in de afgelopen jaren een flinke schaalvergroting plaatsgevonden. Het lijkt er nog niet direct op dat deze ontwikkeling nu is afgelopen. Binnen de fosfaatregeling voor rundvee zijn de vleeskalverbedrijven vooralsnog gevrijwaard van enige vorm van productierechten. Bij de blankvleesproductie en opfok rosé wordt toegewerkt naar volledige bedrijfs all-in all out. Nieuwe stallen zijn groot en ruim van opzet. De traditionele afdelingsgrootte van 40 - 80 dieren / afdeling wordt losgelaten en tendeert nu naar 250 - 400 kalveren per afdeling. De stallen zijn goed geïsoleerd en voorzien van mechanische ventilatie, gestuurde luchtinlaat, met toepassing van ruimte- en roosterverwarming (CV) tijdens de opstartfase en volautomatische melkverstrekking. Emissiereductie wordt tot op heden nauwelijks toegepast, maar wordt vanaf 2018 verplicht. Op dit moment voldoen alleen luchtwassystemen aan de reductie-eisen. Het systeem van V-vormige mestbanden onder de roosters, om mest en urine direct te scheiden en regelmatig uit de stal af te voeren, oogt perspectiefvol. De stal is in de regel het brandcompartiment.

De ontwikkeling naar vleeskalveren in grote groepen (Peter's Farm) zet niet door en is op z'n retour. 5 - 8 kalveren per hok gehouden op een volledig roostervloer lijkt het meest renderend. Door de kwaliteitskeurmerken (Beter Leven) zal de druk toenemen op het verbeteren van dierenwelzijnsaspecten, zoals het gebruik van zachte roostervloeren i.p.v. hardhout, gebruik van ruwvoer (nu ook al in bepaalde mate verplicht) en daglichttoetreding.

De technische installaties kunnen goed worden ondergebracht in een aparte technische ruimte, tevens voerkeuken. Deze maakt nog vaak onderdeel uit van de stal, maar zou ook losgeplaatst kunnen worden. Vanwege het aanlengen en verstrekken van kalvermelk is er een constante en aanzienlijke behoefte aan stroom en warm water. Een deel van de bedrijven maakt gebruik van hout(snipper)gestookte CV, zonnepanelen en zonnecollectoren. 
Blankvleesproductie vindt vooral op contractbasis plaats, waarbij de kalverhouder vanuit de integraties een vergoeding krijgt voor de verzorging van de kalveren. Contracten hebben veelal een looptijd van 3 mestronden.

Bij de jong- en oud roséproductie vindt men veelal vaak verschillende leeftijdsgroepen op het bedrijf. Deze worden in aparte stallen (of aparte afdelingen binnen een stal) gescheiden van elkaar gehuisvest. De stallen zijn minder gesloten en eenvoudiger van opzet dan bij blankvlees, het voer (een mengsel van krachtvoer, snijmais en enkelvoudige grondstoffen/bijproducten) wordt met behulp van een voermengwagen aan het voerhek verstrekt. Er is weinig techniek in de stallen (alleen verlichting en in toenemende mate mechanische ventilatie). De inrichting is vooral beton en ijzer. Er vindt geen stroverstrekking plaats. Voor de rosé-kalveren gaan dezelfde emissiereductie-eisen gelden als bij blankvlees. Met de huidige beschikbare systemen zal dit tot een toename van het gebruik van luchtwassers leiden.

De gebruikelijke groepsgrootte ligt tussen 10 en 15 kalveren per hok. Ook hierin is geen verandering te verwachten.

Rosékalveren worden in de regel voor eigen kosten en risico gehouden en vaak geleverd aan de slachterij die op dat moment het meeste biedt.

\section{Varkenshouderij}

Afzetmarkt voor concept-vlees is vooral een Nederlandse markt en deze lijkt richting verzadiging te gaan.

Bedrijven die aan de stoppersregeling (van de ammoniakregelgeving) hebben deelgenomen zullen uiterlijk 2020 hun activiteiten staken. Aandacht voor Voormalige Agrarische Bebouwing (VAB's). Deze lege stallen bevatten weliswaar geen dieren meer, maar vormen vaak wel een extra risico voor het ontstaan van brand omdat ze in de regel slecht of niet worden onderhouden.

Varkenshouderij zal groot deel van geproduceerde mest verwerken. I.t.t. legpluimvee gebeurt dit niet op het bedrijf, maar in centrale verwerkingsinstallaties. Soms vindt wel een voorscheiding plaats op het bedrijf met behulp van een mobiele mestscheider die tijdelijk op het varkensbedrijf wordt geplaatst.

De schaalvergroting in de varkenssector zet door. Bedrijven an sich worden groter, met inzet van vreemd personeel. Zeugenbedrijven tenderen geleidelijk naar een omvang van 1000 zeugen of meer. Vleesvarkens op locaties van 3000 dieren of meer, vaak meerdere locaties per ondernemer, met alleen toezicht tijdens de dagelijkse controle. Afdelingsgroottes nemen navenant toe, tot wel 500 vleesvarkensplaatsen per afdeling. Als gevolg van kwaliteitsconcepten is er een voorzichtige trend naar $1 \mathrm{~m} 2$ per dier en houderij in grotere groepen (20 of 40+), al dan niet met toepassing van een tweede leefniveau (plateaustal). Grote groepen (10\% reductie van het benodigde leefoppervlak) en plateaustallen maken dat de dierdichtheid per vierkante meter staloppervlak kan gaan toenemen in plaats van de verwachte afname als gevolg van een groter leefoppervlak.

Het emissiearme systeem in de varkenshouderij is de (combi-)luchtwasser. Het nieuwe Besluit emissiearme huisvesting laat ook weinig ruimte voor andere emissiearme technieken. Hierdoor worden weer (diepe) mestkelders gebouwd met langdurige opslag van mest in de stal. Als gevolg hiervan en mogelijk in combinatie met het voeren van minder goed verteerbare eiwitten, zien we vooral in de nawinter veel schuimvorming in de mestputten (tot boven de roosters). Dit schuim bestaat uit schadelijke en brandbare gassen en vormt een direct risico voor brand in geval van bv laswerkzaamheden of andere vonkbronnen.

Een ander neveneffect van het gebruik van luchtwassers en van de wens tot besparen op energieverbruik (elektra, verwarming) is dat er minder wordt geventileerd en het interne stalklimaat verslechtert. De stallucht wordt bedompter en vochtiger. Hoge RV (relatieve luchtvochtigheid) en ammoniakconcentraties vormen een extra risico voor corrosie aan elektrische installaties (verlichting, stopcontacten, elektromotoren). Een indirect risico voor brand.

Om flexibel te zijn en te blijven voor toekomstige renovaties, worden staldaken uitgevoerd met een vrije overspanning. Als gevolg hiervan hebben de afdelingswanden geen constructieve of dragende functie meer en worden ze vrijwel standaard uitgevoerd met kunststof panelen. Deze hebben als voordelen dat ze glad afgewerkt, goed reinigbaar en licht van kleur zijn, en snel en eenvoudig te plaatsen. Er is discussie over in hoeverre deze wanden moeten voldoen aan de eisen van het Bouwbesluit. 
Bij vleesvarkens is het ventilatieplafond op $z^{\prime} n$ retour. De praktijk kiest in toenemende mate voor stallen met veel inhoud en luchtaanvoer via grondkanalen. Plafondventilatie wordt nog wel veel toegepast bij kraamzeugen en gespeende biggen.

In de varkenshouderij zijn technische installaties goed te concentreren in een aparte technische ruimte. De elektrische systemen in de dierverblijven zelf zijn beperkt tot de aansturing van voerventielen, de diafragma- of smoorklep voor de ventilatie en de verlichting. Er wordt in toenemende mate gebruik gemaakt van daglicht en TL-verlichting op LED-basis.

De technische resultaten in de zeugenhouderij hebben het afgelopen decennium een enorme sprong gemaakt. Bedrijven die ruim 30 biggen per zeug per jaar produceren, vormen geen uitzondering meer. Hierdoor kan op veel bedrijven krapte aan biggenopfokruimte ontstaan. De technische resultaten in de vleesvarkenshouderij blijven stabiel.

\section{Leghennen}

Eén van de uitdagingen waar de leghennensector voor staat de komende jaren is het terugdringen van de emissie van fijnstof. Met daarnaast een verdere verlaging van de emissies van ammoniak en ook geur. De afgelopen jaren is de sector nagenoeg volledig overgegaan van kooi-huisvesting naar alternatieve huisvesting. Nadat het verbod om de verrijkte kooien is ingegaan zullen nog enkele bedrijven dieren in zogenaamde Koloniehuisvesting blijven houden. De zogenaamde scharrelhuisvesting (stal met een enkele laag roostervloer met daaronder opslag van mest) zal ook sterk verminderen. Dit laatste vanwege de hogere ammoniakemissie en daarnaast het economisch aantrekkelijk er zijn van volièrehuisvesting (meer dieren per $\mathrm{m} 2$ staloppervlak). Vanwege de aanwezigheid van mestbanden voor het afvoeren van de mest is er in een volièrestal meer risico op ontstaan van brand (aandrijfmotoren in de dierruimte), maar ook op snelle uitbreiding.

Om aan de eis van reductie fijnstof te kunnen voldoen zullen technieken moeten worden ontwikkeld. Het opnemen van de strooiselschuif (realiseren van een dunne laag strooisel) in de regelgeving, met $20 \%$ reductie, is een voor de praktijk belangrijke stap. Mede omdat deze techniek ook bijdraagt aan het voorkomen van buitennesteieren. Aanvullende technieken zoals ionisatie in de stal maar ook behandeling van de uitgaande lucht (luchtwassers) zullen nodig zijn om aan de doelstellingen van de overheid te kunnen voldoen (minimaal $30 \%$ reductie bij nieuwe stallen).

Een van de oplossingsrichtingen is het toepassen van een droogtunnel. Naast het effect op de mestafzetkosten geeft deze techniek een reductie van de fijnstofemissie van 30 of 55\%, afhankelijk van de uitvoering. Uit onderzoek blijkt echter dat de extra ammoniakemissie uit de tunnel hoger is dan tot nu toe werd aangenomen. Ook geeft de toepassing een extra geuremissie, iets waar nu in de regelgeving geen rekening mee wordt gehouden. Naar aanleiding van deze waarnemingen is er nu vraag naar de mogelijkheden, met bijbehorende emissies, van de combinatie van niet meer voordrogen in de stal en de mest binnen 24 uur in een droogtunnel te brengen waar ze wordt gedroogd tot minimaal $80 \%$ drogestof.

Een andere uitdaging voor de sector is het niet meer mogen behandelen van de snavels. Om beschadigend pikgedrag (of kannibalisme) te voorkomen wordt o.a. gekeken naar de mogelijkheden van LED-verlichting. Met LED-verlichting is het mogelijk om het spectrum aan te passen aan de wensen van de kip. Alleen is (nog) niet bekend wat het spectrum moet zijn.

Alle bovengenoemde ontwikkelingen zullen gepaard gaan met meer elektrisch aangedreven apparatuur in of naast de stal. En daarmee ook met een toename van kans op elektrische storingen gevolgd door brand. Aandacht van de ontwikkelaars van de technieken voor dit aspect is dan ook iets waar op gelet moet worden.

De ontwikkeling van de afgelopen jaren naar het toepassen van een vrije uitloop staat ter discussie vanwege de uitbraken met vogelgriep. Een verdere toename van de productie volgens deze eisen zal waarschijnlijk beperkt zijn. Binnen de leghennensector worden verder weinig specifieke 'eigen' concepten ontwikkeld.

\section{Vleeskuikens}

In de vleeskuikensector is de overgang naar het houden van de dieren volgens een van de concepten nog gaande. Afhankelijk van in welke mate afzet voor het product ook in het buitenland kan worden gevonden, zullen bedrijven nog omschakelen. Inschatting is dat nu ca. $25-30 \%$ van het aantal dieren volgens een van de concepten worden gehouden. Bij deze concepten is de aanwezigheid van een overdekte uitloop, naast de eisen voor lagere bezetting, tragere groei en aanwezigheid van daglicht, een belangrijk aspect. Niet bij alle concepten wordt de overdekte uitloop geëist. Een discussie die de 
komende jaren mogelijk gaat spelen is in hoeverre kunstmatig daglicht (d.m.v. LED-verlichting) wordt geaccepteerd als vervanger van werkelijk daglicht (via dakplaten, lichtkokers of ramen). De omschakeling naar het houden van vleeskuikens volgens een van de concepten brengt op zich geen extra risico's met zich mee ten aanzien van het ontstaan van brand.

Een andere ontwikkeling is die van het laten uitkomen van eieren in de stal. De eieren komen op dag 18 van het broedproces op het vleeskuikenbedrijf. De meest bedrijven laten de kuikens na het uitkomen in de stal, een enkeling (tot nu toe) verplaatst de dieren na ca 10 dagen naar een andere stal. Voordeel van dit laatste is dat er op jaarbasis meer dieren kunnen worden afgeleverd. Voor het uitkomen in de stal zijn verschillende technieken beschikbaar. Van een eenvoudig systeem met kartonnen dozen (One2Born, met veel handwerk) tot een oplierbaar systeem waarin de uitbroedlades worden geplaatst (X-Treck). Het systeem met uitbroedlades kan ook worden toegepast in een etagesysteem. In dit systeem worden de kuikens gehouden op een mestbanden met daarop strooisel. In een stelling zijn meerdere mestbanden boven elkaar gesitueerd. Het in de stal brengen van meer techniek (en elektromotoren) geeft een groter risico op het ontstaan van brand.

Ook de vleeskuikenhouderij wordt geconfronteerd met de eis van reductie van emissies van fijnstof, ammoniak en geur. Voor de reductie van ammoniak zijn al veel technieken beschikbaar, maar voor fijnstof en vooral geur is nog veel onderzoek en ontwikkeling nodig. Het liefst van technieken die een bijdrage leveren aan het verbeteren van het stalklimaat. Ook hier geldt dat een toename van techniek in de stal ook meer risico op brand meebrengt. 


\section{Bijlage 6 Interpretatie regelgeving}

Er blijkt in de praktijk nog op een aantal terreinen onduidelijkheid te zijn over de juiste interpretatie en toepassing van de bouwregelgeving bij zowel nieuw te bouwen stallen als bij bestaande stallen. Deze onduidelijkheden leiden soms tot onjuiste toepassingen en daarmee tot een lager niveau van brandveiligheid dan de wetgever heeft beoogd. Deze onduidelijkheden komen met name tot uiting bij het toepassen van gelijkwaardigheid en bij het uitbreiden van bestaande stallen. In de interviews werden zorgen geuit over de verschuiving van de bouwplantoets van het publieke naar het private domein. In een interview werd ook de mogelijkheid geopperd van gebruiksmelding voor (grote) veestallen. Dit hoofdstuk gaat voor de genoemde onderwerpen in op de bestaande situatie c.q. op toekomstige ontwikkelingen met betrekking tot regelgeving.

\section{Gelijkwaardigheid}

NEN6060 (2015) en NEN6079 (2016) geven bepalingsmethoden om op een aan het Bouwbesluit 2012 gelijkwaardige wijze de grootte van een brandcompartiment te bepalen. NEN6060 vervangt de tot 2015 gebruikte bepalingsmethode 'Beheersbaarheid van Brand'. Verschil met NEN6060 is dat NEN6079 de gelijkwaardigheid baseert op risicobenadering en fysische brandmodellering.

De normen en de toelichting daarbij geven aan dat toepassing van de normen niet is bedoeld om af te wijken van de eisen die het Bouwbesluit 2012 stelt ter voorkoming van dierenleed bij brand in dierenverblijven. Dat wil zeggen dat als de grootte van een brandcompartiment wordt bepaald op basis van NEN 6060 (of NEN 6079), het brandcompartiment waarin de dieren verblijven niet groter mag zijn dan $2.500 \mathrm{~m}^{2}$. Hiermee is getracht te regelen dat de beide normen niet gebruikt worden voor dierenverblijven. Dat blijkt ook uit het feit dat er in beide normen niets staat over het wel of niet meerekenen van levende have als vuurlast. Omdat er in de norm staat 'het gedeelte bestemd als dierenverblijf kan maximaal $2.500 \mathrm{~m}^{2}$ beslaan' en niet 'het brandcompartiment waarin het dierenverblijf is gelegen kan maximaal $2.500 \mathrm{~m}^{2}$ beslaan', wordt er in de praktijk nog wel eens een gebruik gemaakt van deze veronderstelde maas in de regeling. Er wordt in die gevallen alleen gekeken of het strikte oppervlakte waar de dieren staan kleiner is dan $2.500 \mathrm{~m}^{2}$, waarbij loop/voerpaden voor dierverzorgers niet worden meegerekend. Omdat ook gemeenten soms mee gaan in deze redenering worden er toch dierenverblijven gebouwd die groter zijn dan $2.500 \mathrm{~m}^{2}$. In die gevallen speelt dan ook de discussie of levende have moet worden meegerekend als vuurbelasting, aangezien de norm daar niets over zegt.

\section{Toepassing NEN 6060 en 6079 voor dierenverblijven}

Beide normen worden uitgebreid met een bijlage waarin een bepalingsmethode is opgenomen waarmee kan worden bepaald of, gebruikmakend van het gelijkwaardigheidsbeginsel, bij dierenverblijven een groter brandcompartiment mogelijk is. Bij de totstandkoming van deze bijlage bij NEN 6060 wordt rekening gehouden met de resultaten uit het 'Onderzoek naar brandveiligheid voor dieren in veestallen - knelpunten en verbetermogelijkheden' van Wageningen UR Livestock Research en het Instituut Fysieke Veiligheid uit november 2012 en de brandweerstatistieken van Brandweer Nederland uit de periode [2012 tot 2016]. Het streven van NEN is dat beide bijlagen nog in 2017 worden toegevoegd aan de normen. De beide normen worden in de opvolger van het Bouwbesluit 2012, het besluit Bouwen Leefomgeving (inwerkingtreding 2019), aangewezen. Gemeenten blijven in de toekomst de mogelijkheid houden om een aangetoonde gelijkwaardigheid goed te keuren ook zonder dat de vergunningaanvrager de bijlage voor veestallen bij de NEN-normen toepast.

\section{Eisen bij uitbreiding bestaande stal}

Uit de interviews blijkt dat er onduidelijkheid bestaat over toepassing van de bouwregelgeving bij uitbreiding van een bestaande stal. Volgens het Bouwbesluit 2012 is verbouw het geheel of gedeeltelijk vernieuwen of veranderen of het vergroten van een bouwwerk. Als een bestaand dierenverblijf wordt uitgebreid valt dit onder de regels voor verbouw. In beginsel moet de uitbreiding voldoen aan het actuele niveau van het bestaande deel (het zogenaamde rechtens verkregen niveau, 
mits legaal gebouwd). Als dit niveau hoger is dan het niveau dat geldt voor nieuwbouw, mag het uitgebreide gedeelte voldoen aan de regels bij nieuwbouw. Als het actuele niveau van het bestaande deel lager ligt dan het niveau voor bestaande bouw dan hoeft de uitbreiding alleen aan het bestaande niveau te voldoen. In sommige gevallen geeft het bouwbesluit echter een ondergrens aan voor een uit te breiden gedeelte. Bij dierverblijven is dat gedaan voor de brandvoortplantingsklasse. Bij (onder meer) het vergroten van dierverblijven moet de uitbreiding voldoen aan het bepaalde in artikel 2.67 lid 1 van het Bouwbesluit. En daarin staat dat het binnenoppervlak van een 'lichte industriefunctie, bestemd voor bedrijfsmatig houden van dieren' moet voldoen aan brandklasse B. Deze eis van minimaal brandklasse $\mathrm{B}$ voor het bouwmateriaal geldt dus ook voor de uitbreiding van een bestaand dierverblijf.

\section{Bouwplantoetsing: van publieke naar private toets}

Met de inwerkingtreding van de Wet Kwaliteitsborging voor het Bouwen verschuift de preventieve toets op de plannen en uitvoering van nieuwbouw en verbouw van het bevoegd gezag (de gemeente) naar een private kwaliteitsborger. De bouwwerken zijn daartoe ingedeeld in drie zogenaamde gevolgklassen. Hoe zwaarder de gevolgklasse, d.w.z. hoe groter de mogelijke gevolgen verbonden aan het falen van een bouwwerk, hoe zwaarder de eisen zijn die aan de private kwaliteitsborger worden gesteld en de instrumenten waarmee hij moet werken.

De verschuiving van bevoegd gezag naar private kwaliteitsborger start in 2018 met bouwwerken die vallen in gevolgklasse 1.

Dierverblijven vallen onder gevolgklasse 1 , voor zover het bouwwerk uit niet meer dan twee bouwlagen bestaat en de nevenfuncties voor niet meer dan 10 personen bestemd zijn. Indien bij het bouwen of verbouwen gebruik wordt gemaakt van een gelijkwaardige oplossing, valt het bouwwerk niet onder gevolgklasse 1 en zal toetsing voorlopig nog blijven plaatsvinden door het bevoegd gezag. 


\section{Bijlage 7 Kostenoverzicht brandveiligheidsmaatregelen (2012)}

(Meer-)kosten van brandveilige maatregelen op gebied van huisvesting en techniek (uit: BokmaBakker 2012)

\begin{tabular}{|c|c|c|c|c|c|c|}
\hline Maatregel/voorziening & $\begin{array}{l}\text { Sector van } \\
\text { toepassing }\end{array}$ & $\begin{array}{l}\text { Huisvestings- } \\
\text { systeem }\end{array}$ & $\begin{array}{l}\text { Investerings- } \\
\text { kosten } \\
\text { standaardstal* } \\
\text { (€/dierplaats) } \\
\end{array}$ & $\begin{array}{l}\text { Meerkosten (totaal en } \\
\text { per dierplaats) }\end{array}$ & $\begin{array}{l}\text { Mogelijkheid inbouw } \\
\text { bestaande stallen? } \\
\text { (extra kosten t.o.v. } \\
\text { meerkosten) }\end{array}$ & $\begin{array}{l}\text { Uitgangspunten berekening / typen } \\
\text { materialen/type systeem .. }\end{array}$ \\
\hline $\begin{array}{l}\text { Branddetectiesysteem } \\
\text { in technische ruimte }\end{array}$ & Alle sectoren & & & Ca. $€ 5.000 /$ ruimte & $\mathrm{Ja}$ & $\begin{array}{l}\text { Sensor voor temperatuur, rook of } \mathrm{CO}_{2} \\
\text { gekoppeld aan centrale alarmering (bestaande } \\
\text { infrastructuur zoals klimaat-/voercomputer/ } \\
\text { melkrobot benutten) }\end{array}$ \\
\hline \multirow[t]{9}{*}{$\begin{array}{l}\text { Compartimentering } \\
\text { technische ruimtes: }\end{array}$} & Zeugen/biggen & & $€ 2.600$ & $\begin{array}{l}\text { Ca. } € 9.000 \\
\text { ( } 15 \text { per zeugenplaats) }\end{array}$ & $\begin{array}{l}\text { Lastig } \\
\text { (extra kosten ca. 50\%) }\end{array}$ & $\begin{array}{l}\text { Brandmuur: tot } 2,5 \mathrm{~m} \text { hoog beton }+ \text { daarboven } \\
\text { brandwerende aftimmering (ca. } € 50-100 \text { per } \\
\mathrm{m}^{2} \text { duurder dan standaard binnenmuur). Plus } \\
\text { versteviging kolomconstructie. Totaal } \\
\text { gemiddeld } € 90,-/ \mathrm{m}^{2} \text {. } \\
\text { (Of: brandwerende panelen met } \\
\text { glaswol/steenwol tussenlaag: ca. } € 40 / \mathrm{m}^{2} \text { ) }\end{array}$ \\
\hline & Vleesvarkens & & $€ 425$ & $\begin{array}{l}€ 7.500 \\
(€ 2,00 \text { per dierplaats })\end{array}$ & $\begin{array}{l}\text { Lastig } \\
\text { (extra kosten ca. 50\%) }\end{array}$ & Idem zie boven \\
\hline & Vleeskuikens & & $€ 12,50$ & $\begin{array}{l}€ € 15.000 \\
(€ 0,17 \text { per dierplaats })\end{array}$ & $\begin{array}{l}\text { Lastig } \\
\text { (extra kosten ca. 50\%) }\end{array}$ & Idem zie boven; 2 stallen \\
\hline & Leghennen & Scharrelsysteem & $€ 33,-$ & $\begin{array}{l}€ 10.000 \\
(€ 0,35 \text { per dierplaats })\end{array}$ & $\begin{array}{l}\text { Lastig } \\
\text { (extra kosten ca. } 50 \% \text { ) }\end{array}$ & $\begin{array}{l}\text { Idem zie boven; } 2 \text { stallen (waarvan } 1 \text { met } \\
\text { technische ruimte) }\end{array}$ \\
\hline & & Volièresysteem & $€ 26,50$ & $\begin{array}{l}€ 10.000 \\
(€ 0,25 \text { per dierplaats })\end{array}$ & $\begin{array}{l}\text { Lastig } \\
\text { (extra kosten ca. } 50 \% \text { ) }\end{array}$ & Idem zie boven; 1 stal \\
\hline & & Koloniesysteem & $€ 26,-$ & $\begin{array}{l}€ 12.000 \\
(€ 0,20 \text { per dierplaats })\end{array}$ & $\begin{array}{l}\text { Lastig } \\
\text { (extra kosten ca. } 50 \% \text { ) }\end{array}$ & Idem zie boven; 1 stal \\
\hline & Vleeskalveren & Blankvlees & $€ 1.250$ & $\begin{array}{l}€ 9.000 \\
(€ 9,00 \text { per dierplaats })\end{array}$ & $\begin{array}{l}\text { Lastig } \\
\text { (extra kosten ca. } 50 \% \text { ) }\end{array}$ & Idem zie boven; 1 stal \\
\hline & & Rose & & n.v.t. & & \\
\hline & Melkvee & Ligboxenstal & $€ 4.000$ & $\begin{array}{l}€ 9.000 \\
(€ 90 \text { per dierplaats) }\end{array}$ & $\begin{array}{l}\text { Lastig } \\
\text { (extra kosten ca. 50\%) }\end{array}$ & Idem, 1 stal \\
\hline
\end{tabular}

\begin{tabular}{|c|c|c|c|c|c|c|}
\hline \multirow{4}{*}{$\begin{array}{l}\text { Aparte stalling } \\
\text { voertuigen }\end{array}$} & Varkens & & & & & Nvt \\
\hline & Pluimvee & & & & & Nvt \\
\hline & Vleeskalveren & Rose & & & & Nvt \\
\hline & Melkvee & & & & & Is aanwezig \\
\hline \multirow{5}{*}{$\begin{array}{l}\text { Buitendeuren in alle } \\
\text { brandcompartimenten }\end{array}$} & Zeugen/biggen & & & Ca. $€ 1.000$ per deur & & Zijn doorgaans aanwezig \\
\hline & Vleesvarkens & & & Ca. $€ 1.000$ per deur & & Zijn doorgaans aanwezig \\
\hline & Pluimvee & & & Ca. $€ 1.000$ per deur & & Zijn doorgaans aanwezig. \\
\hline & Vleeskalveren & & & Ca. $€ 1.000$ per deur & & Zijn doorgaans aanwezig \\
\hline & Melkvee & & & Ca. $€ 1.000$ per deur & & Zijn doorgaans aanwezig \\
\hline \multirow{10}{*}{$\begin{array}{l}\text { Dakisolatie ten minste } \\
\text { brandklasse B }\end{array}$} & \multirow[t]{2}{*}{ Zeugen/biggen } & & \multirow[b]{2}{*}{$€ 2.600$} & \multirow{2}{*}{$\begin{array}{l}€ 25.000 \\
(€ 40 \text { per zeugenplaats) }\end{array}$} & \multirow{2}{*}{$\begin{array}{l}\text { Niet praktisch (extra } \\
\text { kosten } 100 \% \text { ) }\end{array}$} & Meerprijs t.o.v. brandklasse $\mathrm{D}$ \\
\hline & & & & & & $\begin{array}{l}\text { Brandklasse B: ca. } € 5 \text { per } \mathrm{m}^{2} \text { duurder. } \\
\text { (Eventueel is een bouwkundige toepassing met } \\
\text { andere bevestiging van bestaande materialen } \\
\text { mogelijk; investering zou hiermee tot } € 2,50 \text { per } \\
\mathrm{m}^{2} \text { beperkt kunnen blijven). (Als dakisolatie is } \\
\text { brandklasse A nagenoeg niet haalbaar omdat } \\
\text { steen- en minerale wol niet in plaatmateriaal } \\
\text { beschikbaar is) }\end{array}$ \\
\hline & Vleesvarkens & & $€ 425$ & $\begin{array}{l}€ 20.000 \\
\text { (€5 per dierplaats) }\end{array}$ & $\begin{array}{l}\text { Niet praktisch (extra } \\
\text { kosten 100\%) }\end{array}$ & \\
\hline & Vleeskuikens & & $€ 12,50$ & $\begin{array}{l}€ 22500 \\
(€ 0,25 \text { per dierplaats })\end{array}$ & $\begin{array}{l}\text { Niet praktisch (extra } \\
\text { kosten } 100 \%)\end{array}$ & \\
\hline & Leghennen & Scharrelsysteem & $€ 33,-$ & $\begin{array}{l}€ 15.000 \\
(€ 0,50 \text { per dierplaats })\end{array}$ & $\begin{array}{l}\text { Niet praktisch (extra } \\
\text { kosten } 100 \% \text { ) }\end{array}$ & \\
\hline & & Volieresysteem & $€ 26,50$ & $\begin{array}{l}€ 12.000 \\
(€ 0,30 \text { per dierplaats })\end{array}$ & $\begin{array}{l}\text { Niet praktisch (extra } \\
\text { kosten } 100 \% \text { ) }\end{array}$ & \\
\hline & & Koloniesysteem & $€ 26,-$ & $\begin{array}{l}€ 12500 \\
(€ 0,20 \text { per dierplaats })\end{array}$ & $\begin{array}{l}\text { Niet praktisch (extra } \\
\text { kosten 100\%) }\end{array}$ & \\
\hline & Vleeskalveren & Blankvlees & $€ 1.250$ & $\begin{array}{l}€ 12.000 \\
(€ 12 \text { per dierplaats })\end{array}$ & $\begin{array}{l}\text { Niet praktisch (extra } \\
\text { kosten 100\%) }\end{array}$ & \\
\hline & & Rose & $€ 1.000$ & $\begin{array}{l}€ 8.500 \\
(€ 14 \text { per dierplaats) }\end{array}$ & $\begin{array}{l}\text { Niet praktisch (extra } \\
\text { kosten } 100 \% \text { ) }\end{array}$ & Soms dakisolatie \\
\hline & Melkvee & Ligboxenstal & $€ 4.000$ & $\begin{array}{l}€ 8.000 \\
(€ 80 \text { per dierplaats })\end{array}$ & $\begin{array}{l}\text { Niet praktisch (extra } \\
\text { kosten } 100 \% \text { ) }\end{array}$ & Soms dakisolatie \\
\hline $\begin{array}{l}\text { Plafondisolatie ten } \\
\text { minste klasse B }\end{array}$ & & & & & & $\begin{array}{l}\text { Alleen bij kraamzeugen en gespeende biggen } \\
\text { verlaagd plafond ; in ca. } 60 \% \text { van de stal } \\
\text { mogelijk }\end{array}$ \\
\hline & Zeugen/biggen & & $€ 2.600$ & $\begin{array}{l}€ 9.000 \\
(€ 15 \text { / dierplaats }) \\
€ 15.000 \\
(€ 25,- \text { per dierplaats })\end{array}$ & Ja (extra kosten 25\%) & $\begin{array}{l}\text { Brandklasse B: meerprijs ca. } € 5 / \mathrm{m}^{2} \\
\text { (Bij een verlaagd plafond is ook brandklasse A } \\
\text { haalbaar: damwandprofielplaat met losse } \\
\text { glaswoldeken er op; meerprijs t.o.v. Dupanel } \\
\text { ca. } € 7-10 / \mathrm{m}^{2} \text { ). }\end{array}$ \\
\hline & Vleesvarkens & & & & & Verlaagd plafond nog maar weinig toegepast \\
\hline & Vleeskuikens & & & & & Verlaagd plafond nooit toegepast \\
\hline
\end{tabular}




\begin{tabular}{|c|c|c|c|c|c|c|}
\hline & Leghennen & & & & & Verlaagd plafond nooit toegepast \\
\hline & Vleeskalveren & & & & & Verlaagd plafond nooit toegepast \\
\hline & Melkvee & & & & & Verlaagd plafond nooit toegepast \\
\hline \multirow[t]{9}{*}{$\begin{array}{l}\text { Stal-/hokinrichting } \\
\text { brandklasse B }\end{array}$} & Zeugen/biggen & & $€ 2.600$ & $\begin{array}{l}€ 15.000 \\
(€ 25 \text { per zeugenplaats) }\end{array}$ & Ja (extra kosten 50\%) & $\begin{array}{l}\text { In plaats van gewone kunststof } \\
\text { afdelingswanden (klasse D) zijn er kunststof } \\
\text { wandpanelen met brandklasse B. Meerkosten } \\
\text { ca. } € 5 \text {,- per } \mathrm{m}^{2} \text {. }\end{array}$ \\
\hline & Vleesvarkens & & $€ 425$ & $\begin{array}{l}€ 20.000 \\
(€ 5,- \text { per dierplaats })\end{array}$ & & Idem \\
\hline & Vleeskuikens & & & n.v.t. & & \\
\hline & Leghennen & Scharrelsysteem & & n.v.t. & & $\begin{array}{l}\text { Hardhoutenroosters i.p.v. kunststof geen optie } \\
\text { vanuit hygiëne oogpunt. Gaan er ook steeds } \\
\text { meer uit en ook de vraag of ze } \\
\text { brandvertragend zijn, aangezien het bij } \\
\text { pluimvee om dunne latjes gaat. }\end{array}$ \\
\hline & & Volièresysteem & & & & Idem \\
\hline & & Koloniesysteem & & & & Roosters \\
\hline & Vleeskalveren & Blankvlees & & & & $\begin{array}{l}\text { In het algemeen wordt roestvrij staal } \\
\text { (hokinrichting) toegepast met hardhouten } \\
\text { roosters. Is hoog brandwerend: houten } \\
\text { roosters vatten ook geen vlam. }\end{array}$ \\
\hline & & Rose & & & & $\begin{array}{l}\text { Bovenstaande geldt hier nog nadrukkelijker; } \\
\text { i.p.v. houten roosters hier beton. }\end{array}$ \\
\hline & Melkvee & Ligboxenstal & & & & $\begin{array}{l}\text { Gegalvaniseerd staal; matten in ligboxen wel } \\
\text { brandgevoelig }\end{array}$ \\
\hline $\begin{array}{l}\text { Mesttransportbanden } \\
\text { brandklasse B }\end{array}$ & & & & n.v.t. & & Zijn niet verkrijgbaar \\
\hline $\begin{array}{l}\text { Eiertransportbanden } \\
\text { brandklasse B }\end{array}$ & & & & n.v.t. & & Zijn niet verkrijgbaar \\
\hline \multirow[t]{4}{*}{ Brandslanghaspel } & Leghennen & & $\begin{array}{l}€ 26-33 \text { per } \\
\text { dierplaats }\end{array}$ & $\begin{array}{l}€ 2500 \\
(€ 0,05-0,10 \text { per } \\
\text { dierplaats })\end{array}$ & $\mathrm{Ja}$ & $\begin{array}{l}\text { RVS met } 30 \text { m. slang: } € 400+€ 200 \text { omkasting. } \\
\text { Bij leghennen langs beide zijgevels nodig } \\
(2 \times 2) \text {. }\end{array}$ \\
\hline & Vleeskuikens & & $€ 12,50$ & $\begin{array}{l}€ 2500 \\
(€ 0,03 \text { per dierplaats })\end{array}$ & $\mathrm{Ja}$ & Per stal 2 nodig $(2 \times 2)$ \\
\hline & Zeugen/biggen & & $€ 2.600$ & $\begin{array}{l}€ 3.500 \\
(€ 6,- \text { per dierplaats })\end{array}$ & $\mathrm{Ja}$ & $\begin{array}{l}\text { Varkensstal om de } 4 \text { afdelingen bij centrale } \\
\text { gang; } 6 \text { nodig }\end{array}$ \\
\hline & Vleesvarkens & & $€ 425$ & $\begin{array}{l}€ 2500 \\
(€ 0,60 \text { per dierplaats })\end{array}$ & $\mathrm{Ja}$ & 4 \\
\hline $\begin{array}{l}\text { Aanleg } \\
\text { bluswatervoorziening }\end{array}$ & & & & $€ 10.000$ & $\mathrm{Ja}$ & $\begin{array}{l}\text { Kosten indien puls met voldoende capaciteit } \\
\text { moet worden aangelegd. } \\
\text { Geen kosten indien openbare voorziening of } \\
\text { voldoende oppervlaktewater aanwezig is. } \\
\text { Kosten kunnen lager zijn indien (tevens) } \\
\text { gebruik kan worden gemaakt van } \\
\text { infiltratievijvers om regenwater op te vangen } \\
\text { (bij veel nieuwe bedrijven aanwezig). }\end{array}$ \\
\hline
\end{tabular}




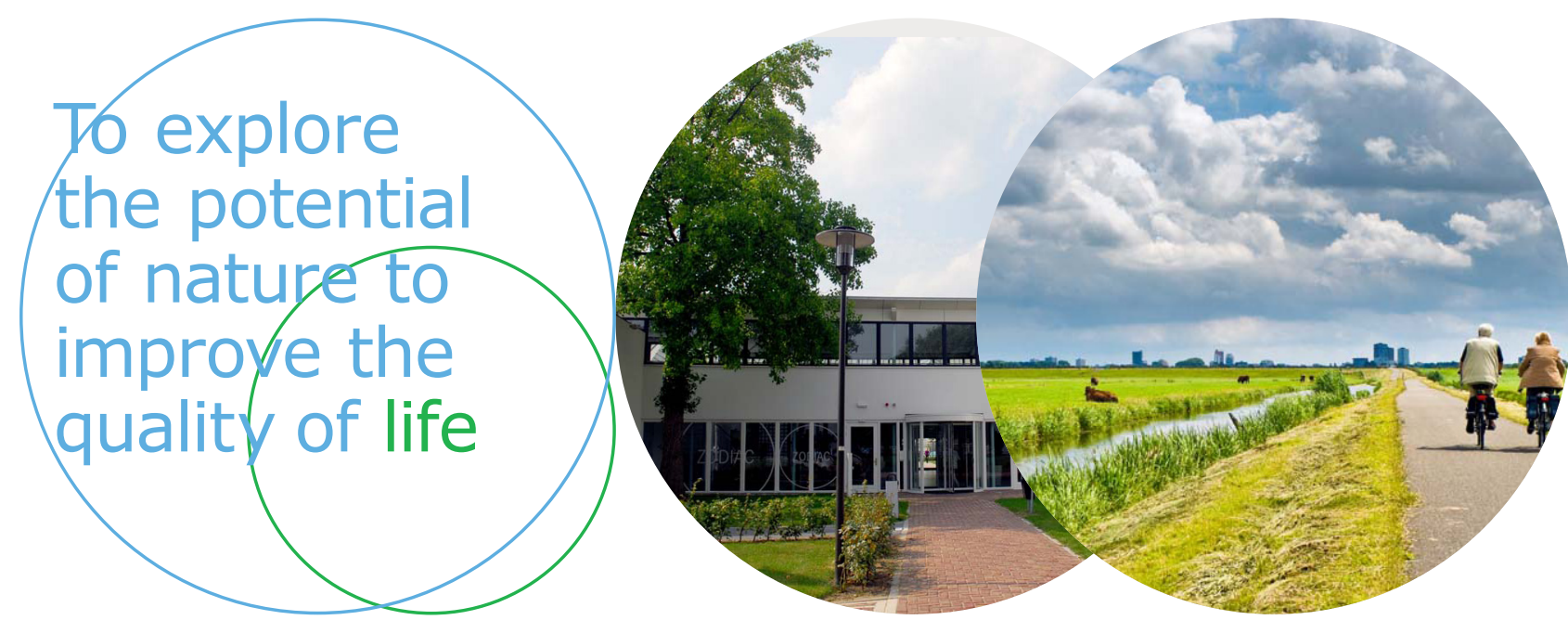

Wageningen Livestock Research Postbus 338

Wageningen Livestock Research ontwikkelt kennis voor een zorgvuldige en $6700 \mathrm{AH}$ Wageningen

T 0317483953

E info.livestockresearch@wur.nl www.wur.nl/ livestock-research renderende veehouderij, vertaalt deze naar praktijkgerichte oplossingen en innovaties, en zorgt voor doorstroming van deze kennis. Onze wetenschappelijke kennis op het gebied van veehouderijsystemen en van voeding, genetica, welzijn en milieu-impact van landbouwhuisdieren integreren we, samen met onze klanten, tot veehouderijconcepten voor de $21 \mathrm{e}$ eeuw.

De missie van Wageningen University \& Research is 'To explore the potential of nature to improve the quality of life'. Binnen Wageningen University \& Research bundelen 9 gespecialiseerde onderzoeksinstituten van Stichting Wageningen Research en Wageningen University hun krachten om bij te dragen aan de oplossing van belangrijke vragen in het domein van gezonde voeding en leefomgeving. Met ongeveer 30 vestigingen, 6.500 medewerkers en 10.000 studenten behoort Wageningen University \& Research wereldwijd tot de aansprekende kennisinstellingen binnen haar domein. De integrale benadering van de vraagstukken en de samenwerking tussen verschillende disciplines vormen het hart van de unieke Wageningen aanpak. 